\title{
Literature Review of $\mathrm{PuO}_{2}$ Calcination Time and Temperature Data for Specific Surface Area
}

W. E. Daniel

March 6, 2012

Savannah River National Laboratory

Savannah River Nuclear Solutions, LLC

Aiken, SC 29808

Prepared for the U.S. Department of Energy under

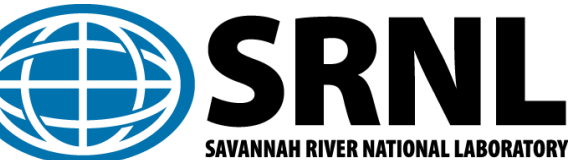
contract number DE-AC09-08SR22470. 
SRNL-TR-2011-00334

Revision 0

\section{DISCLAIMER}

This work was prepared under an agreement with and funded by the U.S. Government. Neither the U.S. Government or its employees, nor any of its contractors, subcontractors or their employees, makes any express or implied:

1. warranty or assumes any legal liability for the accuracy, completeness, or for the use or results of such use of any information, product, or process disclosed; or

2. representation that such use or results of such use would not infringe privately owned rights; or

3. endorsement or recommendation of any specifically identified commercial product, process, or service.

Any views and opinions of authors expressed in this work do not necessarily state or reflect those of the United States Government, or its contractors, or subcontractors.

\section{Printed in the United States of America}

Prepared for

U.S. Department of Energy 
Keywords: $\mathrm{PuO} 2$

Calcination

Specific Surface Area

Retention: Permanent

\section{Literature Review of $\mathrm{PuO}_{2}$ Calcination Time and Temperature Data for Specific Surface Area}

W. E. Daniel

March 6, 2012

Savannah River National Laboratory

Savannah River Nuclear Solutions, LLC

Aiken, SC 29808

Prepared for the U.S. Department of Energy under contract number DE-AC09-08SR22470. 


\section{REVIEWS AND APPROVALS}

\section{AUTHORS:}

W. E. Daniel, Process Technology Programs

Date

TECHNICAL REVIEW:

J. M. Duffey, Separations \& Actinide Science Programs

Date

J. W. Christopher, HB Line Engineering

Date

APPROVAL:

S. D. Fink, Manager

Date

Separations \& Actinide Science Programs

S. L. Marra, Manager

Date

Environmental \& Chemical Process Technology Research Programs

K. P. Burrows, Manager

Date

HB Line Engineering 


\section{ACKNOWLEDGEMENTS}

Jon Duffey of SRNL and John Berg of LANL are thanked for providing a large set of articles for this literature review that dated back to the 1950's and 1960's. 


\section{EXECUTIVE SUMMARY}

The literature has been reviewed in December 2011 for calcination data of plutonium oxide $\left(\mathrm{PuO}_{2}\right)$ from plutonium oxalate $\mathrm{Pu}\left(\mathrm{C}_{2} \mathrm{O}_{4}\right)_{2}$ precipitation with respect to the $\mathrm{PuO}_{2}$ specific surface area (SSA). A summary of the literature is presented for what are believed to be the dominant factors influencing SSA, the calcination temperature and time. The $\mathrm{PuO}_{2}$ from $\mathrm{Pu}\left(\mathrm{C}_{2} \mathrm{O}_{4}\right)_{2}$ calcination data from this review has been regressed to better understand the influence of calcination temperature and time on SSA. Based on this literature review data set, calcination temperature has a bigger impact on SSA versus time. However, there is still some variance in this data set that may be reflecting differences in the plutonium oxalate preparation or different calcination techniques.

It is evident from this review that additional calcination temperature and time data for $\mathrm{PuO}_{2}$ from $\mathrm{Pu}\left(\mathrm{C}_{2} \mathrm{O}_{4}\right)_{2}$ needs to be collected and evaluated to better define the relationship. The existing data set has a lot of calcination times that are about 2 hours and therefore may be underestimating the impact of heating time on SSA. SRNL recommends that more calcination temperature and time data for $\mathrm{PuO}_{2}$ from $\mathrm{Pu}\left(\mathrm{C}_{2} \mathrm{O}_{4}\right)_{2}$ be collected and this literature review data set be augmented to better refine the relationship between $\mathrm{PuO}_{2}$ SSA and its calcination parameters. 


\section{TABLE OF CONTENTS}

LIST OF TABLES $\mathrm{X}$

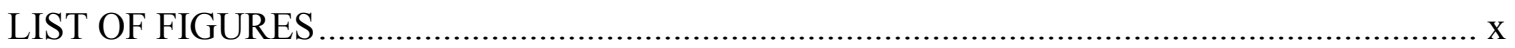

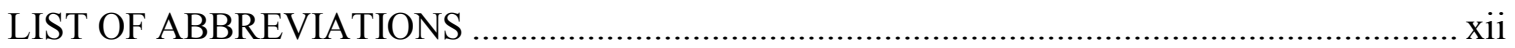

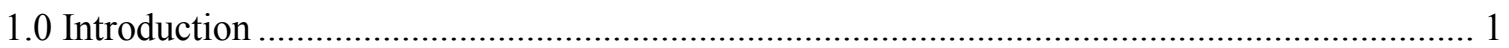

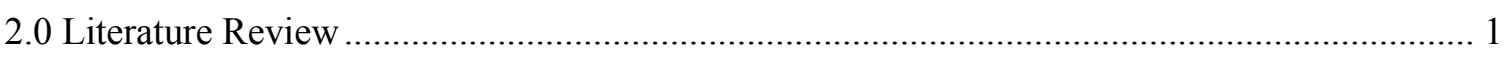

2.1 SRNL Library Website Electronic Searches....................................................................... 1

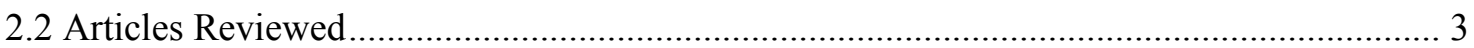

2.2.1 Reference 1: Plutonium dioxide particle properties as a function of calcination

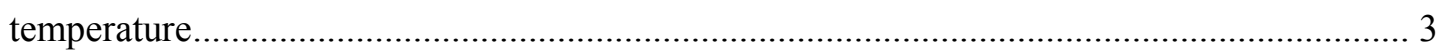

2.2.2 Reference 2: Adsorption of water on plutonium dioxide ............................................. 3

2.2.3 Reference 3: $\mathrm{PuO}_{2}$ Storage: Conditions for Preparation and Handling .......................... 4

2.2.4 Reference 4: Development of Plutonium Bearing Fuel Materials NUMEC P-80 .......... 4

2.2.5 Reference 5: Development of Plutonium Bearing Fuel Materials NUMEC P-90 ......... 4

2.2.6 Reference 6: Effects of Plutonium Dioxide Moisture Content and Calcination Temperature on the Headspace Gas Composition of Sealed Containers ................................. 5

2.2.7 Reference 7: Plutonium Oxide Polishing for MOX Fuel Fabrication............................. 5

2.2.8 Reference 8: Effect of Oxalate Precipitation on $\mathrm{PuO}_{2}$ Microstructures ......................... 6

2.2.9 Reference 9: A critical examination of the thermodynamics of water adsorption on

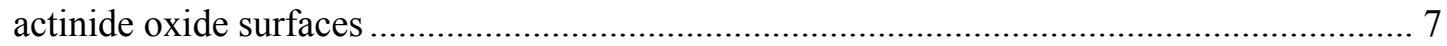

2.2.10 Reference 10: Development of Plutonium Bearing Fuel Materials NUMEC P-100 .... 7

2.2.11 Reference 11: Nanoceria - Energetics of Surfaces, Interfaces and Water Adsorption 7

2.2.12 Reference 12: Technical Basis for Packaging Glovebox Moisture Content ................. 7

2.2.13 Reference 13: Gas Generation from Water Adsorbed onto Pure Plutonium Dioxide

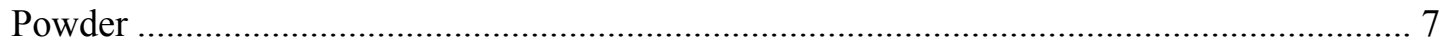

2.2.14 Reference 14: Gas Generation Testing of Plutonium Dioxide.................................... 8

2.2.15 Reference 15: Effect of Precipitation Conditions on the Specific Surface Area of

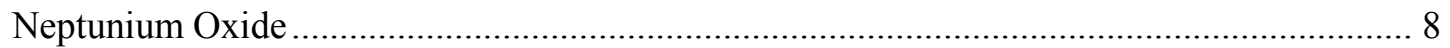

2.2.16 Reference 16: Plutonium Oxide Polishing for MOX Fuel Production........................... 8

2.2.17 Reference 17: Surface Area (BET) and TGA-MS Analysis of Calcined Neptunium Oxide

2.2.18 Reference 18: Moisture and Surface Area Measurements of Plutonium-Bearing Oxides 
2.2.19 Reference 19: Hydration of Plutonium Oxide and Process Salts $\mathrm{NaCl}, \mathrm{KCl}, \mathrm{CaCl}_{2}$, $\mathrm{MgCl}_{2}$

2.2.20 Reference 20: Thermodynamics of Water Sorption on $\mathrm{PuO}_{2}$ : Consequences for Oxide

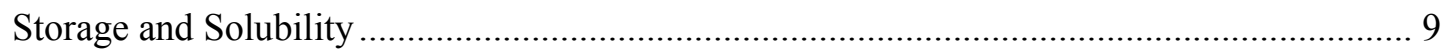

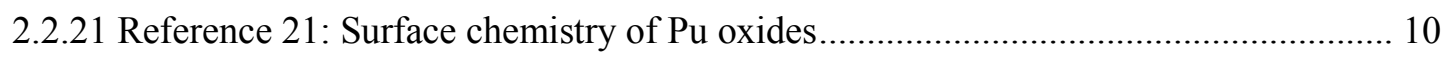

2.2.22 Reference 22: Thermodynamic Data for Hydrous and Anhydrous $\mathrm{PuO}_{2+\mathrm{x}}(\mathrm{s}) \ldots \ldots \ldots \ldots . . . .10$

2.2.23 Reference 23: Calculations of Thermodynamic Properties of $\mathrm{PuO}_{2}$ by the First-

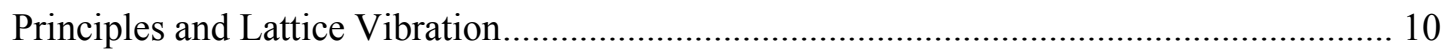

2.2.24 Reference 24: Thermodynamic Modeling of the Plutonium-Oxygen System ............ 10

2.2.25 Reference 25: White Paper on Possible Inclusion of Mixed Plutonium-Uranium

Oxides in DOE-STD-3013-96. 10

2.2.26 Reference 26: Characterization of Representative Materials in Support of Safe, Long Term Storage of Surplus Plutonium in DOE-STD-3013 Containers 10

2.2.27 Reference 27: Characterization of Representative Materials in Support of Safe, Long Term Storage of Surplus Plutonium in DOE-STD-3013 Containers..... 11

2.2.28 Reference 28: Monthly Report Hanford Atomic Products Operation 11

2.2.29 Reference 29: Savannah River Laboratory Monthly Report, ${ }^{238} \mathrm{Pu}$ Fuel Form Processes

2.2.30 Reference 30: Properties of Plutonium Dioxide.

2.2.31 Reference 31: Plutonium(III) Oxalate Precipitation and Calcination Process for Plutonium Nitrate To Oxide Conversion .. 12

2.2.32 Reference 32: Interim Report on Plutonium Oxalate Precipitation Work .................. 12

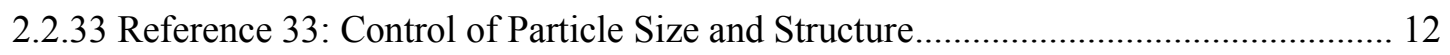

2.2.34 Reference 34: The Thermal Decomposition of Hydrated Plutonium(IV) Oxalates .... 12

2.2.35 Reference 35: Precipitation of Plutonium(III) Oxalate and Calcination to Plutonium

Dioxide. 13

2.2.36 Reference 36: Thermal Decomposition of Plutonium (IV) Oxalate and Hydrofluorination of Plutonium (IV) Oxalate and Oxide 13

2.2.37 Reference 37: Thermal Decomposition of Plutonium Oxalates 13

2.2.38 Reference 38: Determination of Plutonium Dioxide Surface Areas from X-Ray Crystallite Sizes 13

2.2.39 Reference 39: Development of Plutonium-Bearing Fuel Materials, NUMEC-2389-2 13 2.2.40 Reference 40: Development of Plutonium Bearing Fuel Materials, NUMEC-2389-3 14 2.2.41 Reference 41: Development of Plutonium Bearing Fuel Materials, NUMEC-2389-4 14 
SRNL-TR-2011-00334

Revision 0

2.2.42 Reference 42: Irradiation Testing of $\mathrm{UO}_{2}-\mathrm{PuO}_{2}$ Fuels, NUMEC-3432-6 14

2.2.43 Reference 43: Development of Plutonium Bearing Fuel Materials, NUMEC-P-20 ... 14

2.2.44 Reference 44: Development of Plutonium Bearing Fuel Materials, NUMEC-P-34 ... 14

2.2.45 Reference 45: Development of Plutonium Bearing Fuel Materials, NUMEC-P-37 ... 14

2.2.46 Reference 46: Development of Plutonium Bearing Fuel Materials, NUMEC-P-39 ... 14

2.2.47 Reference 47: Development of Plutonium Bearing Fuel Materials, NUMEC-P-40 ... 15

2.2.48 Reference 48: Development of Plutonium Bearing Fuel Materials, NUMEC-P-44 ... 15

2.2.49 Reference 49: Development of Plutonium-Bearing Fuel Materials, NUMEC-P-60 ... 15

2.2.50 Reference 50: Development of Plutonium-Bearing Fuel Materials, NUMEC-P-70 ... 15

2.2.51 Reference 51: Development of Plutonium Bearing Fuel Materials, NUMEC-P-101 . 15

2.2.52 Reference 52: Development of Plutonium Bearing Fuel Materials, NUMEC-P-102 . 16

2.2.53 Reference 53: Development of Plutonium-Bearing Fuel Materials, NUMEC-P-103 . 16

2.2.54 Reference 54: Development of Plutonium-Bearing Fuel Materials, NUMEC-P-104 16

2.2.55 Reference 55: Development of Plutonium Bearing Fuel Materials, NUMEC-P-105 . 16

2.2.56 Reference 56: Development of Plutonium-Bearing Fuel Materials, NUMEC-P-103. 16

2.2.57 Reference 57: Ceramic Properties of $\mathrm{PuO}_{2}$.

2.2.58 Reference 58: Savannah River Laboratory Monthly Report: Pu-238 Fuel Form Process

2.3 Calcination Temperature, Time, and Specific Surface Area Data from Literature Reviewed

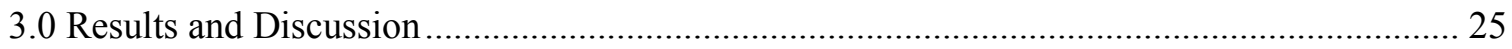

3.1 Preliminary Regression of $250-1100{ }^{\circ} \mathrm{C}$ Calcination and Time Data for $\mathrm{PuO}_{2}$ from

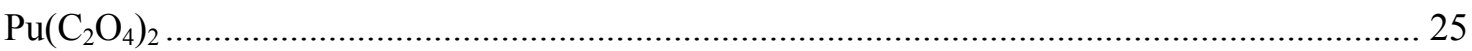

3.2 Preliminary Regression of 550-760 ${ }^{\circ} \mathrm{C}$ Calcination and Time Data for $\mathrm{PuO}_{2}$ from $\mathrm{Pu}\left(\mathrm{C}_{2} \mathrm{O}_{4}\right)_{2}$ 32

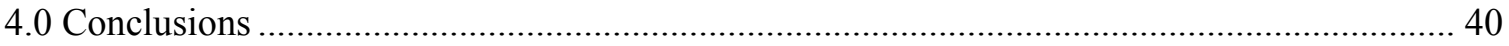

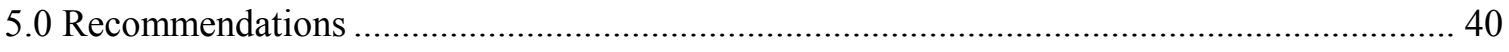

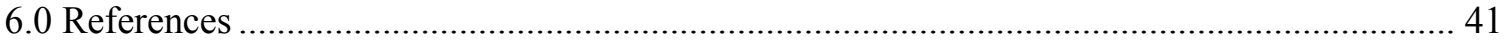




\section{LIST OF TABLES}

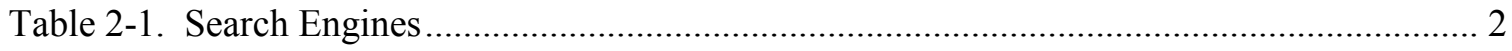

Table 2-2. Estimated Moisture Adsorption for $\mathrm{PuO}_{2}$ Samples $<100$ hours Exposure................... 5

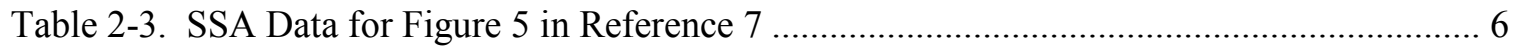

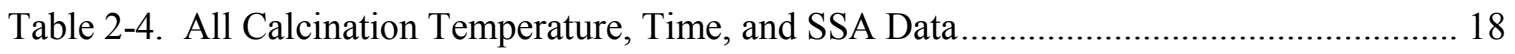

Table 2-5. Calcination Data of $\mathrm{Pu}\left(\mathrm{C}_{2} \mathrm{O}_{4}\right)_{2}$ to $\mathrm{PuO}_{2}$ used for Regression ................................... 22

Table 3-1. Calcination Data of $\mathrm{Pu}\left(\mathrm{C}_{2} \mathrm{O}_{4}\right)_{2}$ to $\mathrm{PuO}_{2}$ for Regression of SSA............................... 26

Table 3-2. Calcination Data $\left(550\right.$ to $\left.760{ }^{\circ} \mathrm{C}\right)$ of $\mathrm{Pu}\left(\mathrm{C}_{2} \mathrm{O}_{4}\right)_{2}$ to $\mathrm{PuO}_{2}$ for Regression of SSA....... 33

Table 3-3. Predicted SSA values of $\mathrm{PuO}_{2}$ from $\mathrm{Pu}\left(\mathrm{C}_{2} \mathrm{O}_{4}\right)_{2}$ at Calcination Temperature $650{ }^{\circ} \mathrm{C}$ for

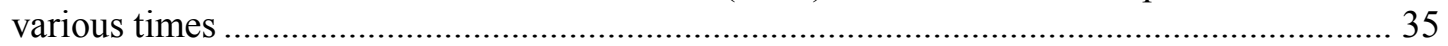

\section{LIST OF FIGURES}

Figure 2-1. $\mathrm{PuO}_{2}$ Specific Surface Area vs Calcination Temperature for References ................ 21

Figure 2-2. $\mathrm{PuO}_{2}$ Specific Surface Area vs Calcination Temperature for Regression ................. 24

Figure 3-1. PuO2 from oxalate-Correlation of SSA to Calcination Temp. $\left(250-1100{ }^{\circ} \mathrm{C}\right)$ and

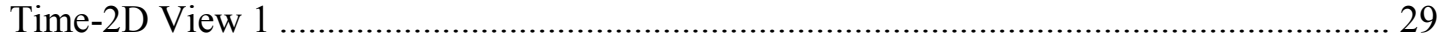

Figure 3-2. $\mathrm{PuO}_{2}$ from oxalate-Correlation of SSA to Calcination Temp. $\left(250-1100{ }^{\circ} \mathrm{C}\right)$ and

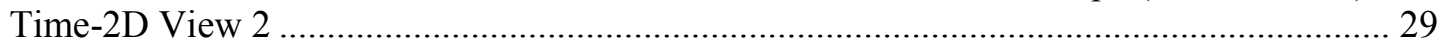

Figure 3-3. $\mathrm{PuO}_{2}$ from oxalate-Correlation of SSA to Calcination Temp. $\left(250-1100{ }^{\circ} \mathrm{C}\right)$ and

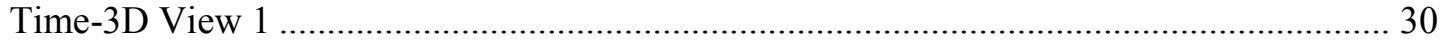

Figure 3-4. $\mathrm{PuO}_{2}$ from oxalate-Correlation of SSA to Calcination Temp. $\left(250-1100{ }^{\circ} \mathrm{C}\right.$ ) and

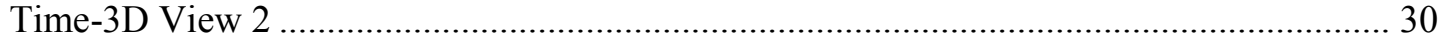

Figure 3-5. $\mathrm{PuO}_{2}$ from oxalate-Correlation of SSA to Calcination Temp. $\left(250-1100{ }^{\circ} \mathrm{C}\right)$ and

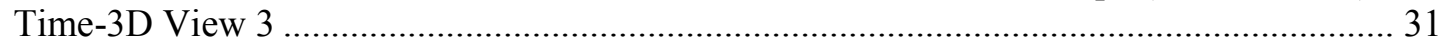

Figure 3-6. $\mathrm{PuO}_{2}$ from oxalate-Correlation of SSA to Calcination Temp. $\left(250-1100{ }^{\circ} \mathrm{C}\right)$ and

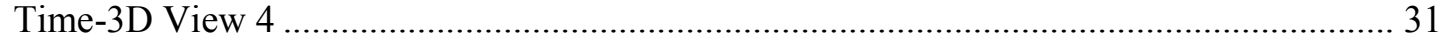

Figure 3-7. $\mathrm{PuO}_{2}$ from oxalate-Correlation of SSA to Calcination Temp. $\left(250-1100{ }^{\circ} \mathrm{C}\right)$ and

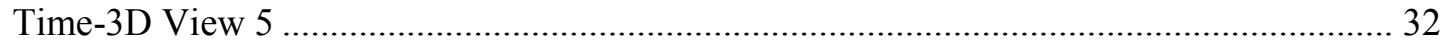

Figure 3-8. $\mathrm{PuO}_{2}$ from oxalate-Correlation of SSA to Calcination Temp. $\left(550-760{ }^{\circ} \mathrm{C}\right)$ and Time2D View 1.

Figure 3-9. $\mathrm{PuO}_{2}$ from oxalate-Correlation of SSA to Calcination Temp. $\left(550-760{ }^{\circ} \mathrm{C}\right)$ and Time-

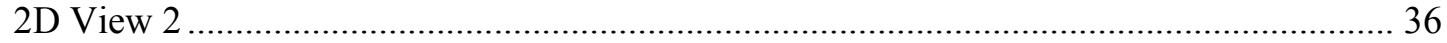


Figure 3-10. $\quad \mathrm{PuO}_{2}$ from oxalate-Correlation of SSA to Calcination Temp. $\left(550-760{ }^{\circ} \mathrm{C}\right)$ and

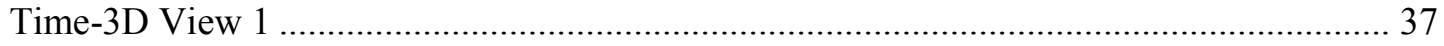

Figure 3-11. $\mathrm{PuO}_{2}$ from oxalate-Correlation of SSA to Calcination Temp. $\left(550-760{ }^{\circ} \mathrm{C}\right)$ and

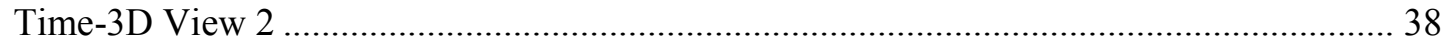

Figure 3-12. $\mathrm{PuO}_{2}$ from oxalate-Correlation of SSA to Calcination Temp. $\left(550-760{ }^{\circ} \mathrm{C}\right)$ and

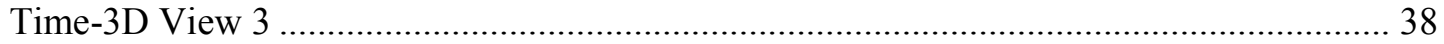

Figure 3-13. $\mathrm{PuO}_{2}$ from oxalate-Correlation of SSA to Calcination Temp. $\left(550-760{ }^{\circ} \mathrm{C}\right)$ and

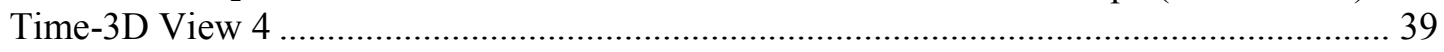

Figure 3-14. $\mathrm{PuO}_{2}$ from oxalate-Correlation of SSA to Calcination Temp. $\left(550-760{ }^{\circ} \mathrm{C}\right)$ and

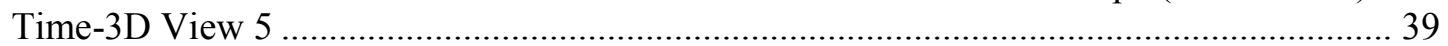




\section{LIST OF ABBREVIATIONS}

$\begin{array}{ll}\text { SRNL } & \text { Savannah River National Laboratory } \\ \text { SSA } & \text { Specific Surface Area } \\ \text { LANL } & \text { Los Alamos National Laboratory } \\ \text { MOX } & \text { Mixed Oxide } \\ \text { LTA } & \text { Lead Test Assembly } \\ \text { SARP } & \text { Safety Analysis Report for Packaging }\end{array}$




\subsection{Introduction}

The literature was reviewed for data concerning the calcination of plutonium(IV) oxalate $\left(\mathrm{Pu}\left(\mathrm{C}_{2} \mathrm{O}_{4}\right)_{2}\right)$ to plutonium oxide $\left(\mathrm{PuO}_{2}\right)$ as it relates to the specific surface area (SSA) of the $\mathrm{PuO}_{2}$ formed. In the following sections, the electronic searches through the SRNL Library website will be explained and then brief descriptions of the various articles will be given. Following the literature summary, all the SSA data found will be identified and then the data most appropriate to correlating to calcination temperature and time will be shown. Finally, some initial correlations to the appropriate SSA data will be given. Note that these initial correlations will be modified or changed as new data is collected or found.

\subsection{Literature Review}

\section{1 $\underline{\text { SRNL Library Website Electronic Searches }}$}

The SRNL Library website electronic search engines were used to look for articles concerning the calcination of plutonium oxalate or like compound as it affects the surface area of the plutonium oxide formed. The key search phrases used in the various search engines were " $\mathrm{PuO}_{2}$ surface area," "Plutonium Oxide surface area," "Plutonium Surface Area," and "Plutonium ceramic fuel preparation." The various search engines used are shown in Table 2-1. Note that the web addresses are not exact but are provided as reference only. 
Table 2-1. Search Engines

\begin{tabular}{|c|c|c|c|}
\hline SRNL Name & Description & Web Name & Web address \\
\hline $\begin{array}{l}\text { Applied Science \& } \\
\text { Technology }\end{array}$ & $\begin{array}{l}\text { Provides abstracts and indexing of } 800 \\
\text { periodicals back to } 1983 \text { and full article texts } \\
\text { from more than } 200 \text { journals back to } 1997 \text {. }\end{array}$ & Wilson Web & $\begin{array}{l}\text { vnweb.hwwilson } \\
\text { web.com }\end{array}$ \\
\hline $\begin{array}{l}\text { Energy Science and } \\
\text { Technology }\end{array}$ & $\begin{array}{l}\text { Formerly DOE ENERGY contains worldwide } \\
\text { references to scientific/technical research for } \\
\text { U.S. Department of Energy from } 1976 \text { on. }\end{array}$ & Dialog Web & $\begin{array}{l}\text { www.dialogweb.c } \\
\text { om }\end{array}$ \\
\hline GeoRef & $\begin{array}{l}\text { GeoRef is the American Geological Institute's } \\
\text { geoscience database containing } 2.4 \text { million } \\
\text { records of North America since } 1785 \text {. }\end{array}$ & OvidSP & $\begin{array}{l}\text { ovidsp.tx.ovid.co } \\
\text { m }\end{array}$ \\
\hline $\begin{array}{l}\text { IEEE - All Society } \\
\text { Periodicals Package }\end{array}$ & $\begin{array}{l}\text { For accessing scientific/technical publications } \\
\text { produced by the Institute of Electrical and } \\
\text { Electronics Engineers (IEEE) from } 1893 \text { on. }\end{array}$ & IEEE Xplore & $\begin{array}{l}\text { ieeexplore.ieee.or } \\
\mathrm{g}\end{array}$ \\
\hline Inspec & $\begin{array}{c}\text { Covers over 5,000 journals from } 1969 \text { to the } \\
\text { present plus } 2,500 \text { conference proceedings and } \\
\text { books, dissertations, patents and reports. }\end{array}$ & EBSCO Host & $\begin{array}{l}\text { web.ebscohost.co } \\
\text { m }\end{array}$ \\
\hline $\begin{array}{l}\text { Intute: Science, } \\
\text { Engineering \& } \\
\text { Technology }\end{array}$ & $\begin{array}{c}\text { Covers the physical sciences, engineering, } \\
\text { computing, geography, mathematics and } \\
\text { environmental science. }\end{array}$ & Intute & www.intute.ac.uk \\
\hline $\begin{array}{l}\text { Materials Research } \\
\text { Database with } \\
\text { Metadex }\end{array}$ & $\begin{array}{l}\text { Contains materials science databases, with } \\
\text { specialist content on materials science, } \\
\text { metallurgy, ceramics, polymers, and } \\
\text { composites used in engineering application. }\end{array}$ & CSA Illumina & $\begin{array}{c}\text { csaweb107v.csa.c } \\
\text { om }\end{array}$ \\
\hline $\begin{array}{l}\text { Materials Research } \\
\text { Society (MRS) On- } \\
\text { line Proceedings } \\
\text { Library }\end{array}$ & $\begin{array}{c}\text { Features over 30,000 peer-reviewed papers } \\
\text { presented at MRS Meetings. }\end{array}$ & Cambridge Journals & $\begin{array}{l}\text { journals.cambridg } \\
\text { e.org }\end{array}$ \\
\hline $\begin{array}{l}\text { National Institute of } \\
\text { Standards \& } \\
\text { Technology Database }\end{array}$ & $\begin{array}{l}\text { Includes scientific, technical, and materials } \\
\text { properties data for chemistry, biotechnology, } \\
\text { law enforcement, mathematical databases, } \\
\text { software, physics and product design. }\end{array}$ & NIST Data Gateway & srdata.nist.gov \\
\hline $\begin{array}{l}\text { National Technical } \\
\text { Reports Library }\end{array}$ & $\begin{array}{l}\text { The National Technical Information Service } \\
\text { acquires, indexes, abstracts, and archives U.S. } \\
\text { government-sponsored technical reports. }\end{array}$ & $\begin{array}{l}\text { National Technical } \\
\text { Reports Library U. S. } \\
\text { Dept. of Commerce }\end{array}$ & ntrl.ntis.gov \\
\hline $\begin{array}{l}\text { Science Citation Index } \\
\text { - Web of Science }\end{array}$ & $\begin{array}{l}\text { Provides access to scientific, technical and } \\
\text { multidisciplinary information from research } \\
\text { journals. }\end{array}$ & $\begin{array}{l}\text { Web of Knowledge-Web } \\
\text { of Science }\end{array}$ & $\begin{array}{l}\text { apps.webofknowl } \\
\text { edge.com }\end{array}$ \\
\hline $\begin{array}{l}\text { Science Interagency } \\
\text { Portal } \\
\end{array}$ & $\begin{array}{c}\text { Includes portals to } 17 \text { scientific/technical } \\
\text { organizations from } 13 \text { federal agencies. }\end{array}$ & USA.gov for Science & www.science.gov \\
\hline $\begin{array}{l}\text { University of } \\
\text { Maryland College } \\
\text { Park Technical } \\
\text { Reports }\end{array}$ & $\begin{array}{c}\text { Includes abstracts, bibliographies, and full-text } \\
\text { technical reports, annual reports, reprints, } \\
\text { preprints, etc. }\end{array}$ & $\begin{array}{l}\text { University of Maryland } \\
\text { Libraries }\end{array}$ & www.lib.umd.edu \\
\hline Worldwide Science & $\begin{array}{l}\text { Site with science information from } 15 \text { national } \\
\text { portals including DOE and the British Library, } \\
\text { along with Australia, Brazil, Canada, } \\
\text { Denmark, France, Germany, Japan and the } \\
\text { Netherlands. }\end{array}$ & World Wide Science & $\begin{array}{l}\text { worldwidescience. } \\
\text { org }\end{array}$ \\
\hline
\end{tabular}


SRNL-TR-2011-00334

Revision 0

\subsection{Articles Reviewed}

The first group of articles reviewed came from Jon Duffey (References 1-17). The next group of articles came from the literature searches discussed in the prior section (References 18-26, 2830). The last set of articles came from John Berg of LANL (References 27, 31-56). The articles will be cited in the order reviewed rather than order of importance or relevancy.

\subsubsection{Reference 1: Plutonium dioxide particle properties as a function of calcination temperature}

This article ${ }^{1}$ contained physical properties of $\mathrm{PuO}_{2}$ powder with respect to the calcination temperature. The physical properties included microcrystal size, particle morphology, and specific surface area. Plutonium(IV) oxalate was precipitated by adding oxalic acid to a $4 \mathrm{M}$ $\mathrm{HNO}_{3}, 8 \mathrm{~g} / \mathrm{L} \mathrm{Pu}(\mathrm{IV})$ solution at $50{ }^{\circ} \mathrm{C}$ for one hour. The precipitate was then digested for another hour at $50{ }^{\circ} \mathrm{C}$, cooled, and then filtered without washing. The initial batch of $\mathrm{PuO}_{2}$ was prepared by firing the $\mathrm{Pu}$ oxalate in air at $450{ }^{\circ} \mathrm{C}$ for 5 hours and then calcined another 5 hours at the various temperatures $\left(450{ }^{\circ} \mathrm{C}\right.$ to $\left.1050{ }^{\circ} \mathrm{C}\right)$. Due to this preparation method the calcination times are treated as a fraction of the initial 5 hours at $450{ }^{\circ} \mathrm{C}$ plus the additional 5 hours at the given temperature. The logic chosen for the calcination time $t_{2}$ for calcination temperature $T_{2}$ is calculated as follows:

$$
t_{2}=\frac{450}{T_{2}} \cdot 5+5
$$

For example, the calcination time for the $650^{\circ} \mathrm{C}, 7.9 \mathrm{~m}^{2} / \mathrm{g}$ data point is treated as 8.46 hours. The $450{ }^{\circ} \mathrm{C}, 12.3 \mathrm{~m}^{2} / \mathrm{g}$ value was not used in the correlation discussed later since the mean for the other $450{ }^{\circ} \mathrm{C}$ data was $39.88 \mathrm{~m}^{2} / \mathrm{g}$ with a standard deviation of 1.04 giving $3 \sigma$ or $99.7 \%$ inclusion limits of 37 to $43 \mathrm{~m}^{2} / \mathrm{g}$. The $550{ }^{\circ} \mathrm{C}, 9.1 \mathrm{~m}^{2} / \mathrm{g}$ value was not used in the model discussed later since the mean for the other $550{ }^{\circ} \mathrm{C}$ data was $35.85 \mathrm{~m}^{2} / \mathrm{g}$ with a standard deviation of $7.42 \mathrm{giving}$ $3 \sigma$ or $99.7 \%$ inclusion limits of 14 to $58 \mathrm{~m}^{2} / \mathrm{g}$ data. The Brunauer-Emmett-Teller (BET) method was used for the surface area measurements. The surface area measurements are shown in Figure 4 in the article.

\subsubsection{Reference 2: Adsorption of water on plutonium dioxide}

This reference ${ }^{2}$ contained kinetic and equilibrium data of the water adsorption onto plutonium dioxide in moist air at room temperature. The article discusses how water is adsorbed by a sequence of distinct steps involving five types of adsorbate-oxide interaction and accumulating ten molecular layers of water (approximately $2.1 \mathrm{mg} \mathrm{H}_{2} \mathrm{O} / \mathrm{m}^{2} \mathrm{PuO}_{2}$ surface) at $100 \%$ relative humidity. Table 1 in this reference contains one specific surface area (by BET) data point of 5.7

$\mathrm{m}^{2} / \mathrm{g}$ at $700{ }^{\circ} \mathrm{C}$ for 12 hours but since this data point originated in reference 3 it will be included with that reference data set. 
SRNL-TR-2011-00334

Revision 0

\subsubsection{Reference 3: $\mathrm{PuO}_{2}$ Storage: Conditions for Preparation and Handling}

This reference ${ }^{3}$ contained desorption and adsorption properties of plutonium dioxide based on production-scale experiments that illustrate how to prepare $\mathrm{PuO}_{2}$ for long-term storage. This article also discusses the conditions for preparing $\mathrm{PuO}_{2}$ to meet Department of Energy standards for safe storage of plutonium. The plutonium is precipitated as plutonium oxalate before calcining to plutonium oxide. The reference is not clear on what reagent was used during precipitation. The BET specific surface area data of interest are in Table 1 and 4 of this reference. For all the data points the calcination temperature and time are given except for the $350{ }^{\circ} \mathrm{C}$ point. For the $350{ }^{\circ} \mathrm{C}$ point, the calcination time is assumed to be 2.1 hour based on the other data reviewed. The calcination time for this data point can be adjusted later should other information become available.

\subsubsection{Reference 4: Development of Plutonium Bearing Fuel Materials NUMEC P-80}

This reference ${ }^{4}$ documents early work for the preparation of $\mathrm{PuO}_{2}$ and $\mathrm{PuO}_{2}-\mathrm{UO}_{2}$ materials. This document contains precipitation and calcination conditions in its Table 2.1 and specific surface area (as well as bulk and tap density, permeability, particle size, and carbon content) data in its Table 2.2. The plutonium oxalate is precipitated by adding $0.8 \mathrm{M} \mathrm{H}_{2} \mathrm{O}_{2}$ to a $3 \mathrm{M} \mathrm{HNO}_{3}, 100 \mathrm{~g} / \mathrm{L} \mathrm{Pu}$ solution followed by $1 \mathrm{M}$ Oxalic Acid at $35^{\circ} \mathrm{C}$ with a hold-up of about 24-25 minutes. The plutonium oxalate cake was washed with deionized water, air dried for 10 minutes, and then calcined in air to plutonium oxide. Both oxalic acid and hydrogen peroxide were used during the precipitation step. All the specific surface area points were used in the empirical regression.

\subsubsection{Reference 5: Development of Plutonium Bearing Fuel Materials NUMEC P-90}

This reference documents early work for the preparation and characterization of $\mathrm{PuO}_{2}$ and $\mathrm{PuO}_{2}-\mathrm{UO}_{2}$ materials. This document contains precipitation and calcination conditions in its Table 2.1 and specific surface area (as well as feed composition, bulk and tap density, permeability, and particle size) data in its Table 2.2. Figure 2.15 in this reference shows for one plutonium oxalate sample the change in SSA with respect to calcination temperature as it is heated continuously in a BET instrument from $100{ }^{\circ} \mathrm{C}$ to $500{ }^{\circ} \mathrm{C}$ holding 20 minutes at each calcination temperature then dropping by $50{ }^{\circ} \mathrm{C}$ and waiting till the SSA stabilized from off-gassing. The reference points out a sudden rise in the surface area at $275{ }^{\circ} \mathrm{C}$ in Figure 2.15 and attributes it to a breakdown in the crystallite structure of the plutonium oxalate caused by fissures forming during crystal structure changes and during the escape of decomposition gases. Figure 2.5 through Figure 2.10 in this reference shows that $90 \%$ of the equilibrium moisture was adsorbed for the $\mathrm{PuO}_{2}$ samples at $33-76 \%$ relative humidity within 6-12 hours and for $97 \%$ relative humidity within 50 hours. This reference also showed that at $97 \%$ relative humidity the $\mathrm{PuO}_{2}$ samples continued to adsorb water for up to 100 hours. This reference stated that at 33-53\% relative humidity the plutonium oxalate calcined at $760{ }^{\circ} \mathrm{C}$ would only adsorb $0.1-0.15 \%$ moisture. Using Figure 2.5 through Figure 2.8, the maximum percent of water adsorbed onto the $\mathrm{PuO}_{2}$ samples for less than 100 hours was estimated as shown in Table 2-2 and the calcination data came from reference 4 of this review. The data indicates that the higher the calcination temperature and the lower the relative humidity, the lower the adsorbed moisture level. The plutonium oxalate for two samples in this reference is precipitated continuously by adding $0.8 \mathrm{M} \mathrm{H}_{2} \mathrm{O}_{2}$ to a $3 \mathrm{M} \mathrm{HNO}, 12-20 \mathrm{~g} / \mathrm{L} \mathrm{Pu}$ solution followed by $1 \mathrm{M}$ Oxalic Acid at $35^{\circ} \mathrm{C}$ with a hold-up of about 20-23 minutes. The plutonium oxalate for the third sample is precipitated in a batch mode by adding $0.8 \mathrm{M} \mathrm{H}_{2} \mathrm{O}_{2}$ to a $3 \mathrm{M} \mathrm{HNO}, 10.5 \mathrm{~g} / \mathrm{L} \mathrm{Pu}$ solution followed by $1 \mathrm{M}$ Oxalic Acid at $55^{\circ} \mathrm{C}$. The plutonium oxalate is then dried at $180^{\circ} \mathrm{C}$ before calcining to plutonium oxide. All the data points in this reference were used in the later empirical regression of the data from the literature review. 
SRNL-TR-2011-00334

Revision 0

Table 2-2. Estimated Moisture Adsorption for $\mathrm{PuO}_{2}$ Samples $<100$ hours Exposure

\begin{tabular}{|c|c|c|c|c|}
\hline \multirow{3}{*}{ Relative Humidity } & \multicolumn{4}{|c|}{ Calcination Data } \\
\cline { 2 - 5 } & Temperature $\left({ }^{\circ} \mathrm{C}\right)$ & 350 & 490 & 760 \\
\cline { 2 - 5 } & Time (h) & 0.58 & 0.08 & 0.08 \\
\cline { 2 - 5 } & ${\mathrm{SSA}\left(\mathrm{m}^{2} / \mathrm{g}\right)}^{2}$ & 57 & 53 & 9.9 \\
\hline $33 \%$ & & $0.80 \%$ & $0.70 \%$ & $0.10 \%$ \\
\hline $53 \%$ & & $1.14 \%$ & $1.00 \%$ & $0.21 \%$ \\
\hline $76 \%$ & & $1.91 \%$ & $1.44 \%$ & $0.54 \%$ \\
\hline $97 \%$ & & $3.80 \%$ & $2.64 \%$ & $1.84 \%$ \\
\hline
\end{tabular}

2.2.6 Reference 6: Effects of Plutonium Dioxide Moisture Content and Calcination Temperature on the Headspace Gas Composition of Sealed Containers

This reference ${ }^{6}$ documents SRNL efforts to develop a model that predicts the gas generation rate and composition of plutonium dioxide materials during long term storage. This document contains specific surface area data in its Figure 4 which came from references 3, 30, and 58 of this review. Therefore, no new specific surface area data from this reference was used in the empirical correlation.

\subsubsection{Reference 7: Plutonium Oxide Polishing for MOX Fuel Fabrication}

This reference ${ }^{7}$ contains data from LANL on the polishing of $120 \mathrm{~kg}$ of plutonium from surplus nuclear weapons for the European Mixed Oxide (MOX) Lead Test Assembly (LTA). The document indicates that both oxalic acid and peroxide were used during the precipitation step and that the calcination temperature was $650{ }^{\circ} \mathrm{C}$ for 4 hours. Figure 5 in this reference shows specific surface area data points for many experiments but does not list any values. SRNL received a table of the values in Figure 5 from Laura Worl of LANL on 02/03/12 which is shown in Table 2-3. Note that all these SSA values are for calcination at $650{ }^{\circ} \mathrm{C}$ for 4 hours. This work is also described in greater detail in reference 16 of this literature review. All the specific surface area data in Table 2-3 was used in the calculations even the Sample $10 \mathrm{~S}\left(4.93 \mathrm{~m}^{2} / \mathrm{g}\right)$ and Sample $47\left(14.86 \mathrm{~m}^{2} / \mathrm{g}\right)$ since the mean of the other $650{ }^{\circ} \mathrm{C}$ data was $9.34 \mathrm{~m}^{2} / \mathrm{g}$ with a standard deviation of 1.51 giving $3 \sigma$ or $99.7 \%$ inclusion limits of 5 to $14 \mathrm{~m}^{2} / \mathrm{g}$. 
SRNL-TR-2011-00334

Revision 0

Table 2-3. SSA Data for Figure 5 in Reference 7

\begin{tabular}{|c|c||c|c|}
\hline Sample & $\mathbf{S S A}\left[\mathbf{m}^{2} / \mathbf{g}\right]$ & Sample & SSA $\left[\mathbf{m}^{2} / \mathbf{g}\right]$ \\
\hline Sample10S & 4.93 & Sample33 & 11.14 \\
\hline Sample11 & 10.18 & Sample34 & 8.35 \\
\hline Sample12 & 9.76 & Sample35 & 8.11 \\
\hline Sample13 & 10.54 & Sample35R & 9.82 \\
\hline Sample14 & 10.86 & Sample36 & 11.20 \\
\hline Sample15 & 7.89 & Sample37 & 6.85 \\
\hline Sample16 & 8.47 & Sample38 & 7.45 \\
\hline Sample17 & 9.29 & Sample39 & 7.70 \\
\hline Sample18 & 8.64 & Sample40 & 7.82 \\
\hline Sample19 & 9.08 & Sample41 & 8.11 \\
\hline Sample20 & 8.30 & Sample42 & 8.22 \\
\hline Sample21 & 10.31 & Sample43 & 7.87 \\
\hline Sample22 & 10.23 & Sample44 & 8.75 \\
\hline Sample23 & 8.91 & Sample45 & 9.01 \\
\hline Sample24 & 13.56 & Sample46 & 9.89 \\
\hline Sample25 & 11.50 & Sample47 & 14.86 \\
\hline Sample26 & 10.37 & Sample48 & 9.07 \\
\hline Sample27 & 8.04 & Sample49 & 7.77 \\
\hline Sample28 & 9.07 & Sample50 & 8.19 \\
\hline Sample29 & 8.90 & Sample52 & 9.07 \\
\hline Sample30 & 10.54 & Sample54 & 9.37 \\
\hline Sample31 & 12.04 & Sample53 & 9.26 \\
\hline Sample32 & 13.51 & & \\
\hline & & & \\
\hline
\end{tabular}

\subsubsection{Reference 8: Effect of Oxalate Precipitation on $\mathrm{PuO}_{2}$ Microstructures}

This reference ${ }^{8}$ describes how the conditions of plutonium oxalate precipitation can affect the microstructure properties of calcined $\mathrm{PuO}_{2}$. This document has specific surface area data in its Figure 2 and 3 from $\mathrm{Pu}(\mathrm{III})$ and $\mathrm{Pu}(\mathrm{IV})$ oxalate from direct and reverse strike of $0.9 \mathrm{M}$ oxalic acid to $0.7-1.1 \mathrm{M} \mathrm{HNO}_{3}, 5 \mathrm{~g} / \mathrm{L} \mathrm{Pu}$ solutions at $22{ }^{\circ} \mathrm{C}$ to $55^{\circ} \mathrm{C}$ during the precipitation step. Figure 2 in this reference contained calcination temperature and time, specific surface area, and crystal size data. Figure 3 in this reference only contained calcination temperature but no time for the specific surface area data. It is believed the specific surface area data shown in Figure 3 of this reference comes from reference 58 and possibly other references in this review and therefore will not be used in the later empirical fits. The specific surface area data in Figure 2 of this reference will be used in the correlations except for the $735^{\circ} \mathrm{C}, 14 \mathrm{~m}^{2} / \mathrm{g}$ data point since the mean of the other $735^{\circ} \mathrm{C}$ values was $6.17 \mathrm{~m}^{2} / \mathrm{g}$ with a standard deviation of 1.93 giving $3 \sigma$ or $99.7 \%$ inclusion limits of 0.4 to $12 \mathrm{~m}^{2} / \mathrm{g}$. 
SRNL-TR-2011-00334

Revision 0

\subsubsection{Reference 9: A critical examination of the thermodynamics of water adsorption on actinide} oxide surfaces

This reference ${ }^{9}$ discusses the thermodynamics of water adsorption/desorption with respect to $\mathrm{PuO}_{2}$ and presents a kinetic model for the water adsorption/desorption. The article does indicate that high calcination temperatures lead to lower specific surface area, which in turn leads to less water adsorption. However, no specific surface area data was given in this document that could be used in the modeling.

\subsubsection{Reference 10: Development of Plutonium Bearing Fuel Materials NUMEC P-100}

This reference ${ }^{10}$ documents early work for the preparation and characterization of $\mathrm{PuO}_{2}$ and $\mathrm{PuO}_{2}-\mathrm{UO}_{2}$ materials. Table 2.4 lists some specific surface area data but it is for co-precipitated $\mathrm{UO}_{2}-5 \mathrm{wt} \% \mathrm{PuO}_{2}$ and the document indicates that several calcination steps were used without measuring the intermediate surface area values. No specific surface area data was given in this document that could be used in the calculations.

\subsubsection{Reference 11: Nanoceria - Energetics of Surfaces, Interfaces and Water Adsorption}

This reference ${ }^{11}$ looks at deriving the relation for surface enthalpy of $\mathrm{CeO}_{2}$. There is no specific surface area data for $\mathrm{PuO}_{2}$. The article does have in its Table 1 specific surface area data for $\mathrm{CeO}_{2}$ which will be noted for comparison with $\mathrm{PuO}_{2}$. No specific surface area data for $\mathrm{PuO}_{2}$ was given in this document that could be used for model development.

\subsubsection{Reference 12: Technical Basis for Packaging Glovebox Moisture Content}

This reference ${ }^{12}$ describes the thermodynamics of water adsorption onto calcined $\mathrm{PuO}_{2}$. There is no specific surface area data for $\mathrm{PuO}_{2}$ in this document but the article suggests keeping relative humidity low and putting freshly made $\mathrm{PuO}_{2}$ into seal;ed containers to limit water adsorption. No specific surface area data for $\mathrm{PuO}_{2}$ was given in this article that could be used for predictions.

\subsubsection{Reference 13: Gas Generation from Water Adsorbed onto Pure Plutonium Dioxide Powder}

This reference ${ }^{13}$ discusses the generation of $\mathrm{H}_{2}$ from $\alpha$-particle radiolysis of water adsorbed onto plutonium dioxide. The article points out that the specific surface area strongly affects the amount of water adsorbed. The article states that if freshly calcined $\mathrm{PuO}_{2}$ material is put in a hermetically sealed container right after calcination then moisture in the air will be adsorbed as hydroxyl on the surface of the $\mathrm{PuO}_{2}$ preventing the radiolysis of water in the container to $\mathrm{H}_{2}$. Table 1 in the article gives specific surface areas for $600^{\circ} \mathrm{C}$ and $975^{\circ} \mathrm{C}$. The article does not reveal the calcination times but SRNL received an email on 02/03/12 from Laura Worl of LANL that stated that the $600{ }^{\circ} \mathrm{C}$ calcination was at 6 hours and the $975{ }^{\circ} \mathrm{C}$ calcination was at 4 hours 
(following an initial 6 hours at $600{ }^{\circ} \mathrm{C}$ ). The logic chosen for the calcination time $\mathrm{t}_{2}$ for the temperature $975^{\circ} \mathrm{C}$ is calculated as follows:

$$
t_{2}=\frac{600}{975} \cdot 6+4
$$

Therefore the calcination time for the $975{ }^{\circ} \mathrm{C}$ data point will be treated as 7.69 hours. This calcination data will be used in the calculations.

\subsubsection{Reference 14: Gas Generation Testing of Plutonium Dioxide}

This reference ${ }^{14}$ discusses hydrogen and oxygen gas generation rates for plutonium oxide as a function of several parameters including water content and specific surface area. There is no specific surface area data for $\mathrm{PuO}_{2}$ in this document but reference 17 of this report does contain the specific surface area data associated with these samples. This reference quantifies $\mathrm{H}_{2}$ and $\mathrm{O}_{2}$ generation based on water content for $\mathrm{PuO}_{2}$ calcined at different temperatures. No specific surface area data for $\mathrm{PuO}_{2}$ was taken from this article for the calculations.

\subsubsection{Reference 15: Effect of Precipitation Conditions on the Specific Surface Area of Neptunium Oxide}

This reference ${ }^{15}$ discusses the precipitation of neptunium oxalate and its calcination to form $\mathrm{NpO}_{2}$ under normal and bounding HB-Line flowsheet conditions. The report concludes that the calcination time has a bigger effect on the specific surface area of the $\mathrm{NpO}_{2}$ than the molarity of the nitric acid solution used for the precipitation. There was no $\mathrm{PuO}_{2}$ specific surface area data in this article that could be used in the regression.

\subsubsection{Reference 16: Plutonium Oxide Polishing for MOX Fuel Production}

This reference ${ }^{16}$ contains data from LANL on the polishing of $120 \mathrm{~kg}$ of plutonium from surplus nuclear weapons for the European Mixed Oxide (MOX) Lead Test Assembly (LTA). The plutonium is precipitated as plutonium oxalate by adding oxalic acid to a $2.5 \mathrm{M} \mathrm{HNO}_{3} \mathrm{Pu}$ solution at $65^{\circ} \mathrm{C}$. The plutonium oxalate precipitate was then filtered and washed with dilute oxalic acid in $2 \mathrm{M} \mathrm{HNO}_{3}$. The reference indicates that some $\mathrm{PuO}_{2}$ samples were held at $200{ }^{\circ} \mathrm{C}$ for 6 hours then ramped to the calcination temperature at $150{ }^{\circ} \mathrm{C}$ per hour. The document lists only an average specific surface area value of $9.77 \mathrm{~m}^{2} / \mathrm{g}$ for calcining $\mathrm{PuO}_{2}$ at $650{ }^{\circ} \mathrm{C}$ for 4 hours. The detailed data for this reference is actually contained in Reference 7 which has already been included in the model development. 
SRNL-TR-2011-00334

Revision 0

\subsubsection{Reference 17: Surface Area (BET) and TGA-MS Analysis of Calcined Neptunium Oxide}

This reference ${ }^{17}$ discusses gas generation tests and moisture measurements for $\mathrm{NpO}_{2}$ for the 9975 Safety Analysis Report for Packaging (SARP). This article describes the experimental and analytical testing equipment used to produce $\mathrm{NpO}_{2}$ following the January 2003 version of the HB-Line Phase II flowsheet. Although this report focuses on the $\mathrm{NpO}_{2}$, there are some $\mathrm{PuO}_{2}$ specific surface area data in Table 1 and 9 of this reference. Note that these $\mathrm{PuO}_{2}$ samples are also discussed in reference 6 and 14 of this literature review concerning gas generation for long term storage. This reference indicates that all the $\mathrm{PuO}_{2}$ samples were held at $450{ }^{\circ} \mathrm{C}$ for 4 hours then heated to their final calcination temperature for 2 hours. For this reason, the calcination times $t_{2}$ for calcination temperature $\mathrm{T}_{2}$ are calculated as follows:

$$
t_{2}=\frac{450}{T_{2}} \cdot 4+2
$$

For example, the calcination time for the $950{ }^{\circ} \mathrm{C}$ data is treated as 3.89 hours. All the $\mathrm{PuO}_{2}$ specific surface area data points from this reference were used in the regression.

\subsubsection{Reference 18: Moisture and Surface Area Measurements of Plutonium-Bearing Oxides}

This reference ${ }^{18}$ discusses the moisture and surface area measurements of plutonium oxide samples prepared at $950^{\circ} \mathrm{C}$ for 2 hours. This report has some specific surface area data in its Table 2 but the surface area points were lower than other values seen in this literature review. The article notes that the SSA values are lower than normal and indicates that the presence of chloride salts may be the reason. For this reason and since other data was available at this temperature, no $\mathrm{PuO}_{2}$ specific surface area data in this article was used for the later empirical fits.

\subsubsection{Reference 19: Hydration of Plutonium Oxide and Process Salts $\mathrm{NaCl}, \mathrm{KCl}, \mathrm{CaCl}, \mathrm{MgCl}_{2}$}

This reference ${ }^{19}$ is a literature review of the data for dehydration and rehydration of $\mathrm{PuO}_{2}, \mathrm{NaCl}$, $\mathrm{KCl}, \mathrm{CaCl}_{2}$, and $\mathrm{MgCl}_{2}$ and impure oxides containing chloride salts. The pure $\mathrm{PuO}_{2}$ specific surface area data in this article is the same data already cited in Reference 2 and 3 of this literature review. Therefore there is no new $\mathrm{PuO}_{2}$ specific surface area data in this article to develop correlations.

\subsubsection{Reference 20: Thermodynamics of Water Sorption on $\mathrm{PuO}_{2}$ : Consequences for Oxide Storage and Solubility}

This reference ${ }^{20}$ discusses the thermodynamics of water adsorption/desorption with respect to $\mathrm{PuO}_{2}$ and derives the Gibbs free energies associated with the adsorption/desorption. The article does not contain any specific surface area for $\mathrm{PuO}_{2}$ that could be used for our purpose. 
SRNL-TR-2011-00334

Revision 0

\subsubsection{Reference 21: Surface chemistry of Pu oxides}

This reference ${ }^{21}$ examines the surface chemistry of $\mathrm{Pu}(\mathrm{IV})$ compounds including $\mathrm{PuO}_{2}$ and $\mathrm{Pu}(\mathrm{OH})_{4}$. The different $\mathrm{Pu}$ oxidation states are discussed and the impact of temperature on them. The article did indicate that the $\mathrm{PuO}_{2}$ surfaces formed hydroxyls when exposed to moisture in the air which persisted to $590{ }^{\circ} \mathrm{C}$. However, the article does not contain any specific surface area for $\mathrm{PuO}_{2}$ that could be used for calculations.

\subsubsection{Reference 22: Thermodynamic Data for Hydrous and Anhydrous $\mathrm{PuO}_{2+x}(\mathrm{~s})$}

This reference ${ }^{22}$ discusses the thermodynamic properties of hydrous and anhydrous $\mathrm{PuO}_{2+\mathrm{x}}$ compounds. However, the article does not contain any specific surface area for $\mathrm{PuO}_{2}$ that could be regressed.

\subsubsection{Reference 23: Calculations of Thermodynamic Properties of $\mathrm{PuO}_{2}$ by the First-Principles and Lattice Vibration}

This reference ${ }^{23}$ describes the thermodynamic properties of $\mathrm{PuO}_{2}$ using first-principles and lattice dynamics calculations. This article does not contain any specific surface area for $\mathrm{PuO}_{2}$ that could be used to develop a model.

\subsubsection{Reference 24: Thermodynamic Modeling of the Plutonium-Oxygen System}

This reference ${ }^{24}$ examines the thermodynamic functions and phase equilibria of the plutoniumoxygen system. The article points out some inconsistencies found for the oxygen chemical potential and vaporization data of $\mathrm{Pu}_{2} \mathrm{O}_{3}+\mathrm{PuO}_{2-\mathrm{x}}$ and $\mathrm{PuO}_{2-\mathrm{x}}$ compounds. However, this article does not contain any specific surface area data or $\mathrm{PuO}_{2}$ for calculations.

\subsubsection{Reference 25: White Paper on Possible Inclusion of Mixed Plutonium-Uranium Oxides in} DOE-STD-3013-96

This reference ${ }^{25}$ describes properties for mixed $\mathrm{UO}_{2}-\mathrm{PuO}_{2}$ oxide $(5-35 \mathrm{wt} \% \mathrm{Pu}$ ) that are calcined under a $6 \mathrm{vol} \% \mathrm{H}_{2}$ and $94 \mathrm{vol} \% \mathrm{~N}_{2}$ environment. For this reason the specific surface area data in this article was not used in the later empirical correlations. The article does show that as the $\mathrm{Pu}$ wt \% increases in the co-precipitated samples that the specific surface area goes down.

2.2.26 Reference 26: Characterization of Representative Materials in Support of Safe, Long Term Storage of Surplus Plutonium in DOE-STD-3013 Containers

This reference ${ }^{26}$ has some specific surface area data versus different $\mathrm{PuO}_{2}$ preparation methods at $950{ }^{\circ} \mathrm{C}$ in its Figure 5 but gives no details like time or numerical values. For this reason the specific surface area data in this document was not included for calculations. 
SRNL-TR-2011-00334

Revision 0

\subsubsection{Reference 27: Characterization of Representative Materials in Support of Safe, Long Term} Storage of Surplus Plutonium in DOE-STD-3013 Containers

This reference ${ }^{27}$ discusses the process (block flow diagrams, equipment flowsheets, stream material balances) for plutonium(IV) oxalate precipitation and $\mathrm{PuO}_{2}$ calcination for a $100-\mathrm{kg}$ plutonium per day facility. The specific surface area data for $\mathrm{PuO}_{2}$ in Table 3 of this reference originates from reference 8 of the current report. There was no new specific surface area data in this document to be used in the calculations.

\subsubsection{Reference 28: Monthly Report Hanford Atomic Products Operation}

This reference ${ }^{28}$ provides a monthly status for the operations of the Hanford Purex Plant from 1956. The report only mentions that hydrated $\mathrm{UO}_{2}$ after 1 hour at $480^{\circ} \mathrm{C}$ had a specific surface area of $7.38 \mathrm{~m}^{2} / \mathrm{g}$. There was no specific surface area data for $\mathrm{PuO}_{2}$ in this document to be used in the model development.

\subsubsection{Reference 29: Savannah River Laboratory Monthly Report, ${ }^{238} \mathrm{Pu}$ Fuel Form Processes}

This reference ${ }^{29}$ provides a monthly status for the ${ }^{238} \mathrm{Pu}$ Fuel program at Savannah River Laboratory in 1973. Table 1 in this report lists some specific surface area measurements for ${ }^{238} \mathrm{PuO}_{2}$ calcined at $700{ }^{\circ} \mathrm{C}$. However, there were no calcination times given and the SSA values of $0.73,1.10$, and $1.73 \mathrm{~m}^{2} / \mathrm{g}$ were significantly lower than the other $700{ }^{\circ} \mathrm{C}$ data in this literature review $\left(5.7-10.8 \mathrm{~m}^{2} / \mathrm{g}\right)$. Therefore no specific surface area data for $\mathrm{PuO}_{2}$ in this document was used in the current modeling.

\subsubsection{Reference 30: Properties of Plutonium Dioxide}

This reference ${ }^{30}$ discusses the physical and chemical properties of $\mathrm{PuO}_{2}$ made from different starting materials like $\mathrm{Pu}\left(\mathrm{NO}_{3}\right)_{4}, \mathrm{Pu}(\mathrm{OH})_{4}$, and $\mathrm{Pu}\left(\mathrm{C}_{2} \mathrm{O}_{4}\right)_{2}$. All the starting materials in this document were dried at 120 to $140{ }^{\circ} \mathrm{C}$ for 1 hour then heated to the specified calcination temperature at a controlled rate in the muffle furnace that had a stirred bed. The report states that the stirring bed during calcination only seemed to make a difference in the uniformity of the oxides for the less than $400{ }^{\circ} \mathrm{C}$ calcination samples. This reference also states that plutonium oxalate does not completely decompose into $\mathrm{PuO}_{2}$ until reaching temperature greater than $300{ }^{\circ} \mathrm{C}$ and the $\mathrm{PuO}_{2}$ will not approach stoichiometry until the temperature goes above $800{ }^{\circ} \mathrm{C}$. Table 9 of this reference gives a specific surface area for $\mathrm{PuO}_{2}$ from oxalate of $41.4 \mathrm{~m}^{2} / \mathrm{g}$ at $400{ }^{\circ} \mathrm{C}$ but did not list the calcination time. Based on the other data in this literature review, it is assumed that the calcination time for this $400{ }^{\circ} \mathrm{C}$ point is 2.1 hours for the calculations. If other information becomes available then this calcination time can be changed. This reference also presents data on the solubility of $\mathrm{PuO}_{2}$ in various solvents like 12-16 M HNO3 with 0.002-0.01 $\mathrm{M} \mathrm{HF}$ and makes the generalization that the higher the calcination temperature the less soluble the oxide. Table 10 of this reference lists crystal size of $\mathrm{PuO}_{2}$ from the various starting materials over the various calcination temperatures. This reference also gives the moisture or water gain data for the $60,20,10 \mathrm{~m}^{2} / \mathrm{g} \mathrm{PuO}_{2}$ from oxalate and indicates that $\mathrm{Pu}$ oxalate decomposes to the oxide between 160 and $350{ }^{\circ} \mathrm{C}$. 
SRNL-TR-2011-00334

Revision 0

\subsubsection{Reference 31: Plutonium(III) Oxalate Precipitation and Calcination Process for} Plutonium Nitrate To Oxide Conversion

This reference ${ }^{31}$ discusses the equipment flowsheets and mass balances for plutonium(III) oxalate precipitation and $\mathrm{PuO}_{2}$ calcination for a $100-\mathrm{kg}$ plutonium per day facility. This report focuses on the precipitation and calcination process and the performance of the $\mathrm{PuO}_{2}$ manufactured. Three specific surface area data points at $600{ }^{\circ} \mathrm{C}, 750{ }^{\circ} \mathrm{C}$, and $735^{\circ} \mathrm{C}$ calcination temperatures are cited in Table 6 of this reference. The $600{ }^{\circ} \mathrm{C}$ data point came from adding 0.8 $\mathrm{M}$ oxalic acid at room temperature to a $1.3 \mathrm{M} \mathrm{HNO}_{3}, 32 \mathrm{~g} / \mathrm{L} \mathrm{Pu}$ solution (added sulfamic acid to stabilize valence) followed by filtering then washing with a $0.5 \mathrm{M} \mathrm{HNO}_{3}, 0.3 \mathrm{M} \mathrm{H}_{2} \mathrm{C}_{2} \mathrm{O}_{4}$ solution. The plutonium oxalate precipitate for this first data point was air dried at $110{ }^{\circ} \mathrm{C}$ for 3 hours, heated 1 hour in $\mathrm{N}_{2}$ at $150{ }^{\circ} \mathrm{C}$, heated to $600{ }^{\circ} \mathrm{C}$ in 1 hour in air, and then held at $600{ }^{\circ} \mathrm{C}$ for 3 hours in air. The $750{ }^{\circ} \mathrm{C}$ data point came from adding solid oxalic acid at room temperature to $1.84 \mathrm{M} \mathrm{HNO}_{3}, 125 \mathrm{~g} / \mathrm{L} \mathrm{Pu}$ solution (added urea to stabilize valence) followed by filtering then washing with water. The plutonium oxalate precipitate for this $750{ }^{\circ} \mathrm{C}$ data point was air dried at room temperature for 30 minutes, heated to $750{ }^{\circ} \mathrm{C}$ in 2 hours in steam, and then held at $750{ }^{\circ} \mathrm{C}$ for 4 hours in steam. The $735^{\circ} \mathrm{C}$ data point came from adding $0.9 \mathrm{M}$ oxalic acid at $35^{\circ} \mathrm{C}$ to a 1.5 $\mathrm{M} \mathrm{HNO}_{3}, 4-6 \mathrm{~g} / \mathrm{L} \mathrm{Pu}$ solution (added hydrazine to stabilize valence) followed by filtering then washing with a $0.5 \mathrm{M} \mathrm{HNO}_{3}, 0.2 \mathrm{M} \mathrm{H}_{2} \mathrm{C}_{2} \mathrm{O}_{4}$ solution. The plutonium oxalate precipitate for this third data point was heated immediately (no time given) to $735{ }^{\circ} \mathrm{C}$ in air then held at $735{ }^{\circ} \mathrm{C}$ for 2 hours in air. The $600{ }^{\circ} \mathrm{C}$ and $735^{\circ} \mathrm{C}$ specific surface area data points were used in the empirical fits discussed later since the calcination was in air and the $750{ }^{\circ} \mathrm{C}$ data point was not used since it was calcined in steam.

\subsubsection{Reference 32: Interim Report on Plutonium Oxalate Precipitation Work}

This reference ${ }^{32}$ examines how precipitation conditions like oxalate to plutonium molar ratio, ionic strength, residence time, temperature, and agitation affect plutonium oxalate properties like particle growth rates and particle structures. There was no specific surface area data for $\mathrm{PuO}_{2}$ in this document to be used in the modeling.

\subsubsection{Reference 33: Control of Particle Size and Structure}

This reference ${ }^{33}$ presents information on how the precipitation conditions of plutonium oxalate affect the particle size and structural properties of $\mathrm{PuO}_{2}$. There was no specific surface area data for $\mathrm{PuO}_{2}$ in this document to be used in the calculations.

\subsubsection{Reference 34: The Thermal Decomposition of Hydrated Plutonium(IV) Oxalates}

This reference ${ }^{34}$ presents thermal decomposition data for hydrated plutonium(IV) oxalates in air and in nitrogen over the temperature range of 20 to $830^{\circ} \mathrm{C}$. This reference states that in air the plutonium oxalate begins to lose waters of hydration at 45 to $60{ }^{\circ} \mathrm{C}$ and between 200 and $290{ }^{\circ} \mathrm{C}$ a mixture of $\mathrm{PuO}_{2}$ and $\mathrm{Pu}\left(\mathrm{CO}_{3}\right)_{2}$ forms. There was no specific surface area data for $\mathrm{PuO}_{2}$ in this reference to be used in the model development. 
SRNL-TR-2011-00334

Revision 0

\subsubsection{Reference 35: Precipitation of Plutonium(III) Oxalate and Calcination to Plutonium Dioxide}

This reference ${ }^{35}$ discusses the precipitation of plutonium(III) oxalate from nitric acid, hydrochloric acid, and sulfamic acid solutions then its calcination. This reference indicates that $\mathrm{Pu}(\mathrm{III})$ oxalate decomposes between 300 and $400{ }^{\circ} \mathrm{C}$. The calcination method used in this report was to heat in air from 25 to $125^{\circ} \mathrm{C}$ in 1 hour then hold at 1 hour then increase the temperature 3 to $5{ }^{\circ} \mathrm{C}$ per minute to the final calcination temperature. The sample would be held for 1 to 2 hours at the final calcination temperature and then allowed to cool to room temperature in an air stream. There was no specific surface area data for $\mathrm{PuO}_{2}$ in this reference.

\subsubsection{Reference 36: Thermal Decomposition of Plutonium (IV) Oxalate and Hydrofluorination of Plutonium (IV) Oxalate and Oxide}

This reference ${ }^{36}$ discusses the decomposition of plutonium(IV) oxalate and the factors affecting the reactivity of the plutonium oxide with hydrogen fluoride. Table 1 in this reference contains $\mathrm{PuO}_{2}$ particle sizes and surface area per unit volume data for various calcination temperatures but no calcination times. The $\mathrm{PuO}_{2}$ particle sizes of this reference do not seem to match the newer data (later than 1956) in this literature survey so it is recommended not to use it. Figure 18 of this reference has surface area per unit volume plotted versus calcination temperature but not in the same units as the other area data so it should not be used. No specific surface area data for $\mathrm{PuO}_{2}$ in this reference was used in the calculations.

\subsubsection{Reference 37: Thermal Decomposition of Plutonium Oxalates}

This reference ${ }^{37}$ discusses the various thermal decomposition forms for plutonium oxalate in air for $\mathrm{Pu}(\mathrm{III})$ and $\mathrm{Pu}(\mathrm{IV})$. There was no specific surface area data for $\mathrm{PuO}_{2}$ in this reference.

\subsubsection{Reference 38: Determination of Plutonium Dioxide Surface Areas from X-Ray Crystallite} Sizes

This reference ${ }^{38}$ describes a relationship between plutonium dioxide surface areas and the X-ray crystallite sizes. This article states that the X-ray average crystal size increases as the surface area decreases across the different starting materials like peroxide, metal, oxalate, hydroxide, etc. Note that the $\mathrm{PuO}_{2}$ in this article came from calcining plutonium peroxide. There was no specific surface area data for $\mathrm{PuO}_{2}$ in this reference.

\subsubsection{Reference 39: Development of Plutonium-Bearing Fuel Materials, NUMEC-2389-2}

This reference ${ }^{39}$ discusses early work for the preparation and characterization of $\mathrm{PuO}_{2}$ and $\mathrm{PuO}_{2}$ $\mathrm{UO}_{2}$ materials. For this reference $0.8 \mathrm{M}$ peroxide was added to $3 \mathrm{M} \mathrm{HNO}$, 26.4-69.6 g/L Pu solutions followed by $1 \mathrm{M}$ oxalic acid with holdup of 30 minutes to form the plutonium oxalate and the precipitate was dried at $100{ }^{\circ} \mathrm{C}$ or $180^{\circ} \mathrm{C}$ for 16 hours before the calcination. Table 2 of this reference contains $\mathrm{PuO}_{2}$ specific surface area data for $760{ }^{\circ} \mathrm{C}$ calcination with relative short calcination times (0.3-0.5 hours). Since this surface area data matched other data in this literature review, all the data points were used in the regression. 
SRNL-TR-2011-00334

Revision 0

\subsubsection{Reference 40: Development of Plutonium Bearing Fuel Materials, NUMEC-2389-3}

This reference ${ }^{40}$ documents early work for the preparation and characterization of $\mathrm{PuO}_{2}$ and $\mathrm{PuO}_{2}-\mathrm{UO}_{2}$ materials concerning the extrusion of plutonium wire. No specific surface area data was given.

\subsubsection{Reference 41: Development of Plutonium Bearing Fuel Materials, NUMEC-2389-4}

This reference ${ }^{41}$ documents early work for the preparation and characterization of $\mathrm{PuO}_{2}$ and $\mathrm{PuO}_{2}-\mathrm{UO}_{2}$ materials concerning mixed oxide sintering studies, preparation of high burn up test specimens, and physical property measurements. This reference focuses on co-precipitated $\mathrm{UO}_{2}-$ $\mathrm{PuO}_{2}$ materials but there is some $\mathrm{PuO}_{2}$ specific surface area in Tables 2.3 and 2.4. However, this surface area data is a repeat of the data in Reference 39 of this literature review. Therefore, no new specific surface area data from this reference will be included in the calculations.

\subsubsection{Reference 42: Irradiation Testing of $\mathrm{UO}_{2}-\mathrm{PuO} \mathrm{O}_{2}$ Fuels, NUMEC-3432-6}

This reference ${ }^{42}$ documents early work for the preparation and characterization of $\mathrm{PuO}_{2}$ and $\mathrm{PuO}_{2}-\mathrm{UO}_{2}$ materials concerning the irradiation of instrumented capsules containing $\mathrm{UO}_{2}-\mathrm{PuO}_{2}$. No specific surface area data was given.

\subsubsection{Reference 43: Development of Plutonium Bearing Fuel Materials, NUMEC-P-20}

This reference ${ }^{43}$ documents early work for the preparation and characterization of $\mathrm{PuO}_{2}$ and $\mathrm{PuO}_{2}-\mathrm{UO}_{2}$ materials concerning glove-box and equipment setup. This reference had some specific surface area data for thoria. However, no $\mathrm{PuO}_{2}$ specific surface area data was provided.

\subsubsection{Reference 44: Development of Plutonium Bearing Fuel Materials, NUMEC-P-34}

This reference ${ }^{44}$ documents early work for the preparation and characterization of $\mathrm{PuO}_{2}$ and $\mathrm{PuO}_{2}-\mathrm{UO}_{2}$ materials. This reference had some specific surface area data for co-precipitated $\mathrm{UO}_{2}-$ $\mathrm{PuO}_{2}$ from ammonia. However, no $\mathrm{PuO}_{2}$ specific surface area data was included.

\subsubsection{Reference 45: Development of Plutonium Bearing Fuel Materials, NUMEC-P-37}

This reference ${ }^{45}$ documents early work for the preparation and characterization of $\mathrm{PuO}_{2}$ and $\mathrm{PuO}_{2}-\mathrm{UO}_{2}$ materials. This reference had some specific surface area data for co-precipitated $\mathrm{UO}_{2}-$ $\mathrm{PuO}_{2}$ from ammonia but no $\mathrm{PuO}_{2}$ specific surface area data.

\subsubsection{Reference 46: Development of Plutonium Bearing Fuel Materials, NUMEC-P-39}

This reference ${ }^{46}$ documents early work for the preparation and characterization of $\mathrm{PuO}_{2}$ and $\mathrm{PuO}_{2}-\mathrm{UO}_{2}$ materials. No $\mathrm{PuO}_{2}$ specific surface area data was identified. 
SRNL-TR-2011-00334

Revision 0

\subsubsection{Reference 47: Development of Plutonium Bearing Fuel Materials, NUMEC-P-40}

This reference ${ }^{47}$ documents early work for the preparation and characterization of $\mathrm{PuO}_{2}$ and $\mathrm{PuO}_{2}-\mathrm{UO}_{2}$ materials. This reference had some specific surface area data for $\mathrm{UO}_{2}$ from ammonia but none for $\mathrm{PuO}_{2}$.

\subsubsection{Reference 48: Development of Plutonium Bearing Fuel Materials, NUMEC-P-44}

This reference ${ }^{48}$ documents early work for the preparation and characterization of $\mathrm{PuO}_{2}$ and $\mathrm{PuO}_{2}-\mathrm{UO}_{2}$ materials concerning the preparation and characterization of samples for in-pile tests. $\mathrm{No} \mathrm{PuO}_{2}$ specific surface area data was included.

\subsubsection{Reference 49: Development of Plutonium-Bearing Fuel Materials, NUMEC-P-60}

This reference ${ }^{49}$ discusses early work for the preparation and characterization of $\mathrm{PuO}_{2}$ and $\mathrm{PuO}_{2}$ $\mathrm{UO}_{2}$ materials. For this reference $0.8 \mathrm{M}$ peroxide was added to a $3 \mathrm{M} \mathrm{HNO}_{3}, 100 \mathrm{~g} / \mathrm{L} \mathrm{Pu}$ solution followed by $1 \mathrm{M}$ oxalic acid at $55{ }^{\circ} \mathrm{C}$ with holdup of 65 minutes to form the plutonium oxalate which was then filtered. The filtered precipitate was then dried 5 hours in air at $80{ }^{\circ} \mathrm{C}, 5$ hours at $130{ }^{\circ} \mathrm{C}$, and then 1 hour at $180{ }^{\circ} \mathrm{C}$ before the calcination. Table 2.1 of this reference gives a specific surface area of $28.7 \mathrm{~m}^{2} / \mathrm{g}$ for the $350{ }^{\circ} \mathrm{C}$ calcination. Even though this $350^{\circ}$ data point seems low, the mean of the other $350{ }^{\circ} \mathrm{C}$ data was $59.46 \mathrm{~m}^{2} / \mathrm{g}$ with a standard deviation of 13.31 giving $3 \sigma$ or $99.7 \%$ inclusion limits of 20 to $99 \mathrm{~m}^{2} / \mathrm{g}$ so this data point will be used in the calculations.

\subsubsection{Reference 50: Development of Plutonium-Bearing Fuel Materials, NUMEC-P-70}

This reference ${ }^{50}$ discusses early work for the preparation and characterization of $\mathrm{PuO}_{2}$ and $\mathrm{PuO}_{2}$ $\mathrm{UO}_{2}$ materials. For this reference $0.25 \mathrm{M}$ peroxide was added to a $3 \mathrm{M} \mathrm{HNO}_{3}, 100 \mathrm{~g} / \mathrm{L} \mathrm{Pu}$ solution followed by $1 \mathrm{M}$ oxalic acid at $28{ }^{\circ} \mathrm{C}$ with holdup of 20 minutes to form the plutonium oxalate which was then filtered. This reference states that the plutonium oxalate was washed with an unspecified amount of deionized water then air dried for 10 minutes then placed in a forced-convection oven for an unspecified time and temperature to remove excess moisture before calcination. Table 2.1 and 2.2 of this reference give $\mathrm{PuO}_{2}$ specific surface area data but there are no calcination times listed. Therefore, no $\mathrm{PuO}_{2}$ specific surface area data in this document will be used in the calculations.

\subsubsection{Reference 51: Development of Plutonium Bearing Fuel Materials, NUMEC-P-101}

This reference ${ }^{51}$ documents early work for the preparation and characterization of $\mathrm{PuO}_{2}$ and $\mathrm{PuO}_{2}-\mathrm{UO}_{2}$ materials. In Table 2.4 of this reference are specific surface area data for $\mathrm{UO}_{2}$. No $\mathrm{PuO}_{2}$ specific surface area data was listed. 
SRNL-TR-2011-00334

Revision 0

\subsubsection{Reference 52: Development of Plutonium Bearing Fuel Materials, NUMEC-P-102}

This reference ${ }^{52}$ documents early work for the preparation and characterization of $\mathrm{PuO}_{2}$ and $\mathrm{PuO}_{2}-\mathrm{UO}_{2}$ materials. This reference has specific surface area data for co-precipitated $\mathrm{UO}_{2}$ with $0.5,12.5$, and $35 \mathrm{wt} \% \mathrm{PuO}_{2}$. Figure 2.2 in this reference shows that the higher weight percent $\mathrm{PuO}_{2}$ in the co-precipitated oxide and a reducing $\mathrm{N}_{2}$ calcination environment lowers the specific surface area of the oxides. Table 2.6 in this reference has specific surface area data for $\mathrm{PuO}_{2}$ from hydroxide. However, no pure $\mathrm{PuO}_{2}$ from oxalate specific surface area data was given.

\subsubsection{Reference 53: Development of Plutonium-Bearing Fuel Materials, NUMEC-P-103}

This reference ${ }^{53}$ discusses early work for the preparation and characterization of $\mathrm{PuO}_{2}$ and $\mathrm{PuO}_{2}$ $\mathrm{UO}_{2}$ materials. For this reference $0.8 \mathrm{M}$ peroxide was added to $3 \mathrm{M} \mathrm{HNO}_{3}, 100-200 \mathrm{~g} / \mathrm{L} \mathrm{Pu}$ solutions followed by $1 \mathrm{M}$ oxalic acid at $35^{\circ} \mathrm{C}$ with holdup of 30 minutes to form the plutonium oxalate. The plutonium oxalate was then dried at $180{ }^{\circ} \mathrm{C}$ for 16 hours. This reference states that the plutonium oxalate was washed with 1 liter of deionized water before calcining at $760{ }^{\circ} \mathrm{C}$ for 30 minutes. Table 2.3 of this reference gives $\mathrm{PuO}_{2}$ specific surface area data which was used in the current calculations.

\subsubsection{Reference 54: Development of Plutonium-Bearing Fuel Materials, NUMEC-P-104}

This reference ${ }^{54}$ discusses early work for the preparation and characterization of $\mathrm{PuO}_{2}$ and $\mathrm{PuO}_{2}$ $\mathrm{UO}_{2}$ materials concerning the formation of $\mathrm{PuO}_{2}$ from peroxide. This reference states that the peroxide precipitation behaved like the oxalate precipitation. However, since the $\mathrm{PuO}_{2}$ was not formed by oxalate precipitation, the specific surface area data were not used.

\subsubsection{Reference 55: Development of Plutonium Bearing Fuel Materials, NUMEC-P-105}

This reference ${ }^{55}$ documents early work for the preparation and characterization of $\mathrm{PuO}_{2}$ and $\mathrm{PuO}_{2}-\mathrm{UO}_{2}$ materials. For this reference $0.8 \mathrm{M}$ peroxide was added to a $3 \mathrm{M} \mathrm{HNO}_{3}, 200 \mathrm{~g} / \mathrm{L} \mathrm{Pu}$ solution followed by $1 \mathrm{M}$ oxalic acid at $35^{\circ} \mathrm{C}$ with holdup of 30 minutes to form the plutonium oxalate. The plutonium oxalate precipitate was then dried at $100{ }^{\circ} \mathrm{C}$ for 24 hours before calcining at $760{ }^{\circ} \mathrm{C}$ for 30 minutes. Table 2.4 of this reference gives a specific surface area of $4.88 \mathrm{~m}^{2} / \mathrm{g}$ for this $\mathrm{PuO}_{2}$ sample. This reference has mostly specific surface area data for coprecipitated $\mathrm{UO}_{2}$ with $0.5,12.5,35$ and $\mathrm{wt} \% \mathrm{PuO}_{2}$. This data point was used in the calculations.

\subsubsection{Reference 56: Development of Plutonium-Bearing Fuel Materials, NUMEC-P-103}

This reference ${ }^{56}$ discusses early work for the preparation and characterization of $\mathrm{PuO}_{2}$ and $\mathrm{PuO}_{2}$ $\mathrm{UO}_{2}$ materials. For this reference $0.8 \mathrm{M}$ peroxide was added to a $3 \mathrm{M} \mathrm{HNO}_{3}, 228.3 \mathrm{~g} / \mathrm{L} \mathrm{Pu}$ solution followed by $1 \mathrm{M}$ oxalic acid at $35^{\circ} \mathrm{C}$ with holdup of 30 minutes to form the plutonium oxalate which was then dried for 16 hours at $150{ }^{\circ} \mathrm{C}$ before calcination. Table 2.2 of this reference gives $\mathrm{PuO}_{2}$ specific surface area data that was used in the calculations. 
SRNL-TR-2011-00334

Revision 0

\subsubsection{Reference 57: Ceramic Properties of $\mathrm{PuO}_{2}$}

This reference ${ }^{57}$ is a literature survey of the physical properties for $\mathrm{PuO}_{2}$ from NUMEC-P-10 through P-106, NUMEC-2389-1,4,6 reports as well as many other references. This reference contains specific surface area which originates from reference 4 (NUMEC-P-80) and 5 (NUMEC-P-90) of this literature review. Therefore, no new $\mathrm{PuO}_{2}$ specific surface area data is available from this document.

\subsubsection{Reference 58: Savannah River Laboratory Monthly Report: Pu-238 Fuel Form Process}

This reference ${ }^{58}$ contains some SSA data in its Table 5 for reverse and direct strike of $0.9 \mathrm{M}$ Oxalic acid to a $0.4 \mathrm{M} \mathrm{HNO3,4} \mathrm{g} / \mathrm{L} \mathrm{Pu}$ feed solution with hydrazine and ascorbic acid. This reference concludes that the SSA is independent of the particle morphology but dependent on the internal porosity of the $\mathrm{PuO}_{2}$. This reference also discusses how $\mathrm{Pu}_{2}\left(\mathrm{C}_{2} \mathrm{O}_{4}\right)_{3} * 10 \mathrm{H}_{2} \mathrm{O}$ dehydrates at 55 to $195{ }^{\circ} \mathrm{C}$ to form $\mathrm{Pu}_{2}\left(\mathrm{C}_{2} \mathrm{O}_{4}\right)_{3}$ and loses $\mathrm{CO}$ and $\mathrm{CO}_{2}$ at 300 to $350{ }^{\circ} \mathrm{C}$ to form $\mathrm{PuO}_{2}$. This reference also states that the 10 to $15 \mathrm{~m}^{2} / \mathrm{g}$ increase in surface area from $250{ }^{\circ} \mathrm{C}$ to $350{ }^{\circ} \mathrm{C}$ may be due to lattice disruption from gas evolution or a change in crystallite size between the oxide and the oxalate phases. The specific surface area data from this document will be used in the calculations.

\subsection{Calcination Temperature, Time, and Specific Surface Area Data from Literature Reviewed}

Table 2-4 lists all the calcination temperature, time, and specific surface area data from all the references cited in Section 2.2. An * next to a calcination time means that it is an estimated value based on other times from this data set or how the sample was calcined (see each reference in Section 2.2). Should more correct calcination times be identified then the values can be updated. The SSA values with superscripts are not used in the correlation. The superscripts are ${ }^{\mathrm{t}}$ missing time, ${ }^{\mathrm{p}}$ peroxide precipitation, ${ }^{\sigma}$ outside $\pm 3 \sigma$ limits, ${ }^{\mathrm{h}}$ mixed plutonium-uranium oxides calcined in $6 \mathrm{vol} \% \mathrm{H}_{2}-94 \mathrm{vol} \% \mathrm{~N}_{2}$, ${ }^{\text {a }}$ average value of Ref 7 values, ${ }^{\mathrm{d}}$ duplicate reference value, and ${ }^{\mathrm{s}}$ calcined in steam. More details of these exclusions are in Section 2.2 for each reference. These choices can be modified later as more information becomes available. Figure 2-1 is a plot of the calcination temperature versus the specific surface area data for all the references. 
Table 2-4. All Calcination Temperature, Time, and SSA Data

\begin{tabular}{|c|c|c|c|c|}
\hline $\begin{array}{c}\text { Calcination } \\
\text { Temperature }\left[{ }^{\circ} \mathrm{C}\right]\end{array}$ & $\begin{array}{c}\text { Calcination Time } \\
{[\mathrm{h}]}\end{array}$ & $\mathrm{SSA}\left[\mathrm{m}^{2} / \mathrm{g}\right]$ & Reference & Year \\
\hline 250 & 2.0 & 61 & 58 & 1975 \\
\hline 250 & 2.0 & 61.7 & 58 & 1975 \\
\hline 350 & 0.25 & 52 & 5 & 1961 \\
\hline 350 & 0.50 & 43 & 4 & 1961 \\
\hline 350 & NA & $25.8^{\mathrm{t}}$ & 50 & 1961 \\
\hline 350 & 1.0 & 28.7 & 49 & 1961 \\
\hline 350 & 2.0 & 68.9 & 58 & 1975 \\
\hline 350 & 2.0 & 76.4 & 58 & 1975 \\
\hline 350 & $2.1^{*}$ & 57 & 3 & 1995 \\
\hline 400 & $2.1 *$ & 41.4 & 30 & 1965 \\
\hline 450 & 4 & 38.88 & 17 & 2003 \\
\hline 450 & 4 & 39.09 & 17 & 2003 \\
\hline 450 & 4 & 40.56 & 17 & 2003 \\
\hline 450 & 4 & 40.97 & 17 & 2003 \\
\hline 450 & 10 & $12.3^{\sigma}$ & 1 & 1996 \\
\hline 490 & NA & $17.9^{t}$ & 50 & 1961 \\
\hline 490 & 0.5 & $19.5^{\mathrm{p}}$ & 54 & 1963 \\
\hline 490 & 0.5 & $23.7^{\mathrm{p}}$ & 54 & 1963 \\
\hline 490 & 0.5 & $26^{\mathrm{p}}$ & 54 & 1963 \\
\hline 550 & 2.0 & 30.6 & 58 & 1975 \\
\hline 550 & 2.0 & 41.1 & 58 & 1975 \\
\hline 550 & $9.09 *$ & $9.1^{\sigma}$ & 1 & 1996 \\
\hline 600 & 3 & 27 & 31 & 1980 \\
\hline 600 & 6 & 21 & 13 & 2006 \\
\hline 600 & 12 & 23.9 & 3 & 1995 \\
\hline 650 & 1.3 & $10^{\mathrm{h}}$ & 25 & 1997 \\
\hline 650 & 4 & $9.77^{\mathrm{a}}$ & 16 & 2005 \\
\hline 650 & 4 & 4.93 & 7 & 2007 \\
\hline 650 & 4 & 10.18 & 7 & 2007 \\
\hline 650 & 4 & 9.76 & 7 & 2007 \\
\hline 650 & 4 & 10.54 & 7 & 2007 \\
\hline 650 & 4 & 10.86 & 7 & 2007 \\
\hline 650 & 4 & 7.89 & 7 & 2007 \\
\hline 650 & 4 & 8.47 & 7 & 2007 \\
\hline 650 & 4 & 9.29 & 7 & 2007 \\
\hline 650 & 4 & 8.64 & 7 & 2007 \\
\hline 650 & 4 & 9.08 & 7 & 2007 \\
\hline 650 & 4 & 8.30 & 7 & 2007 \\
\hline 650 & 4 & 10.31 & 7 & 2007 \\
\hline 650 & 4 & 10.23 & 7 & 2007 \\
\hline 650 & 4 & 8.91 & 7 & 2007 \\
\hline 650 & 4 & 13.56 & 7 & 2007 \\
\hline 650 & 4 & 11.50 & 7 & 2007 \\
\hline
\end{tabular}


Table 2-4. All Calcination Temperature, Time, and SSA Data

\begin{tabular}{|c|c|c|c|c|}
\hline $\begin{array}{c}\text { Calcination } \\
\text { Temperature }\left[{ }^{\circ} \mathrm{C}\right]\end{array}$ & $\begin{array}{c}\text { Calcination Time } \\
{[\mathrm{h}]}\end{array}$ & $\mathrm{SSA}\left[\mathrm{m}^{2} / \mathrm{g}\right]$ & Reference & Year \\
\hline 650 & 4 & 10.37 & 7 & 2007 \\
\hline 650 & 4 & 8.04 & 7 & 2007 \\
\hline 650 & 4 & 9.07 & 7 & 2007 \\
\hline 650 & 4 & 8.90 & 7 & 2007 \\
\hline 650 & 4 & 10.54 & 7 & 2007 \\
\hline 650 & 4 & 12.04 & 7 & 2007 \\
\hline 650 & 4 & 13.51 & 7 & 2007 \\
\hline 650 & 4 & 11.14 & 7 & 2007 \\
\hline 650 & 4 & 8.35 & 7 & 2007 \\
\hline 650 & 4 & 8.11 & 7 & 2007 \\
\hline 650 & 4 & 9.82 & 7 & 2007 \\
\hline 650 & 4 & 11.20 & 7 & 2007 \\
\hline 650 & 4 & 6.85 & 7 & 2007 \\
\hline 650 & 4 & 7.45 & 7 & 2007 \\
\hline 650 & 4 & 7.70 & 7 & 2007 \\
\hline 650 & 4 & 7.82 & 7 & 2007 \\
\hline 650 & 4 & 8.11 & 7 & 2007 \\
\hline 650 & 4 & 8.22 & 7 & 2007 \\
\hline 650 & 4 & 7.87 & 7 & 2007 \\
\hline 650 & 4 & 8.75 & 7 & 2007 \\
\hline 650 & 4 & 9.01 & 7 & 2007 \\
\hline 650 & 4 & 9.89 & 7 & 2007 \\
\hline 650 & 4 & 14.86 & 7 & 2007 \\
\hline 650 & 4 & 9.07 & 7 & 2007 \\
\hline 650 & 4 & 7.77 & 7 & 2007 \\
\hline 650 & 4 & 8.19 & 7 & 2007 \\
\hline 650 & 4 & 9.07 & 7 & 2007 \\
\hline 650 & 4 & 9.37 & 7 & 2007 \\
\hline 650 & 4 & 9.26 & 7 & 2007 \\
\hline 650 & $8.46^{*}$ & 7.9 & 1 & 1996 \\
\hline 700 & NA & $1.73^{t}$ & 29 & 1973 \\
\hline 700 & 12 & $5.7^{\mathrm{d}}$ & 2 & 1997 \\
\hline 700 & 12 & 5.7 & 3 & 1995 \\
\hline 700 & $4.57 *$ & 9.48 & 17 & 2003 \\
\hline 700 & $4.57^{*}$ & 10.83 & 17 & 2003 \\
\hline 735 & 2 & 4.2 & 8 & 1976 \\
\hline 735 & 2 & 4.2 & 31 & 1980 \\
\hline 735 & 2 & 4.5 & 8 & 1976 \\
\hline 735 & 2 & 6.4 & 8 & 1976 \\
\hline 735 & 2 & 7.3 & 8 & 1976 \\
\hline 735 & 2 & 7.5 & 8 & 1976 \\
\hline 735 & 2.0 & 9.1 & 58 & 1975 \\
\hline 735 & 2 & $14^{\sigma}$ & 8 & 1976 \\
\hline 750 & 4 & $10^{\mathrm{S}}$ & 31 & 1980 \\
\hline
\end{tabular}


Table 2-4. All Calcination Temperature, Time, and SSA Data

\begin{tabular}{|c|c|c|c|c|}
\hline $\begin{array}{c}\text { Calcination } \\
\text { Temperature }\left[{ }^{\circ} \mathrm{C}\right]\end{array}$ & $\begin{array}{c}\text { Calcination Time } \\
{[\mathrm{h}]}\end{array}$ & $\mathrm{SSA}\left[\mathrm{m}^{2} / \mathrm{g}\right]$ & Reference & Year \\
\hline 750 & $8^{*}$ & 2 & 1 & 1996 \\
\hline 760 & 0.08 & 10.5 & 3 & 1995 \\
\hline 760 & 0.28 & 7.5 & 3 & 1995 \\
\hline 760 & 0.28 & 7.5 & 4 & 1961 \\
\hline 760 & 0.28 & 9.11 & 39 & 1964 \\
\hline 760 & 0.28 & 9.55 & 39 & 1964 \\
\hline 760 & 0.28 & 9.94 & 39 & 1964 \\
\hline 760 & 0.5 & 3.4 & 3 & 1995 \\
\hline 760 & 0.5 & 3.4 & 4 & 1961 \\
\hline 760 & 0.5 & 3.69 & 56 & 1963 \\
\hline 760 & 0.5 & 3.99 & 56 & 1963 \\
\hline 760 & 0.5 & 4.88 & 55 & 1963 \\
\hline 760 & 0.5 & 5.4 & 4 & 1961 \\
\hline 760 & 0.5 & 5.49 & 53 & 1962 \\
\hline 760 & 0.5 & 5.83 & 53 & 1962 \\
\hline 760 & 0.5 & 6.58 & 39 & 1964 \\
\hline 760 & 0.5 & 7.15 & 5 & 1961 \\
\hline 760 & 0.5 & 7.89 & 53 & 1962 \\
\hline 760 & 0.5 & 8.3 & 5 & 1961 \\
\hline 760 & 0.5 & 8.66 & 56 & 1963 \\
\hline 760 & NA & $9^{t}$ & 50 & 1961 \\
\hline 760 & 1.00 & 6.1 & 5 & 1961 \\
\hline 800 & 2.0 & 5.5 & 58 & 1975 \\
\hline 800 & 2.0 & 5.7 & 58 & 1975 \\
\hline 800 & 10 & 5.8 & 3 & 1995 \\
\hline 850 & $7.65^{*}$ & 2.6 & 1 & 1996 \\
\hline 900 & 1.3 & $5^{\mathrm{h}}$ & 25 & 1997 \\
\hline 950 & 2 & 2.7 & 3 & 1995 \\
\hline 950 & $3.89 *$ & 1.54 & 17 & 2003 \\
\hline 950 & $3.89^{*}$ & 1.65 & 17 & 2003 \\
\hline 950 & $3.89^{*}$ & 1.87 & 17 & 2003 \\
\hline 950 & $3.89 *$ & 1.88 & 17 & 2003 \\
\hline 950 & $7.37 *$ & 2.1 & 1 & 1996 \\
\hline 975 & $7.69 *$ & 1.09 & 13 & 2006 \\
\hline 1050 & 7.14* & 1.2 & 1 & 1996 \\
\hline 1100 & 2.0 & $<1$ & 58 & 1975 \\
\hline 1100 & 2.0 & $<1$ & 58 & 1975 \\
\hline
\end{tabular}

*estimated time value

${ }^{\mathrm{t}}$ missing time, ${ }^{\mathrm{p}}$ peroxide precipitation, ${ }^{\sigma}$ outside $\pm 3 \sigma$ limits, ${ }^{\mathrm{h}}$ mixed plutonium-uranium oxides calcined in 6 vol $\% \mathrm{H}_{2}-94 \mathrm{vol} \% \mathrm{~N}_{2}$, ${ }^{\mathrm{a}}$ average value of Ref 7 values, ${ }^{\mathrm{d}}$ duplicate ref. value, ${ }^{\mathrm{s}}$ calcined in steam so not used in correlation 


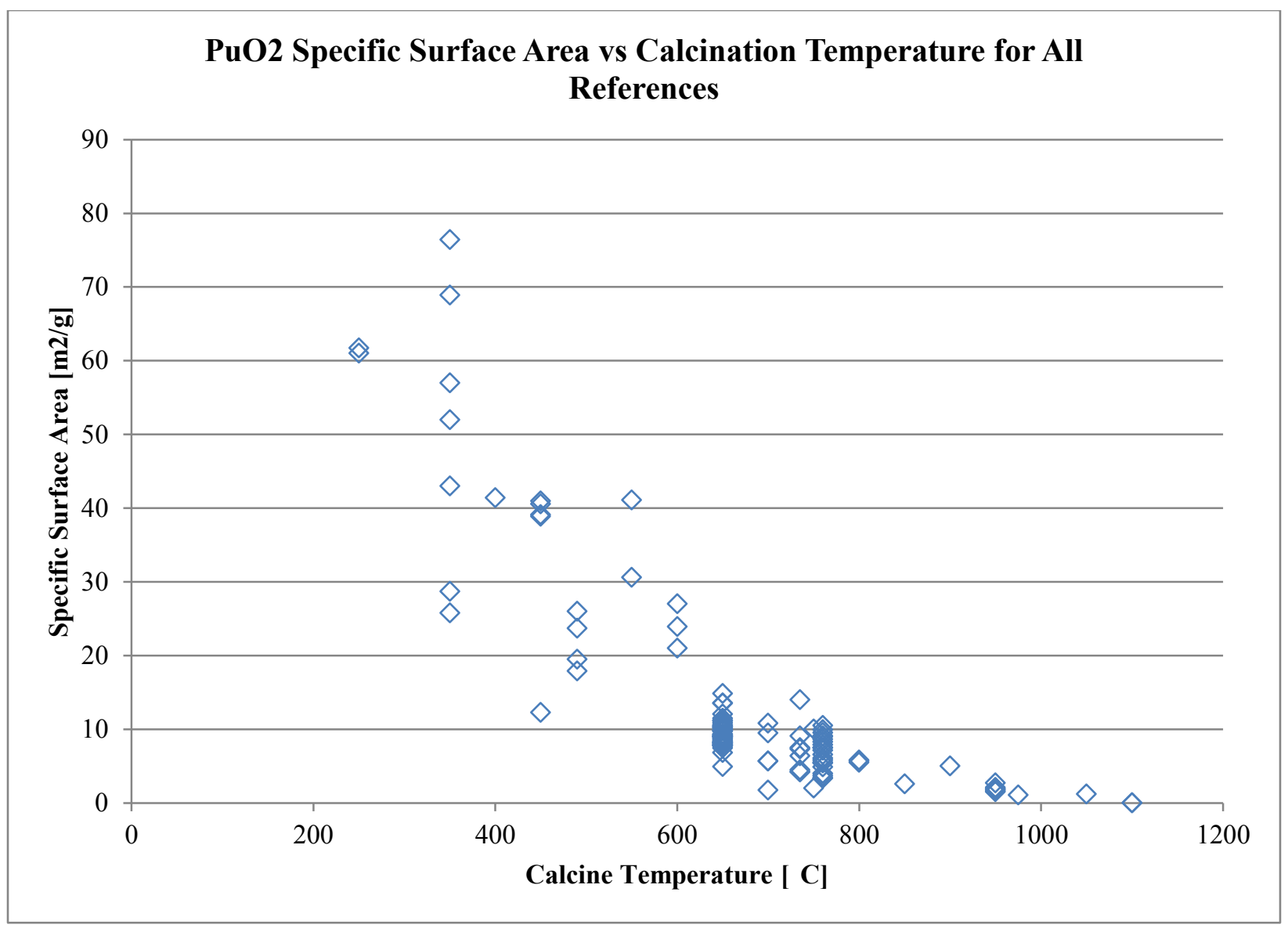

Figure 2-1. $\mathrm{PuO}_{2}$ Specific Surface Area vs Calcination Temperature for References

To try to identify the relation between calcination temperature and time of plutonium oxalate $\left(\mathrm{Pu}\left(\mathrm{C}_{2} \mathrm{O}_{4}\right)_{2}\right)$ on the specific surface area of the plutonium oxide $\left(\mathrm{PuO}_{2}\right)$ formed, some of the SSA data from the various references was excluded depending on how the $\mathrm{PuO}_{2}$ was being formed or based on like temperature/time data from the literature reviewed. Note that an * next to a calcination time means that it is an estimated value based on other times from this data set or how the sample was calcined. Should more correct calcination times be identified then the values can be updated. This refined set of data as shown in Table 2-5 will be used to try an empirical fit to examine the effect of calcination temperature and time of $\mathrm{Pu}\left(\mathrm{C}_{2} \mathrm{O}_{4}\right)_{2}$ on the specific surface area of $\mathrm{PuO}_{2}$ formed. Figure 2-2 is a plot of the calcination temperature versus the specific surface area data for the empirical fit. 
Table 2-5. Calcination Data of $\mathrm{Pu}\left(\mathrm{C}_{2} \mathrm{O}_{4}\right)_{2}$ to $\mathrm{PuO}_{2}$ used for Regression

\begin{tabular}{|c|c|c|c|c|}
\hline Calcination Temperature $\left[{ }^{\circ} \mathrm{C}\right]$ & Calcination Time $[\mathrm{h}]$ & $\mathrm{SSA}\left[\mathrm{m}^{2} / \mathrm{g}\right]$ & Reference & Year \\
\hline 250 & 2.0 & 61 & 58 & 1975 \\
\hline 250 & 2.0 & 61.7 & 58 & 1975 \\
\hline 350 & 0.25 & 52 & 5 & 1961 \\
\hline 350 & 0.50 & 43 & 4 & 1961 \\
\hline 350 & 1.0 & 28.7 & 49 & 1961 \\
\hline 350 & 2.0 & 68.9 & 58 & 1975 \\
\hline 350 & 2.0 & 76.4 & 58 & 1975 \\
\hline 350 & $2.1^{*}$ & 57 & 3 & 1995 \\
\hline 400 & $2.1^{*}$ & 41.4 & 30 & 1965 \\
\hline 450 & 4 & 38.88 & 17 & 2003 \\
\hline 450 & 4 & 39.09 & 17 & 2003 \\
\hline 450 & 4 & 40.56 & 17 & 2003 \\
\hline 450 & 4 & 40.97 & 17 & 2003 \\
\hline 550 & 2.0 & 30.6 & 58 & 1975 \\
\hline 550 & 2.0 & 41.1 & 58 & 1975 \\
\hline 600 & 6 & 21 & 13 & 2006 \\
\hline 600 & 3 & 27 & 31 & 1980 \\
\hline 600 & 12 & 23.9 & 3 & 1995 \\
\hline 650 & 4 & 4.93 & 7 & 2007 \\
\hline 650 & 4 & 10.18 & 7 & 2007 \\
\hline 650 & 4 & 9.76 & 7 & 2007 \\
\hline 650 & 4 & 10.54 & 7 & 2007 \\
\hline 650 & 4 & 10.86 & 7 & 2007 \\
\hline 650 & 4 & 7.89 & 7 & 2007 \\
\hline 650 & 4 & 8.47 & 7 & 2007 \\
\hline 650 & 4 & 9.29 & 7 & 2007 \\
\hline 650 & 4 & 8.64 & 7 & 2007 \\
\hline 650 & 4 & 9.08 & 7 & 2007 \\
\hline 650 & 4 & 8.30 & 7 & 2007 \\
\hline 650 & 4 & 10.31 & 7 & 2007 \\
\hline 650 & 4 & 10.23 & 7 & 2007 \\
\hline 650 & 4 & 8.91 & 7 & 2007 \\
\hline 650 & 4 & 13.56 & 7 & 2007 \\
\hline 650 & 4 & 11.50 & 7 & 2007 \\
\hline 650 & 4 & 10.37 & 7 & 2007 \\
\hline 650 & 4 & 8.04 & 7 & 2007 \\
\hline 650 & 4 & 9.07 & 7 & 2007 \\
\hline 650 & 4 & 8.90 & 7 & 2007 \\
\hline 650 & 4 & 10.54 & 7 & 2007 \\
\hline 650 & 4 & 12.04 & 7 & 2007 \\
\hline 650 & 4 & 13.51 & 7 & 2007 \\
\hline 650 & 4 & 11.14 & 7 & 2007 \\
\hline 650 & 4 & 8.35 & 7 & 2007 \\
\hline 650 & 4 & 8.11 & 7 & 2007 \\
\hline 650 & 4 & 9.82 & 7 & 2007 \\
\hline 650 & 4 & 11.20 & 7 & 2007 \\
\hline
\end{tabular}


Table 2-5. Calcination Data of $\mathrm{Pu}\left(\mathrm{C}_{2} \mathrm{O}_{4}\right)_{2}$ to $\mathrm{PuO}_{2}$ used for Regression

\begin{tabular}{|c|c|c|c|c|}
\hline Calcination Temperature $\left[{ }^{\circ} \mathrm{C}\right]$ & Calcination Time $[\mathrm{h}]$ & $\mathrm{SSA}\left[\mathrm{m}^{2} / \mathrm{g}\right]$ & Reference & Year \\
\hline 650 & 4 & 6.85 & 7 & 2007 \\
\hline 650 & 4 & 7.45 & 7 & 2007 \\
\hline 650 & 4 & 7.70 & 7 & 2007 \\
\hline 650 & 4 & 7.82 & 7 & 2007 \\
\hline 650 & 4 & 8.11 & 7 & 2007 \\
\hline 650 & 4 & 8.22 & 7 & 2007 \\
\hline 650 & 4 & 7.87 & 7 & 2007 \\
\hline 650 & 4 & 8.75 & 7 & 2007 \\
\hline 650 & 4 & 9.01 & 7 & 2007 \\
\hline 650 & 4 & 9.89 & 7 & 2007 \\
\hline 650 & 4 & 9.07 & 7 & 2007 \\
\hline 650 & 4 & 7.77 & 7 & 2007 \\
\hline 650 & 4 & 8.19 & 7 & 2007 \\
\hline 650 & 4 & 9.07 & 7 & 2007 \\
\hline 650 & 4 & 9.37 & 7 & 2007 \\
\hline 650 & 4 & 9.26 & 7 & 2007 \\
\hline 650 & 4 & 14.86 & 7 & 2007 \\
\hline 650 & $8.46^{*}$ & 7.9 & 1 & 1996 \\
\hline 700 & $4.57^{*}$ & 9.48 & 17 & 2003 \\
\hline 700 & $4.57 *$ & 10.83 & 17 & 2003 \\
\hline 700 & 12 & 5.7 & 3 & 1995 \\
\hline 735 & 2 & 4.2 & 8 & 1976 \\
\hline 735 & 2 & 4.2 & 31 & 1980 \\
\hline 735 & 2 & 4.5 & 8 & 1976 \\
\hline 735 & 2 & 6.4 & 8 & 1976 \\
\hline 735 & 2 & 7.3 & 8 & 1976 \\
\hline 735 & 2 & 7.5 & 8 & 1976 \\
\hline 735 & 2.0 & 9.1 & 58 & 1975 \\
\hline 750 & $8^{*}$ & 2 & 1 & 1996 \\
\hline 760 & 0.08 & 10.5 & 3 & 1995 \\
\hline 760 & 0.28 & 7.5 & 3 & 1995 \\
\hline 760 & 0.28 & 7.5 & 4 & 1961 \\
\hline 760 & 0.28 & 9.11 & 39 & 1964 \\
\hline 760 & 0.28 & 9.55 & 39 & 1964 \\
\hline 760 & 0.28 & 9.94 & 39 & 1964 \\
\hline 760 & 0.5 & 3.4 & 3 & 1995 \\
\hline 760 & 0.5 & 3.4 & 4 & 1961 \\
\hline 760 & 0.5 & 3.69 & 56 & 1963 \\
\hline 760 & 0.5 & 3.99 & 56 & 1963 \\
\hline 760 & 0.5 & 4.88 & 55 & 1963 \\
\hline 760 & 0.5 & 5.4 & 4 & 1961 \\
\hline 760 & 0.5 & 5.49 & 53 & 1962 \\
\hline 760 & 0.5 & 5.83 & 53 & 1962 \\
\hline 760 & 0.50 & 6.58 & 39 & 1964 \\
\hline 760 & 0.50 & 7.15 & 5 & 1961 \\
\hline 760 & 0.5 & 7.89 & 53 & 1962 \\
\hline
\end{tabular}


Table 2-5. Calcination Data of $\mathrm{Pu}\left(\mathrm{C}_{2} \mathrm{O}_{4}\right)_{2}$ to $\mathrm{PuO}_{2}$ used for Regression

\begin{tabular}{|c|c|c|c|c|}
\hline Calcination Temperature $\left[{ }^{\circ} \mathrm{C}\right]$ & Calcination Time $[\mathrm{h}]$ & $\mathrm{SSA}\left[\mathrm{m}^{2} / \mathrm{g}\right]$ & Reference & Year \\
\hline 760 & 0.5 & 8.3 & 5 & 1961 \\
\hline 760 & 0.5 & 8.66 & 56 & 1963 \\
\hline 760 & 1.00 & 6.1 & 5 & 1961 \\
\hline 800 & 2.0 & 5.5 & 58 & 1975 \\
\hline 800 & 2.0 & 5.7 & 58 & 1975 \\
\hline 800 & 10 & 5.8 & 3 & 1995 \\
\hline 850 & $7.65^{*}$ & 2.6 & 1 & 1996 \\
\hline 950 & 2 & 2.7 & 3 & 1995 \\
\hline 950 & $3.89^{*}$ & 1.54 & 17 & 2003 \\
\hline 950 & $3.89^{*}$ & 1.65 & 17 & 2003 \\
\hline 950 & $3.89^{*}$ & 1.87 & 17 & 2003 \\
\hline 950 & $3.89^{*}$ & 1.88 & 17 & 2003 \\
\hline 950 & $7.37^{*}$ & 2.1 & 1 & 1996 \\
\hline 975 & $7.69^{*}$ & 1.09 & 13 & 2006 \\
\hline 1050 & $7.14^{*}$ & 1.2 & 1 & 1996 \\
\hline 1100 & 2.0 & $1^{* *}$ & 58 & 1975 \\
\hline 1100 & 2.0 & $1 * *$ & 58 & 1975 \\
\hline
\end{tabular}

*estimated time value, ${ }^{* *}$ Treat $<1$ values as 1 for fits

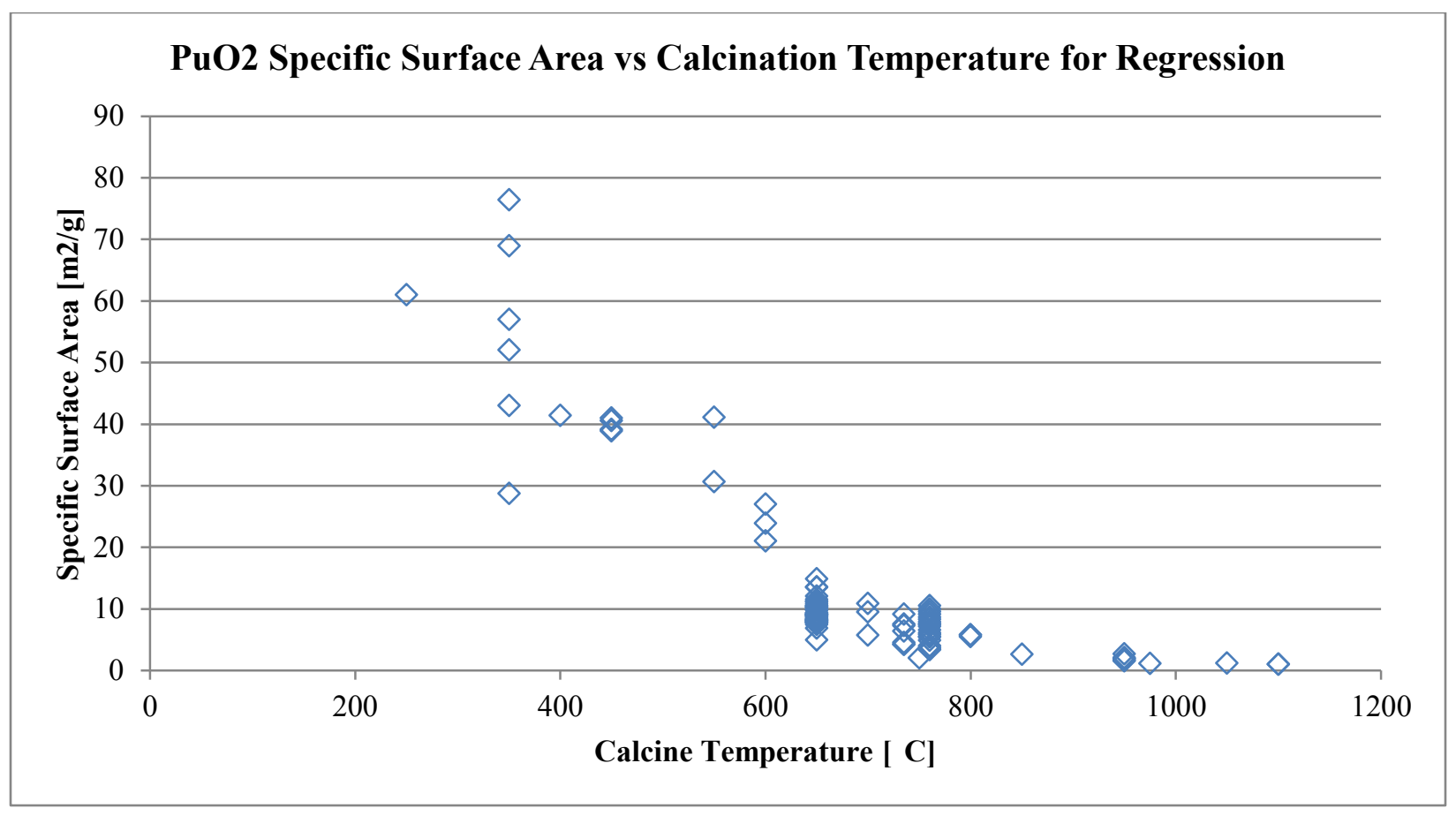

Figure 2-2. $\mathrm{PuO}_{2}$ Specific Surface Area vs Calcination Temperature for Regression 
SRNL-TR-2011-00334

Revision 0

\subsection{Results and Discussion}

\subsection{Preliminary Regression of $250-1100{ }^{\circ} \mathrm{C}$ Calcination and Time Data for $\mathrm{PuO}_{2}$ from $\mathrm{Pu}\left(\mathrm{C}_{2} \underline{\mathrm{O}}_{4}\right)_{2}$}

To try to understand the effect of calcination temperature and time of plutonium oxalate $\left(\mathrm{Pu}\left(\mathrm{C}_{2} \mathrm{O}_{4}\right)_{2}\right)$ on the specific surface area of the formation of $\mathrm{PuO}_{2}$, the refined data from the literature review in Table 2-5 was imported into the curve fitting program Table Curve 3D version 4.0. Note that this is only a preliminary fit of the data and should be refined as more information or data becomes available. After looking at the various fits that Table Curve 3D derived with and using various knowledge of how the SSA changes with temperature and time, the following equation was chosen:

$$
\begin{gathered}
\text { Eqn 3-1 SSA=A+B*EXP }-0.5 * \frac{T E M P-C}{D}^{2}+E * E X P-0.5 * \frac{T I M E-F}{G}^{2}+ \\
H * E X P-0.5 * \frac{T E M P-C^{2}}{D}+{\frac{T I M E-F^{2}}{G}}^{2}
\end{gathered}
$$

where:

$$
\begin{gathered}
\text { SSA Specific Surface Area of the } \mathrm{PuO}_{2} \text { from } \mathrm{Pu}\left(\mathrm{C}_{2} \mathrm{O}_{4}\right)_{2}, \mathrm{~m}^{2} / \mathrm{g} \\
\text { TEMP }=\text { Calcination Temperature in }{ }^{\circ} \mathrm{C} \\
\text { TIME }=\text { Calcination Time in hours } \\
\mathrm{A}=2.5080 \mathrm{E}+00, \text { Empirical Fit Parameter } \\
\mathrm{B}=4.2241 \mathrm{E}+01, \text { Empirical Fit Parameter } \\
\mathrm{C}=3.1099 \mathrm{E}+02, \text { Empirical Fit Parameter } \\
\mathrm{D}=1.8485 \mathrm{E}+02, \text { Empirical Fit Parameter } \\
\mathrm{E}=-3.9178 \mathrm{E}-01 \text {, Empirical Fit Parameter } \\
\mathrm{F}=2.5971 \mathrm{E}+00, \text { Empirical Fit Parameter } \\
\mathrm{G}=6.4387 \mathrm{E}-01, \text { Empirical Fit Parameter } \\
\mathrm{H}=2.9805 \mathrm{E}+01, \text { Empirical Fit Parameter } \\
\text { EXP }=\text { exponential function }
\end{gathered}
$$

Using this preliminary fit, the SSA is predicted for the various calcination temperature and time data points of plutonium oxalate $\left(\mathrm{Pu}\left(\mathrm{C}_{2} \mathrm{O}_{4}\right)_{2}\right)$ from Table 2-5 and shown in Table 3-1. A 2D representation of this empirical fit for the full temperature range of 250 to $1100{ }^{\circ} \mathrm{C}$ is shown in Figure 3-1 where the predicted SSA values are shown as lines and the observed SSA values are shown as symbols. The empirical fit shows that the calcination temperature has a bigger effect than time on SSA. The fit also shows that at lower temperatures $\left(<450^{\circ} \mathrm{C}\right)$ the calcination time has a bigger effect on SSA than at higher temperatures $\left(>650^{\circ} \mathrm{C}\right)$. Figure 3-2 shows an enlarged section of the fit between $600{ }^{\circ} \mathrm{C}$ and $700{ }^{\circ} \mathrm{C}$ noting that there are only observed SSA data points at $600{ }^{\circ} \mathrm{C}, 650^{\circ} \mathrm{C}$, and $700^{\circ} \mathrm{C}$ at certain calcination times. To better visualize this preliminary fit, the 3D plots from Table Curve 3D have been captured and pasted into this report. Figure 3-3 through Figure 3-7 show the plots of the observed SSA values (the round data points in the figures) versus the preliminary regression (the colored red to blue surface) from Eqn 3-1. There is a slight bump in the SSA surface at the low calcination temperatures $\left(250-350^{\circ} \mathrm{C}\right)$ and low times ( $0-3$ hours) which is a reflection of what References 5 and 58 refer to as a breakdown of the crystallite structure of $\mathrm{Pu}\left(\mathrm{C}_{2} \mathrm{O}_{4}\right)_{2}$ and the escape of decomposition gases as the material transforms into plutonium oxide. This transition from $\mathrm{Pu}\left(\mathrm{C}_{2} \mathrm{O}_{4}\right)_{2}$ to $\mathrm{PuO}_{2}$ is shown in Figure 3-1 as the specific surface area goes up at $350{ }^{\circ} \mathrm{C}$ from 1 to 2 hours but then decreases at 3 hours. 
Table 3-1. Calcination Data of $\mathrm{Pu}\left(\mathrm{C}_{2} \mathrm{O}_{4}\right)_{2}$ to $\mathrm{PuO}_{2}$ for Regression of SSA

\begin{tabular}{|c|c|c|c|}
\hline Calcination Temperature $\left[{ }^{\circ} \mathrm{C}\right]$ & Calcination Time $[\mathrm{h}]$ & SSA Observed $\left[\mathrm{m}^{2} / \mathrm{g}\right]$ & SSA Predicted $\left[\mathrm{m}^{2} / \mathrm{g}\right]$ \\
\hline 250 & 2.0 & 61 & 61 \\
\hline 250 & 2.0 & 61.7 & 61 \\
\hline 350 & 0.25 & 52 & 44 \\
\hline 350 & 0.50 & 43 & 44 \\
\hline 350 & 1.0 & 28.7 & 45 \\
\hline 350 & 2.0 & 68.9 & 63 \\
\hline 350 & 2.0 & 76.4 & 63 \\
\hline 350 & $2.1^{*}$ & 57 & 65 \\
\hline 400 & $2.1^{*}$ & 41.4 & 60 \\
\hline 450 & 4 & 38.88 & 36 \\
\hline 450 & 4 & 39.09 & 36 \\
\hline 450 & 4 & 40.56 & 36 \\
\hline 450 & 4 & 40.97 & 36 \\
\hline 550 & 2.0 & 30.6 & 29 \\
\hline 550 & 2.0 & 41.1 & 29 \\
\hline 600 & 6 & 21 & 15 \\
\hline 600 & 3 & 27 & 22 \\
\hline 600 & 12 & 23.9 & 15 \\
\hline 650 & 4 & 4.93 & 11 \\
\hline 650 & 4 & 10.18 & 11 \\
\hline 650 & 4 & 9.76 & 11 \\
\hline 650 & 4 & 10.54 & 11 \\
\hline 650 & 4 & 10.86 & 11 \\
\hline 650 & 4 & 7.89 & 11 \\
\hline 650 & 4 & 8.47 & 11 \\
\hline 650 & 4 & 9.29 & 11 \\
\hline 650 & 4 & 8.64 & 11 \\
\hline 650 & 4 & 9.08 & 11 \\
\hline 650 & 4 & 8.30 & 11 \\
\hline 650 & 4 & 10.31 & 11 \\
\hline 650 & 4 & 10.23 & 11 \\
\hline 650 & 4 & 8.91 & 11 \\
\hline 650 & 4 & 13.56 & 11 \\
\hline 650 & 4 & 11.50 & 11 \\
\hline 650 & 4 & 10.37 & 11 \\
\hline 650 & 4 & 8.04 & 11 \\
\hline 650 & 4 & 9.07 & 11 \\
\hline 650 & 4 & 8.90 & 11 \\
\hline 650 & 4 & 10.54 & 11 \\
\hline 650 & 4 & 12.04 & 11 \\
\hline 650 & 4 & 13.51 & 11 \\
\hline 650 & 4 & 11.14 & 11 \\
\hline 650 & 4 & 8.35 & 11 \\
\hline 650 & 4 & 8.11 & 11 \\
\hline 650 & 4 & 9.82 & 11 \\
\hline
\end{tabular}


Table 3-1. Calcination Data of $\mathrm{Pu}\left(\mathrm{C}_{2} \mathrm{O}_{4}\right)_{2}$ to $\mathrm{PuO}_{2}$ for Regression of SSA

\begin{tabular}{|c|c|c|c|}
\hline Calcination Temperature $\left[{ }^{\circ} \mathrm{C}\right]$ & Calcination Time $[\mathrm{h}]$ & SSA Observed $\left[\mathrm{m}^{2} / \mathrm{g}\right]$ & SSA Predicted $\left[\mathrm{m}^{2} / \mathrm{g}\right]$ \\
\hline 650 & 4 & 11.20 & 11 \\
\hline 650 & 4 & 6.85 & 11 \\
\hline 650 & 4 & 7.45 & 11 \\
\hline 650 & 4 & 7.70 & 11 \\
\hline 650 & 4 & 7.82 & 11 \\
\hline 650 & 4 & 8.11 & 11 \\
\hline 650 & 4 & 8.22 & 11 \\
\hline 650 & 4 & 7.87 & 11 \\
\hline 650 & 4 & 8.75 & 11 \\
\hline 650 & 4 & 9.01 & 11 \\
\hline 650 & 4 & 9.89 & 11 \\
\hline 650 & 4 & 9.07 & 11 \\
\hline 650 & 4 & 7.77 & 11 \\
\hline 650 & 4 & 8.19 & 11 \\
\hline 650 & 4 & 9.07 & 11 \\
\hline 650 & 4 & 9.37 & 11 \\
\hline 650 & 4 & 9.26 & 11 \\
\hline 650 & 4 & 14.86 & 11 \\
\hline 650 & $8.46^{*}$ & 7.9 & 10 \\
\hline 700 & $4.57 *$ & 9.48 & 7 \\
\hline 700 & $4.57^{*}$ & 10.83 & 7 \\
\hline 700 & 12 & 5.7 & 7 \\
\hline 735 & 2 & 4.2 & 7 \\
\hline 735 & 2 & 4.2 & 7 \\
\hline 735 & 2 & 4.5 & 7 \\
\hline 735 & 2 & 6.4 & 7 \\
\hline 735 & 2 & 7.3 & 7 \\
\hline 735 & 2 & 7.5 & 7 \\
\hline 735 & 2.0 & 9.1 & 7 \\
\hline 750 & $8^{*}$ & 2 & 5 \\
\hline 760 & 0.08 & 10.5 & 5 \\
\hline 760 & 0.28 & 7.5 & 5 \\
\hline 760 & 0.28 & 7.5 & 5 \\
\hline 760 & 0.28 & 9.11 & 5 \\
\hline 760 & 0.28 & 9.55 & 5 \\
\hline 760 & 0.28 & 9.94 & 5 \\
\hline 760 & 0.5 & 3.4 & 5 \\
\hline 760 & 0.5 & 3.4 & 5 \\
\hline 760 & 0.5 & 3.69 & 5 \\
\hline 760 & 0.5 & 3.99 & 5 \\
\hline 760 & 0.5 & 4.88 & 5 \\
\hline 760 & 0.5 & 5.4 & 5 \\
\hline 760 & 0.5 & 5.49 & 5 \\
\hline 760 & 0.5 & 5.83 & 5 \\
\hline 760 & 0.50 & 6.58 & 5 \\
\hline
\end{tabular}


Table 3-1. Calcination Data of $\mathrm{Pu}\left(\mathrm{C}_{2} \mathrm{O}_{4}\right)_{2}$ to $\mathrm{PuO}_{2}$ for Regression of SSA

\begin{tabular}{|c|c|c|c|}
\hline Calcination Temperature $\left[{ }^{\circ} \mathrm{C}\right]$ & Calcination Time $[\mathrm{h}]$ & SSA Observed $\left[\mathrm{m}^{2} / \mathrm{g}\right]$ & SSA Predicted $\left[\mathrm{m}^{2} / \mathrm{g}\right]$ \\
\hline 760 & 0.50 & 7.15 & 5 \\
\hline 760 & 0.5 & 7.89 & 5 \\
\hline 760 & 0.5 & 8.3 & 5 \\
\hline 760 & 0.5 & 8.66 & 5 \\
\hline 760 & 1.00 & 6.1 & 5 \\
\hline 800 & 2.0 & 5.5 & 4 \\
\hline 800 & 2.0 & 5.7 & 4 \\
\hline 800 & 10 & 5.8 & 4 \\
\hline 850 & $7.65^{*}$ & 2.6 & 2 \\
\hline 950 & 2 & 2.7 & 3 \\
\hline 950 & $3.89^{*}$ & 1.54 & 3 \\
\hline 950 & $3.89^{*}$ & 1.65 & 3 \\
\hline 950 & $3.89^{*}$ & 1.87 & 3 \\
\hline 950 & $3.89^{*}$ & 1.88 & 3 \\
\hline 950 & $7.37^{*}$ & 2.1 & 3 \\
\hline 975 & $7.69^{*}$ & 1.09 & 2 \\
\hline 1050 & $7.14^{*}$ & 1.2 & 2 \\
\hline 1100 & 2.0 & $1^{* *}$ & $1 * *$ \\
\hline 1100 & 2.0 & 1.1 & \\
\hline
\end{tabular}

*estimated time value, ${ }^{* *}$ Treat $<1$ values as 1 for fits 


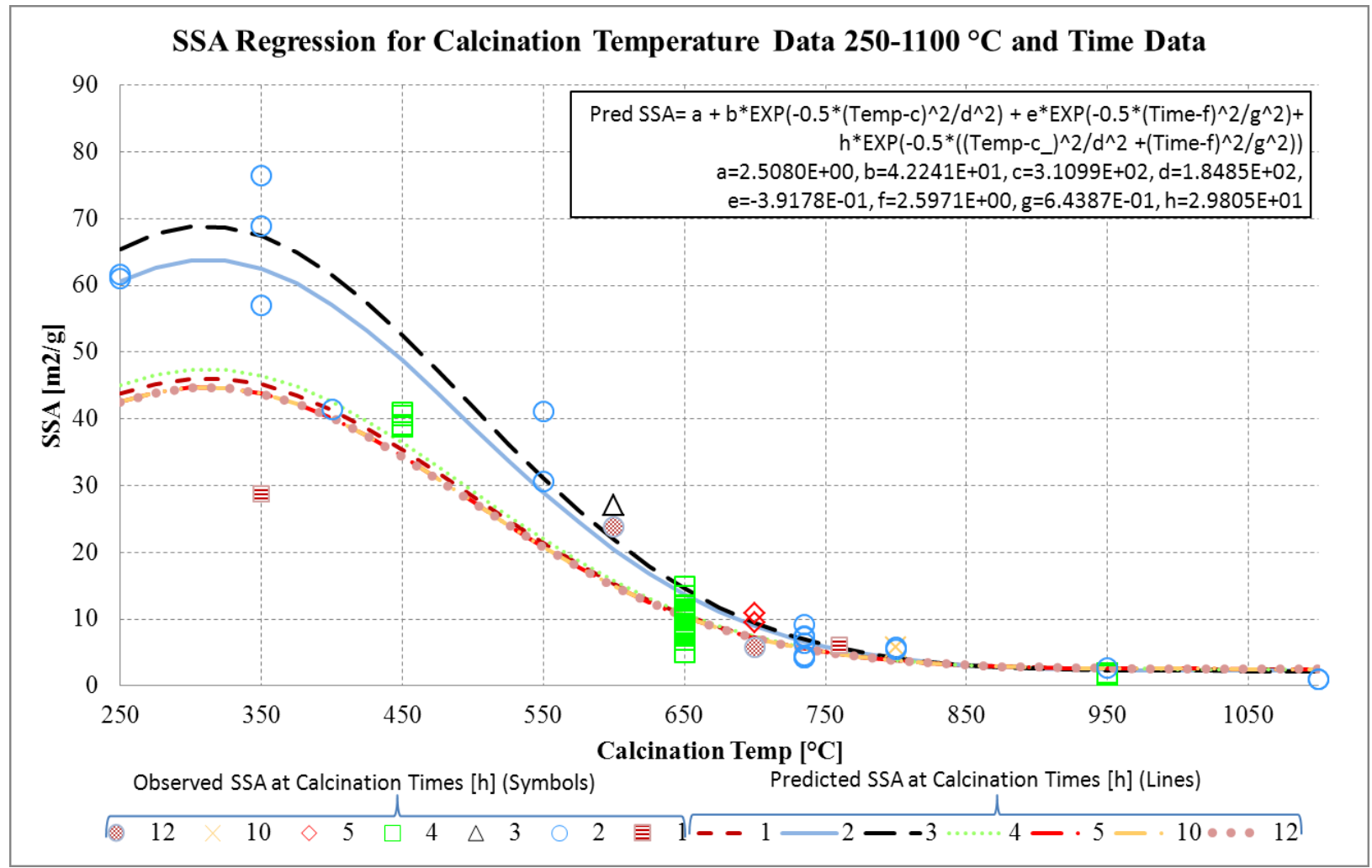

Figure 3-1. PuO2 from oxalate-Correlation of SSA to Calcination Temp. $\left(250-1100{ }^{\circ} \mathrm{C}\right)$ and Time-2D View 1

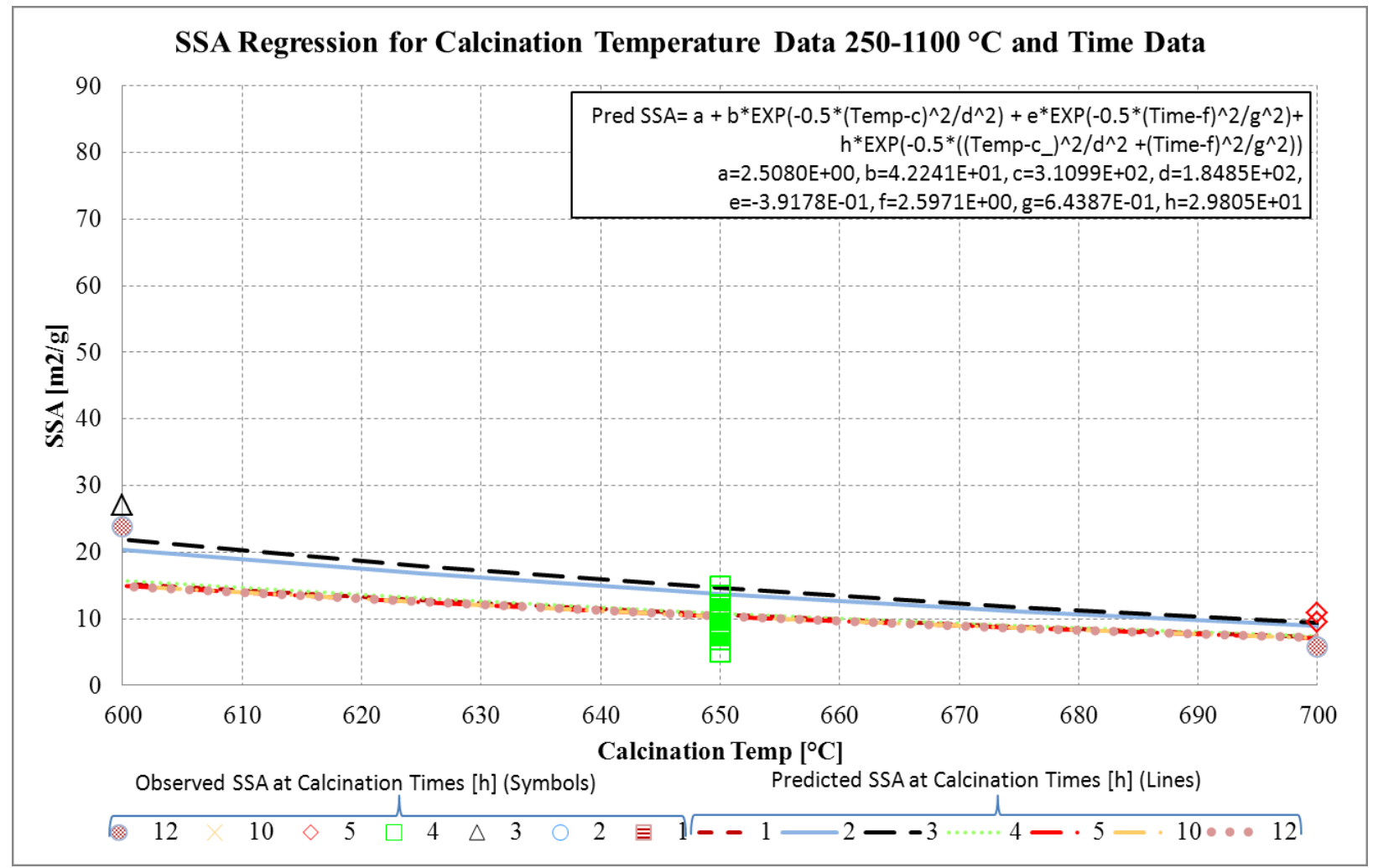

Figure 3-2. $\mathrm{PuO}_{2}$ from oxalate-Correlation of SSA to Calcination Temp. $\left(250-1100{ }^{\circ} \mathrm{C}\right)$ and Time-2D View 2 


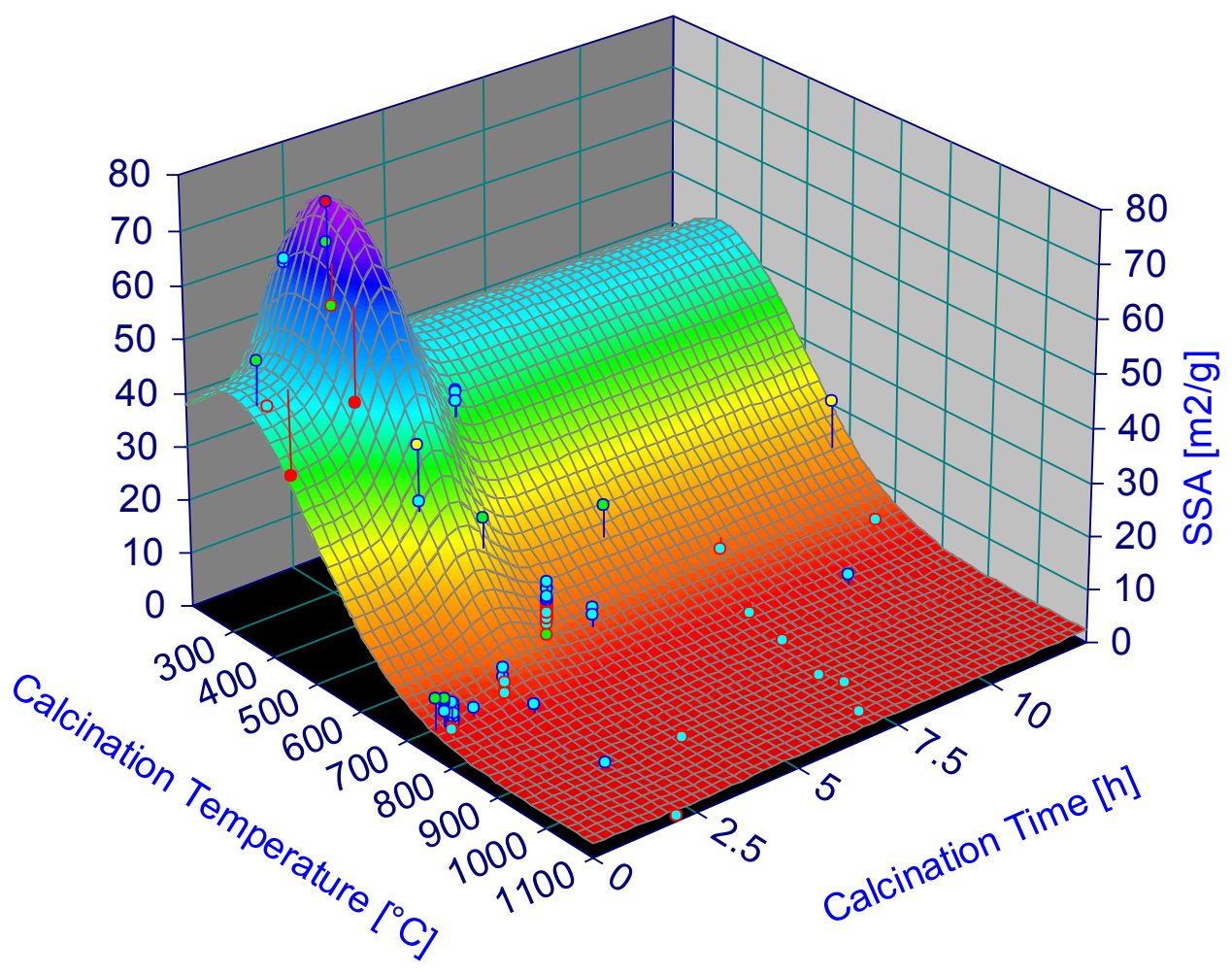

Figure 3-3. $\mathrm{PuO}_{2}$ from oxalate-Correlation of SSA to Calcination Temp. $\left(250-1100{ }^{\circ} \mathrm{C}\right)$ and Time-3D View 1

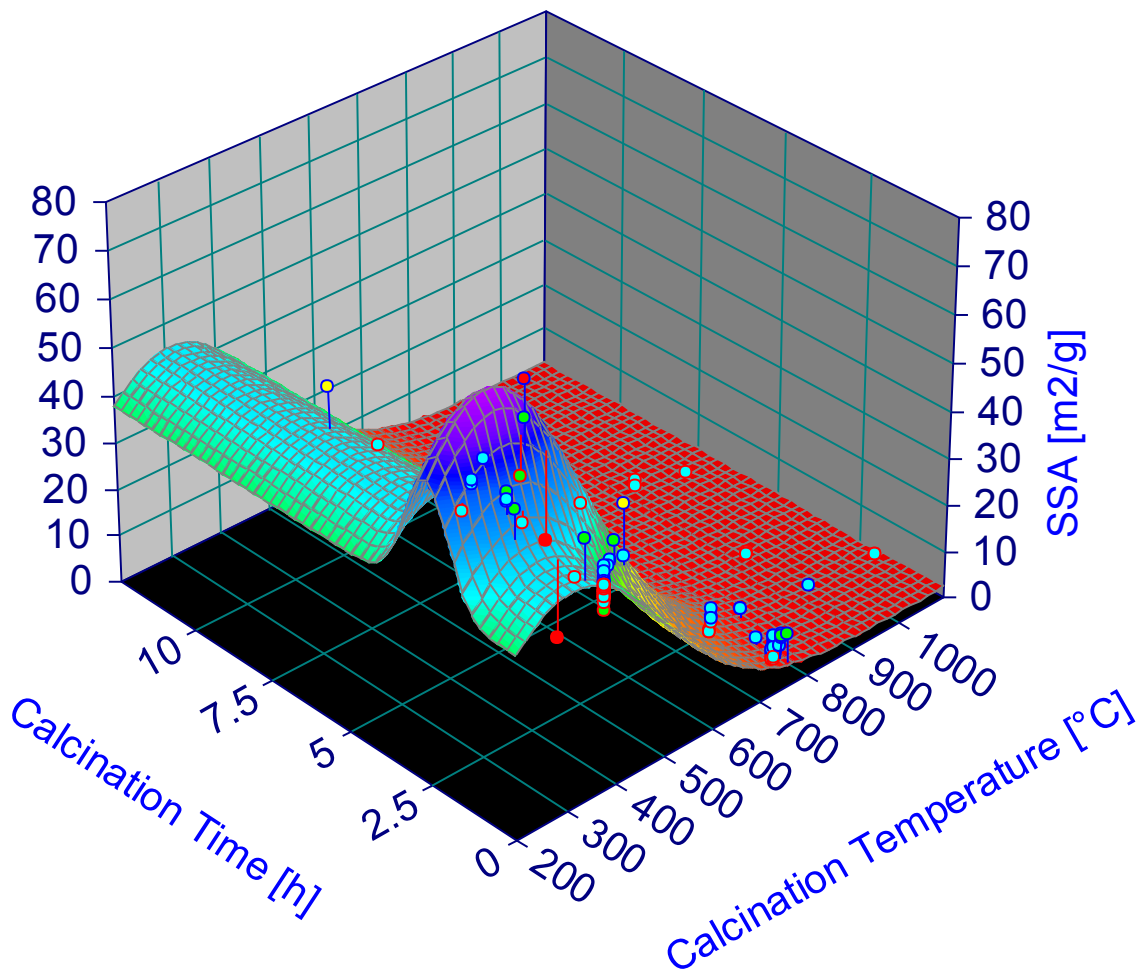

Figure 3-4. $\mathrm{PuO}_{2}$ from oxalate-Correlation of SSA to Calcination Temp. $\left(250-1100{ }^{\circ} \mathrm{C}\right)$ and Time-3D View 2 


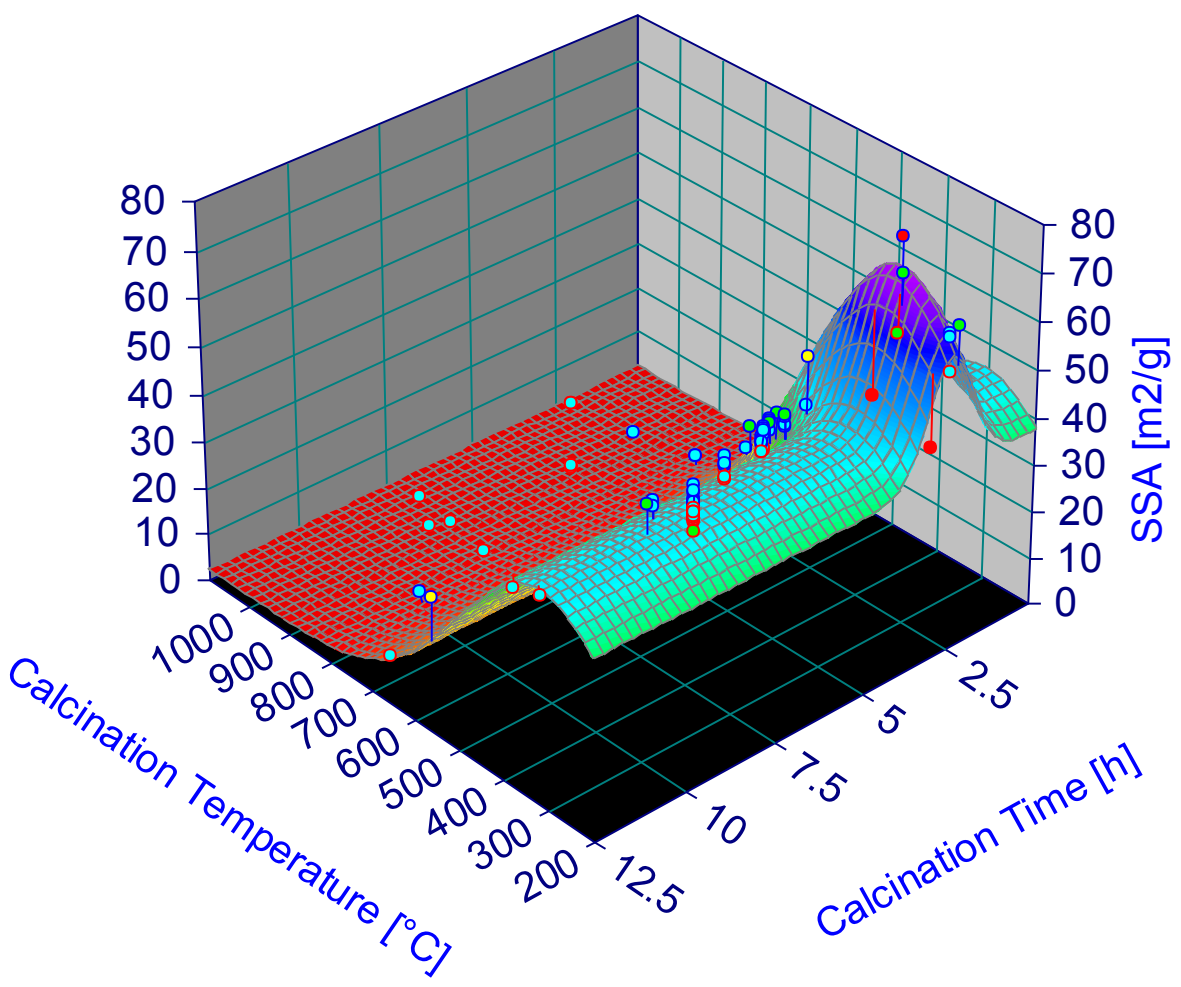

Figure 3-5. $\mathrm{PuO}_{2}$ from oxalate-Correlation of SSA to Calcination Temp. $\left(250-1100{ }^{\circ} \mathrm{C}\right)$ and Time-3D View 3

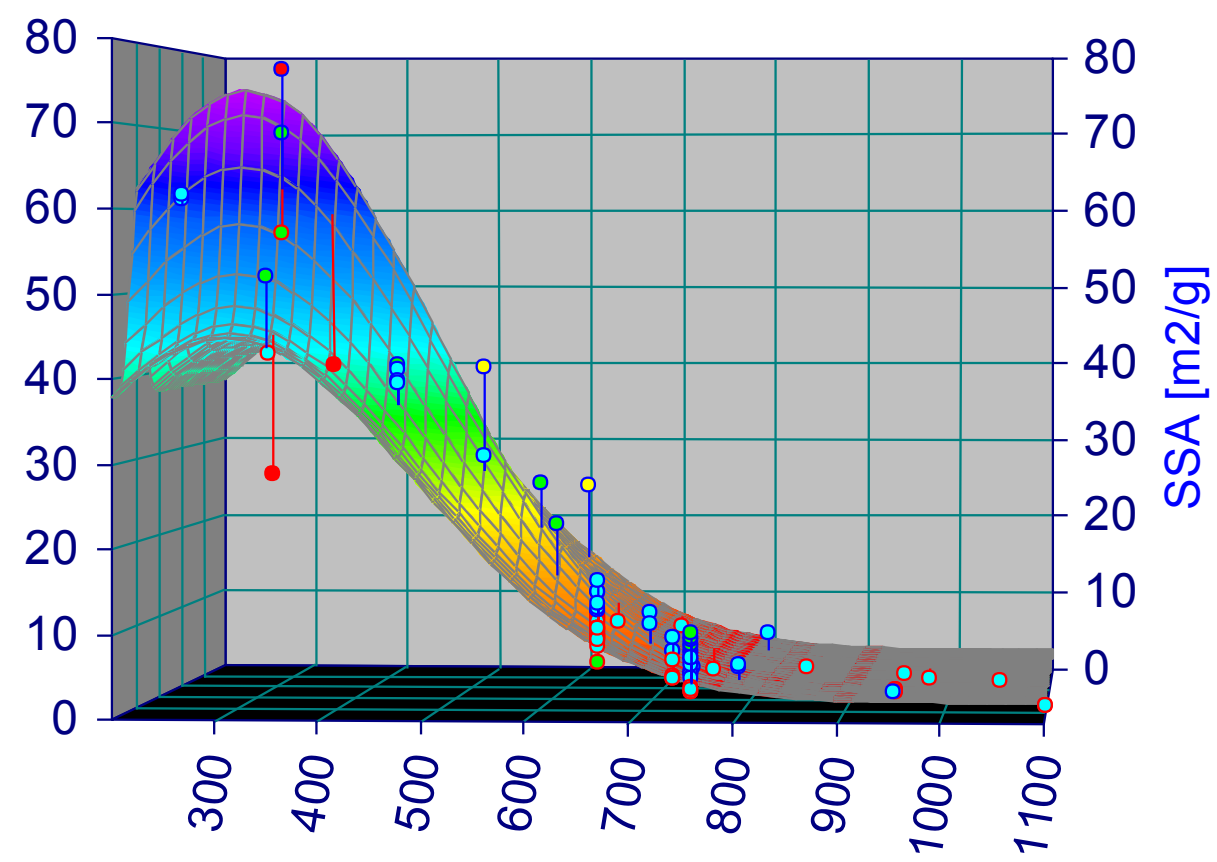

\section{Calcination Temperature $\left[{ }^{\circ} \mathrm{C}\right]$}

Figure 3-6. $\mathrm{PuO}_{2}$ from oxalate-Correlation of SSA to Calcination Temp. $\left(250-1100{ }^{\circ} \mathrm{C}\right)$ and Time-3D View 4 


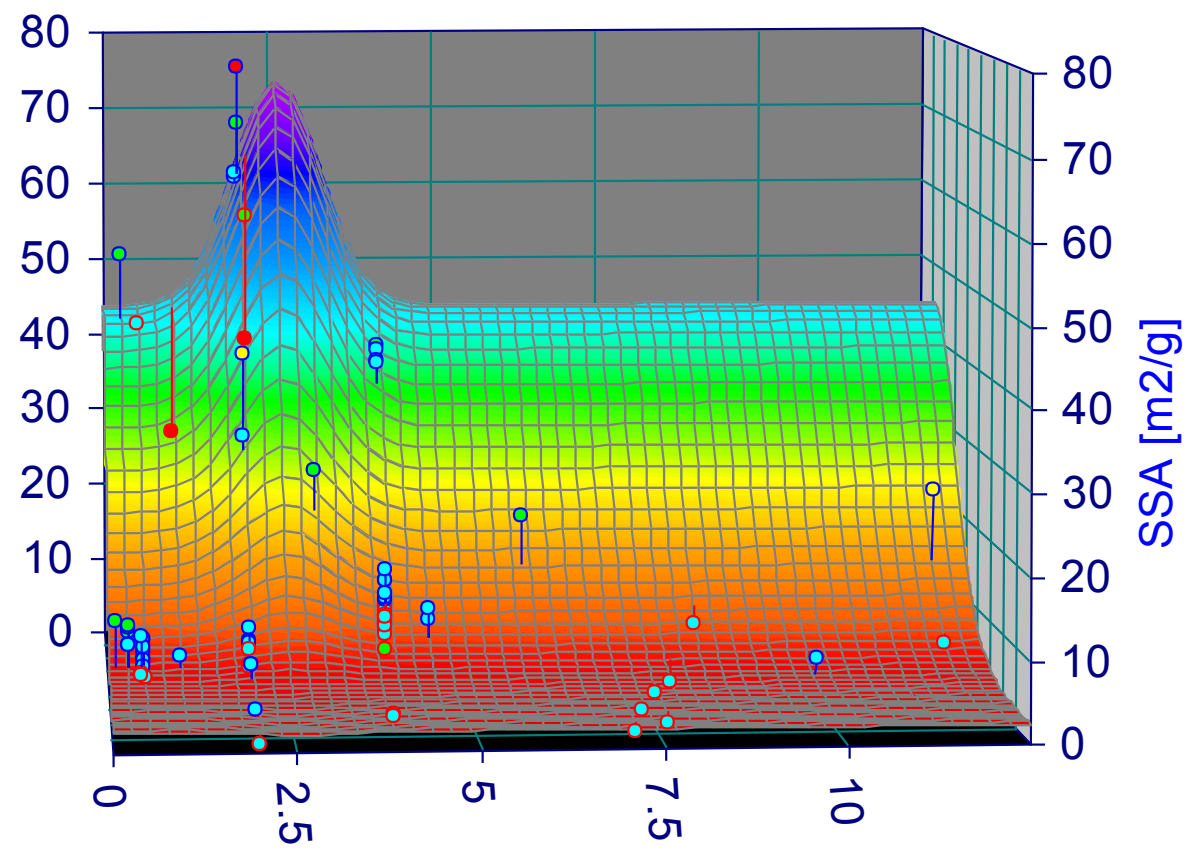

Calcination Time $[\mathrm{h}]$

Figure 3-7. $\mathrm{PuO}_{2}$ from oxalate-Correlation of SSA to Calcination Temp. $\left(250-1100{ }^{\circ} \mathrm{C}\right)$ and Time-3D View 5

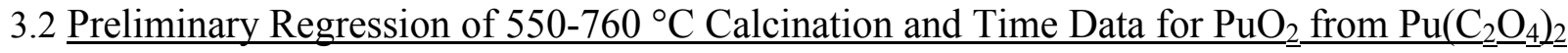

Since the temperature range of current interest is between 600 and $700{ }^{\circ} \mathrm{C}$, another regression was performed but restricting the calcination temperature and time data to 550 to $760{ }^{\circ} \mathrm{C}$ from Table 2-5. Note that this refined regression should not be used outside the temperature range of $550{ }^{\circ} \mathrm{C}$ and $760{ }^{\circ} \mathrm{C}$ otherwise might get unreasonable predictions. Table Curve 3D version 4.0 was again used to find an appropriate correlation. Note that this is only a preliminary fit of the data and should be refined as more information or data becomes available. After looking at the various correlations from Table Curve 3D and using knowledge of how the SSA changes with temperature and time, the following equation was chosen:

$$
\begin{aligned}
& \text { Eqn 3-2 } S S A=A+\frac{B}{T E M P}+\frac{C}{T E M P^{1.5}}+D \cdot \frac{L N T E M P}{T E M P^{2}}+\frac{E}{T e m p^{2}}+F \cdot \text { Time }^{0.5} \cdot \text { LN Time }^{2}+ \\
& \text { where: } \\
& G \cdot \text { Time }^{0.5}+H \cdot L N \text { Time }+\frac{I}{\text { TIME }^{0.5}}
\end{aligned}
$$

$$
\begin{gathered}
\mathrm{SSA}=\text { Specific Surface Area of the } \mathrm{PuO}_{2} \text { from } \mathrm{Pu}\left(\mathrm{C}_{2} \mathrm{O}_{4}\right)_{2}, \mathrm{~m}^{2} / \mathrm{g} \\
\text { TEMP }=\text { Calcination Temperature in }{ }^{\circ} \mathrm{C} \\
\text { TIME }=\text { Calcination Time in hours } \\
\mathrm{A}=-1.4972 \mathrm{E}+05, \text { Empirical Fit Parameter } \\
\mathrm{B}=1.1665 \mathrm{E}+09, \text { Empirical Fit Parameter }
\end{gathered}
$$


SRNL-TR-2011-00334

Revision 0

$\mathrm{C}=-7.9140 \mathrm{E}+10$, Empirical Fit Parameter

$\mathrm{D}=3.7702 \mathrm{E}+11$, Empirical Fit Parameter

$\mathrm{E}=-1.1193 \mathrm{E}+12$, Empirical Fit Parameter

$\mathrm{F}=-1.2105 \mathrm{E}+01$, Empirical Fit Parameter

$\mathrm{G}=7.1417 \mathrm{E}+01$, Empirical Fit Parameter

$\mathrm{H}=-3.5063 \mathrm{E}+01$, Empirical Fit Parameter

$\mathrm{I}=-1.5101 \mathrm{E}+01$, Empirical Fit Parameter

$\mathrm{LN}=$ Natural Logarithm

Using this equation, the SSA is predicted for the various calcination temperature and time data points of plutonium oxalate $\left(\mathrm{Pu}\left(\mathrm{C}_{2} \mathrm{O}_{4}\right)_{2}\right)$ from Table 2-5 and shown in Table 3-2. A 2D representation of this empirical fit for the temperature range of 550 to $760{ }^{\circ} \mathrm{C}$ is shown in Figure 3-8. The empirical fit has more curvature in it when just fitting the SSA data points between 550 and $760{ }^{\circ} \mathrm{C}$. As done in the prior analysis, the lines in Figure 3-8 represent the SSA predicted values for various calcination times and the symbols represent the observed SSA values. The equation does a fair job representing the observed SSA values over the various times. Figure 3-9 shows an enlarged section of the fit between $600{ }^{\circ} \mathrm{C}$ and $700{ }^{\circ} \mathrm{C}$ noting that the observed SSA data points in this range is small. The sparseness of the data in this range indicates the need to obtain more data to further refine the fit. Using this equation at $650{ }^{\circ} \mathrm{C}$ shows that the calcination time effect is bigger going from 1 to 2 hours ( 13 to $10 \mathrm{~m}^{2} / \mathrm{g}$ ) than from 2 to 3 hours $\left(10\right.$ to $\left.10 \mathrm{~m}^{2} / \mathrm{g}\right)$ as shown in Table $3-3$. However, as the calcination time increases further the predicted SSA value declines such that from 2 to 10 hours of calcination the predicted SSA drops from 10 to $8 \mathrm{~m}^{2} / \mathrm{g}$.

Table 3-2. Calcination Data $\left(550\right.$ to $\left.760{ }^{\circ} \mathrm{C}\right)$ of $\mathrm{Pu}\left(\mathrm{C}_{2} \mathrm{O}_{4}\right)_{2}$ to $\mathrm{PuO}_{2}$ for Regression of SSA

\begin{tabular}{|c|c|c|c|}
\hline TEMP $\left[{ }^{\circ} \mathrm{C}\right]$ & TIME $[\mathrm{h}]$ & SSA Observed $\left[\mathrm{m}^{2} / \mathrm{g}\right]$ & SSA Predicted $\left[\mathrm{m}^{2} / \mathrm{g}\right]$ \\
\hline 550 & 2.0 & 30.6 & 36 \\
\hline 550 & 2.0 & 41.1 & 36 \\
\hline 600 & 6 & 21 & 24 \\
\hline 600 & 3 & 27 & 23 \\
\hline 600 & 12 & 23.9 & 9 \\
\hline 650 & 4 & 4.93 & 9 \\
\hline 650 & 4 & 10.18 & 9 \\
\hline 650 & 4 & 9.76 & 9 \\
\hline 650 & 4 & 10.54 & 9 \\
\hline 650 & 4 & 10.86 & 9 \\
\hline 650 & 4 & 7.89 & 9 \\
\hline 650 & 4 & 8.47 & 9 \\
\hline 650 & 4 & 9.29 & 9 \\
\hline 650 & 4 & 8.64 & 9 \\
\hline 650 & 4 & 9.08 & 9 \\
\hline 650 & 4 & 8.30 & 9 \\
\hline 650 & 4 & 10.31 & 9 \\
\hline 650 & 4 & 10.23 & 9 \\
\hline 650 & 4 & 8.91 & 24 \\
\hline
\end{tabular}


Table 3-2. Calcination Data $\left(550\right.$ to $\left.760{ }^{\circ} \mathrm{C}\right)$ of $\mathrm{Pu}\left(\mathrm{C}_{2} \mathrm{O}_{4}\right)_{2}$ to $\mathrm{PuO}_{2}$ for Regression of SSA

\begin{tabular}{|c|c|c|c|}
\hline TEMP $\left[{ }^{\circ} \mathrm{C}\right]$ & TIME $[\mathrm{h}]$ & SSA Observed $\left[\mathrm{m}^{2} / \mathrm{g}\right]$ & SSA Predicted $\left[\mathrm{m}^{2} / \mathrm{g}\right]$ \\
\hline 650 & 4 & 13.56 & 9 \\
\hline 650 & 4 & 11.50 & 9 \\
\hline 650 & 4 & 10.37 & 9 \\
\hline 650 & 4 & 8.04 & 9 \\
\hline 650 & 4 & 9.07 & 9 \\
\hline 650 & 4 & 8.90 & 9 \\
\hline 650 & 4 & 10.54 & 9 \\
\hline 650 & 4 & 12.04 & 9 \\
\hline 650 & 4 & 13.51 & 9 \\
\hline 650 & 4 & 11.14 & 9 \\
\hline 650 & 4 & 8.35 & 9 \\
\hline 650 & 4 & 8.11 & 9 \\
\hline 650 & 4 & 9.82 & 9 \\
\hline 650 & 4 & 11.20 & 9 \\
\hline 650 & 4 & 6.85 & 9 \\
\hline 650 & 4 & 7.45 & 9 \\
\hline 650 & 4 & 7.70 & 9 \\
\hline 650 & 4 & 7.82 & 9 \\
\hline 650 & 4 & 8.11 & 9 \\
\hline 650 & 4 & 8.22 & 9 \\
\hline 650 & 4 & 7.87 & 9 \\
\hline 650 & 4 & 8.75 & 9 \\
\hline 650 & 4 & 9.01 & 9 \\
\hline 650 & 4 & 9.89 & 9 \\
\hline 650 & 4 & 9.07 & 9 \\
\hline 650 & 4 & 7.77 & 9 \\
\hline 650 & 4 & 8.19 & 9 \\
\hline 650 & 4 & 9.07 & 9 \\
\hline 650 & 4 & 9.37 & 9 \\
\hline 650 & 4 & 9.26 & 9 \\
\hline 650 & 4 & 14.86 & 9 \\
\hline 650 & $8.46^{*}$ & 7.9 & 9 \\
\hline 700 & $4.57^{*}$ & 9.48 & 7 \\
\hline 700 & $4.57^{*}$ & 10.83 & 7 \\
\hline 700 & 12 & 5.7 & 6 \\
\hline 735 & 2 & 4.2 & 7 \\
\hline 735 & 2 & 4.2 & 7 \\
\hline 735 & 2 & 4.5 & 7 \\
\hline 735 & 2 & 6.4 & 7 \\
\hline 735 & 2 & 7.3 & 7 \\
\hline 735 & 2 & 7.5 & 7 \\
\hline 735 & 2.0 & 9.1 & 7 \\
\hline 750 & $8 *$ & 2 & 2 \\
\hline 760 & 0.08 & 10.5 & 10 \\
\hline 760 & 0.28 & 7.5 & 9 \\
\hline
\end{tabular}


Table 3-2. Calcination Data $\left(550\right.$ to $\left.760{ }^{\circ} \mathrm{C}\right)$ of $\mathrm{Pu}\left(\mathrm{C}_{2} \mathrm{O}_{4}\right)_{2}$ to $\mathrm{PuO}_{2}$ for Regression of SSA

\begin{tabular}{|c|c|c|c|}
\hline TEMP $\left[{ }^{\circ} \mathrm{C}\right]$ & TIME $[\mathrm{h}]$ & SSA Observed $\left[\mathrm{m}^{2} / \mathrm{g}\right]$ & SSA Predicted $\left[\mathrm{m}^{2} / \mathrm{g}\right]$ \\
\hline 760 & 0.28 & 7.5 & 9 \\
\hline 760 & 0.28 & 9.11 & 9 \\
\hline 760 & 0.28 & 9.55 & 9 \\
\hline 760 & 0.28 & 9.94 & 6 \\
\hline 760 & 0.5 & 3.4 & 6 \\
\hline 760 & 0.5 & 3.4 & 6 \\
\hline 760 & 0.5 & 3.69 & 6 \\
\hline 760 & 0.5 & 3.99 & 6 \\
\hline 760 & 0.5 & 4.88 & 6 \\
\hline 760 & 0.5 & 5.4 & 6 \\
\hline 760 & 0.5 & 5.49 & 6 \\
\hline 760 & 0.5 & 5.83 & 6 \\
\hline 760 & 0.50 & 6.58 & 6 \\
\hline 760 & 0.50 & 7.15 & 6 \\
\hline 760 & 0.5 & 7.89 & 6 \\
\hline 760 & 0.5 & 8.3 & 3 \\
\hline 760 & 0.5 & 8.66 & \\
\hline 760 & 1.00 & 6.1 & 6 \\
\hline
\end{tabular}

Table 3-3. Predicted $\mathrm{SSA}$ values of $\mathrm{PuO}_{2}$ from $\mathrm{Pu}\left(\mathrm{C}_{2} \mathrm{O}_{4}\right)_{2}$ at Calcination Temperature $650{ }^{\circ} \mathrm{C}$ for various times

\begin{tabular}{|c|c|c|}
\hline TEMP $\left[{ }^{\circ} \mathrm{C}\right]$ & TIME $[\mathrm{h}]$ & $\begin{array}{c}\text { SSA } \\
\text { Predicted } \\
{\left[\mathrm{m}^{2} / \mathrm{g}\right]}\end{array}$ \\
\hline 650 & 1 & 13 \\
\hline 650 & 2 & 10 \\
\hline 650 & 3 & 10 \\
\hline 650 & 4 & 9 \\
\hline 650 & 5 & 9 \\
\hline 650 & 10 & 9 \\
\hline 650 & 12 & 8 \\
\hline
\end{tabular}




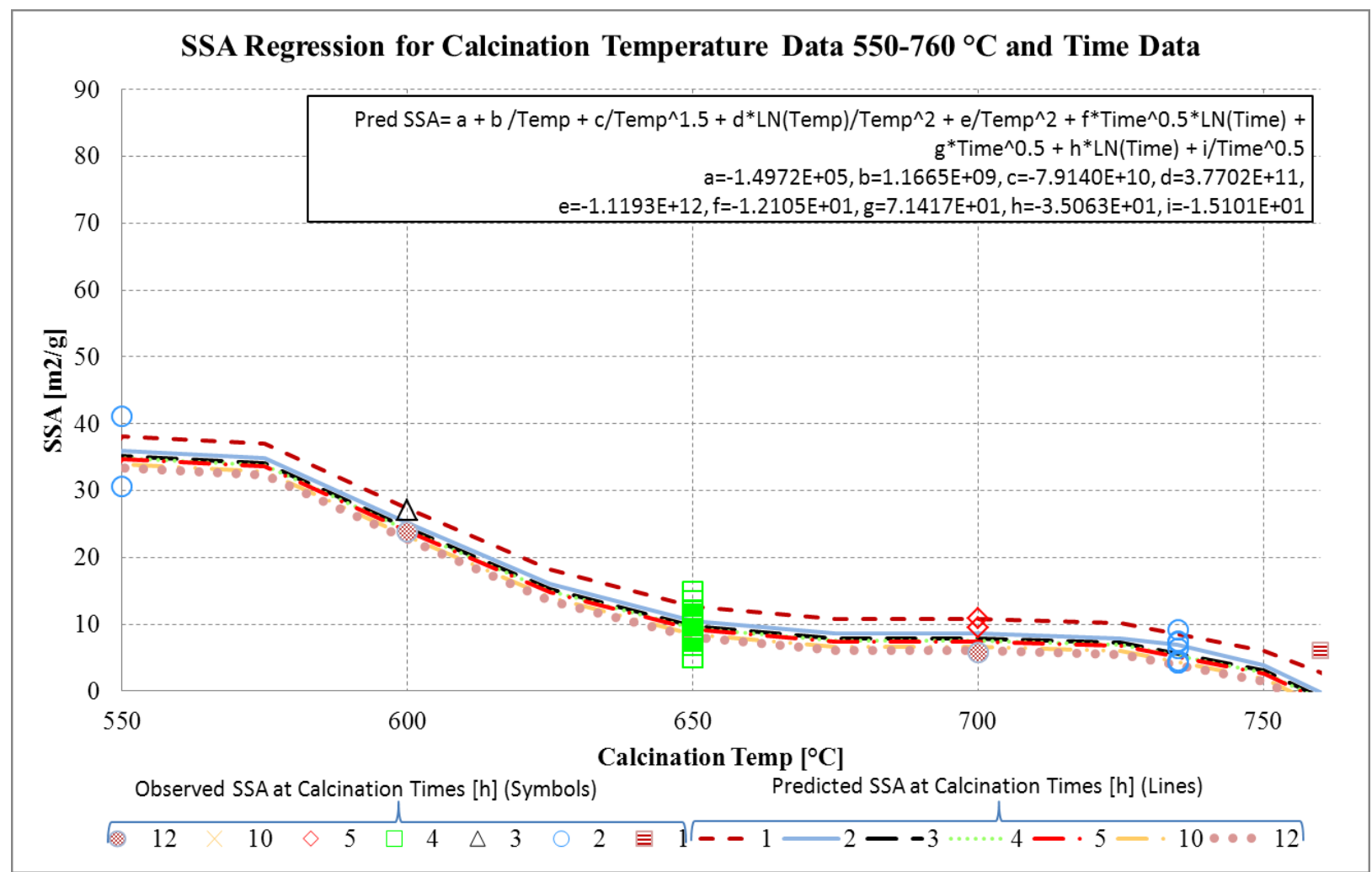

Figure 3-8. $\mathrm{PuO}_{2}$ from oxalate-Correlation of SSA to Calcination Temp. $\left(550-760{ }^{\circ} \mathrm{C}\right)$ and Time-2D View 1

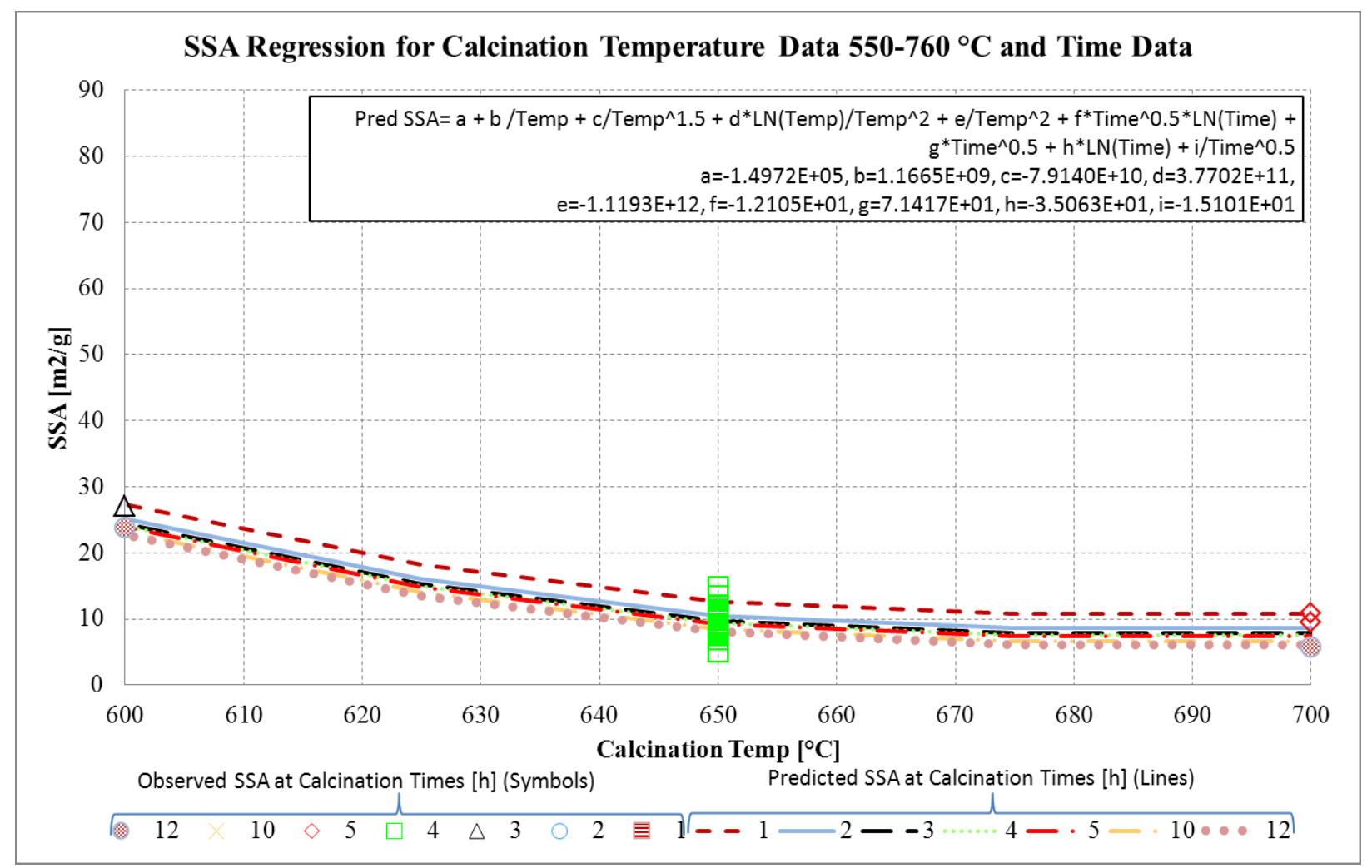

Figure 3-9. $\mathrm{PuO}_{2}$ from oxalate-Correlation of SSA to Calcination Temp. $\left(550-760{ }^{\circ} \mathrm{C}\right)$ and Time-2D View 2 
To help visualize the 3D fit of calcination temperature between 550 and $760{ }^{\circ} \mathrm{C}$ and time to the SSA data, the 3D plots from Table Curve 3D have been captured and pasted into this report.

Figure 3-3 through Figure 3-7 show the plots of the observed SSA values (the round data points in the figures) versus the empirical fit (the colored red/orange to blue surface) from Eqn 3-2.

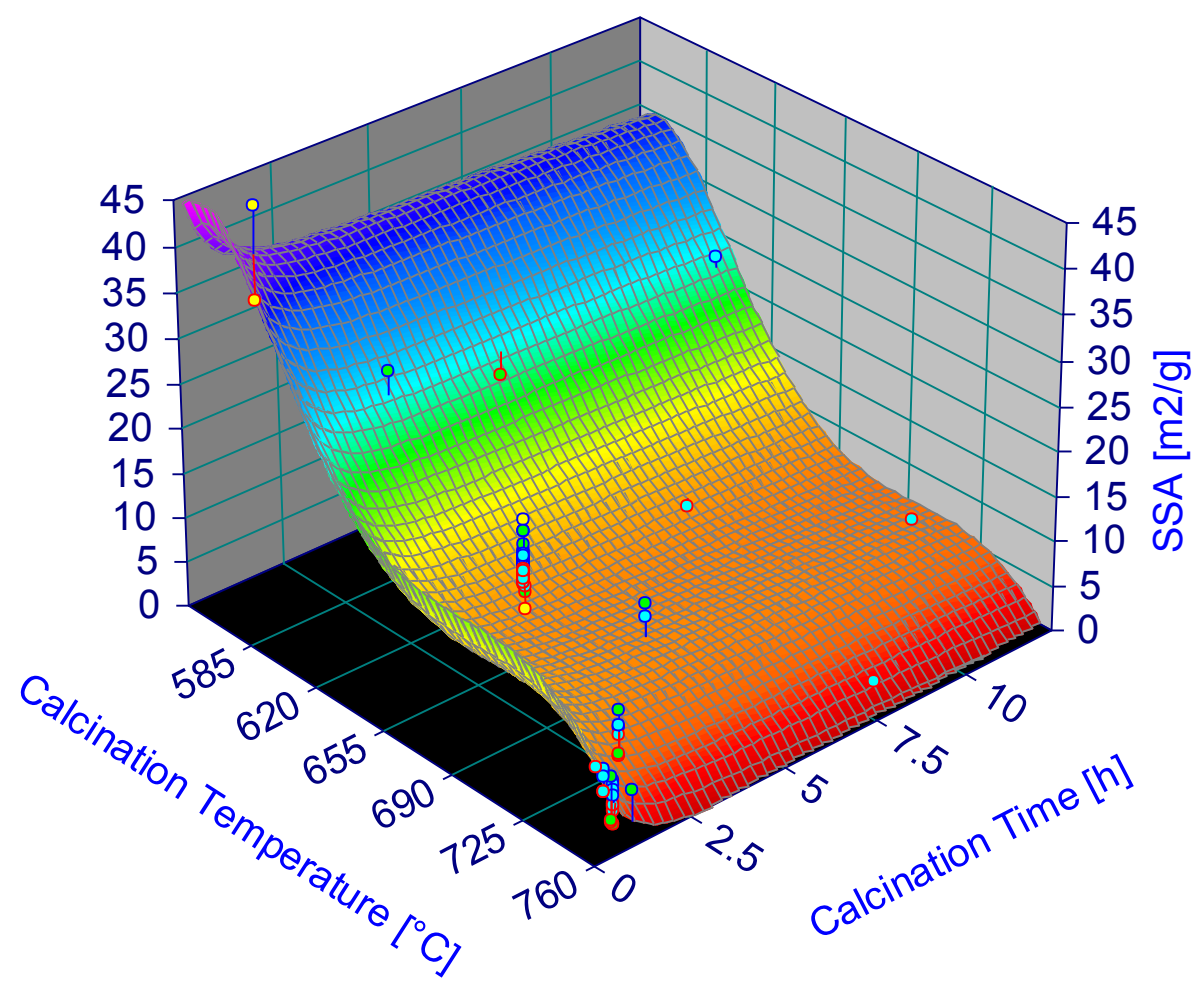

Figure 3-10. $\mathrm{PuO}_{2}$ from oxalate-Correlation of SSA to Calcination Temp. $\left(550-760{ }^{\circ} \mathrm{C}\right)$ and Time-3D View 1 


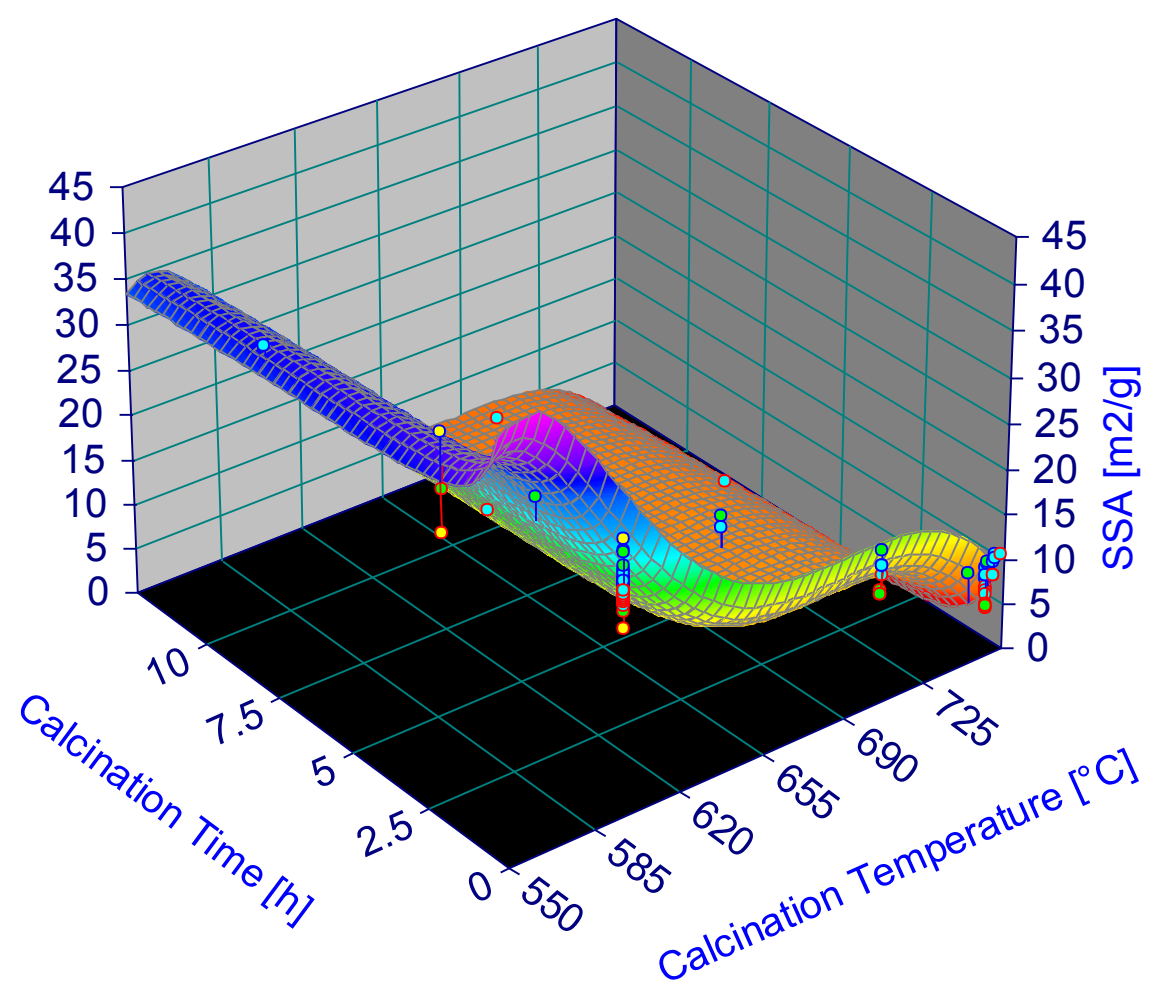

Figure 3-11. $\mathrm{PuO}_{2}$ from oxalate-Correlation of SSA to Calcination Temp. $\left(550-760^{\circ} \mathrm{C}\right)$ and Time-3D View 2

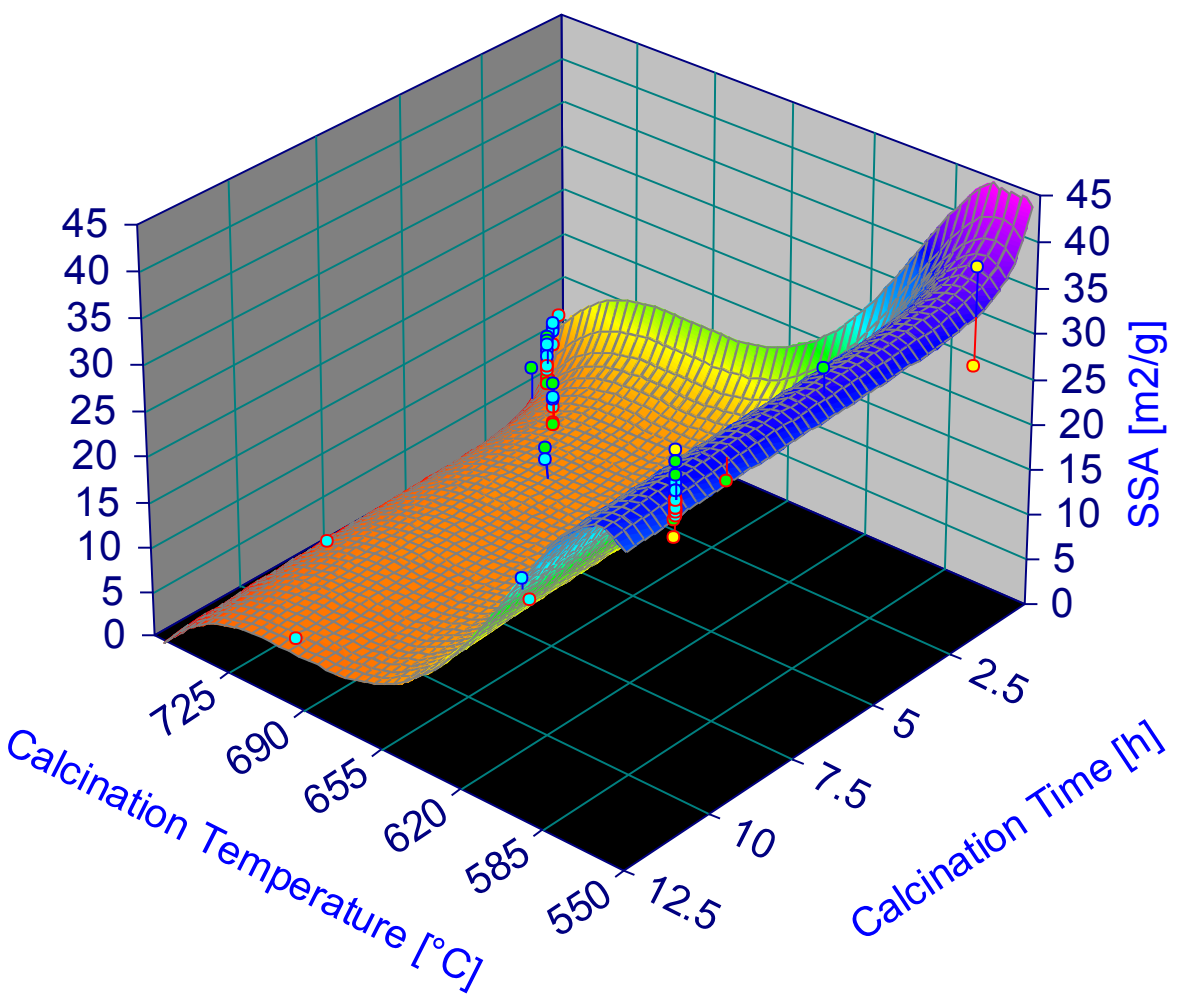

Figure 3-12. $\mathrm{PuO}_{2}$ from oxalate-Correlation of SSA to Calcination Temp. $\left(550-760{ }^{\circ} \mathrm{C}\right)$ and Time-3D View 3 


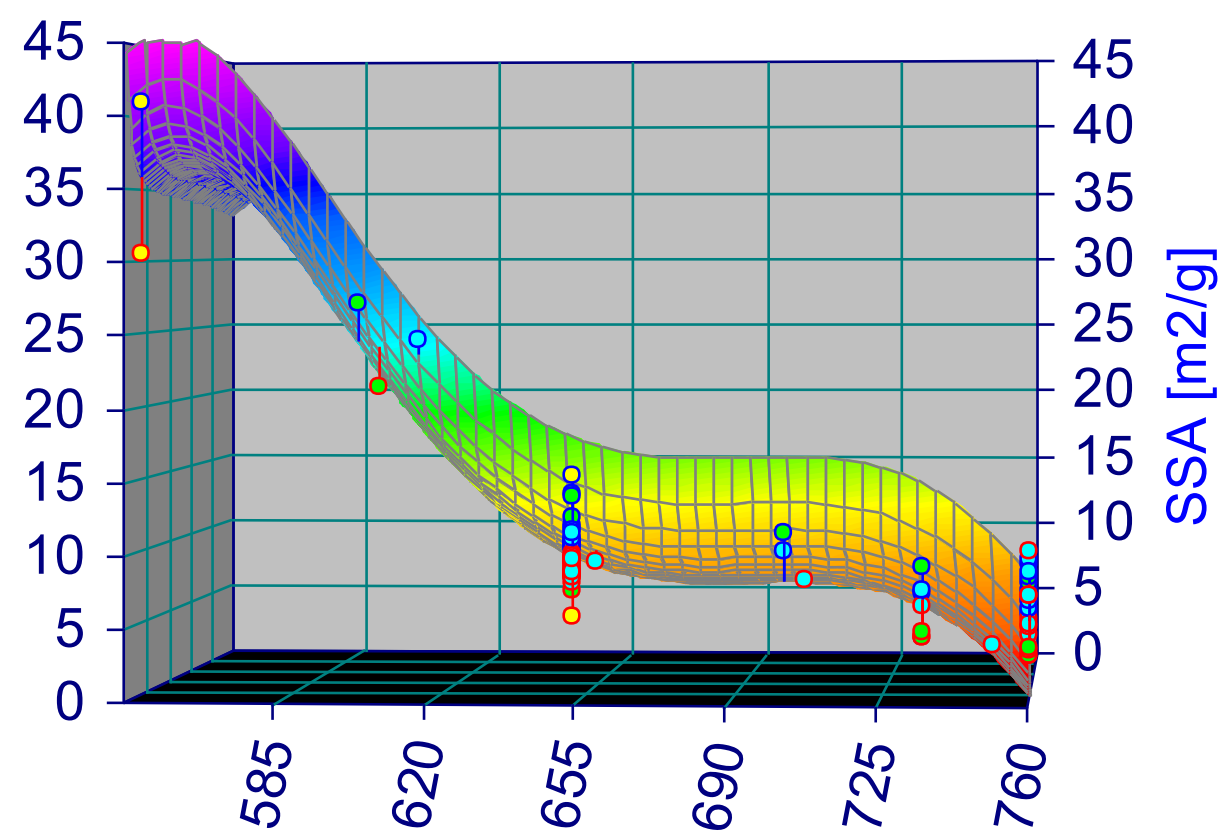

Calcination Temperature $\left[{ }^{\circ} \mathrm{C}\right]$

Figure 3-13. $\mathrm{PuO}_{2}$ from oxalate-Correlation of SSA to Calcination Temp. (550-760 $\left.{ }^{\circ} \mathrm{C}\right)$ and Time-3D View 4

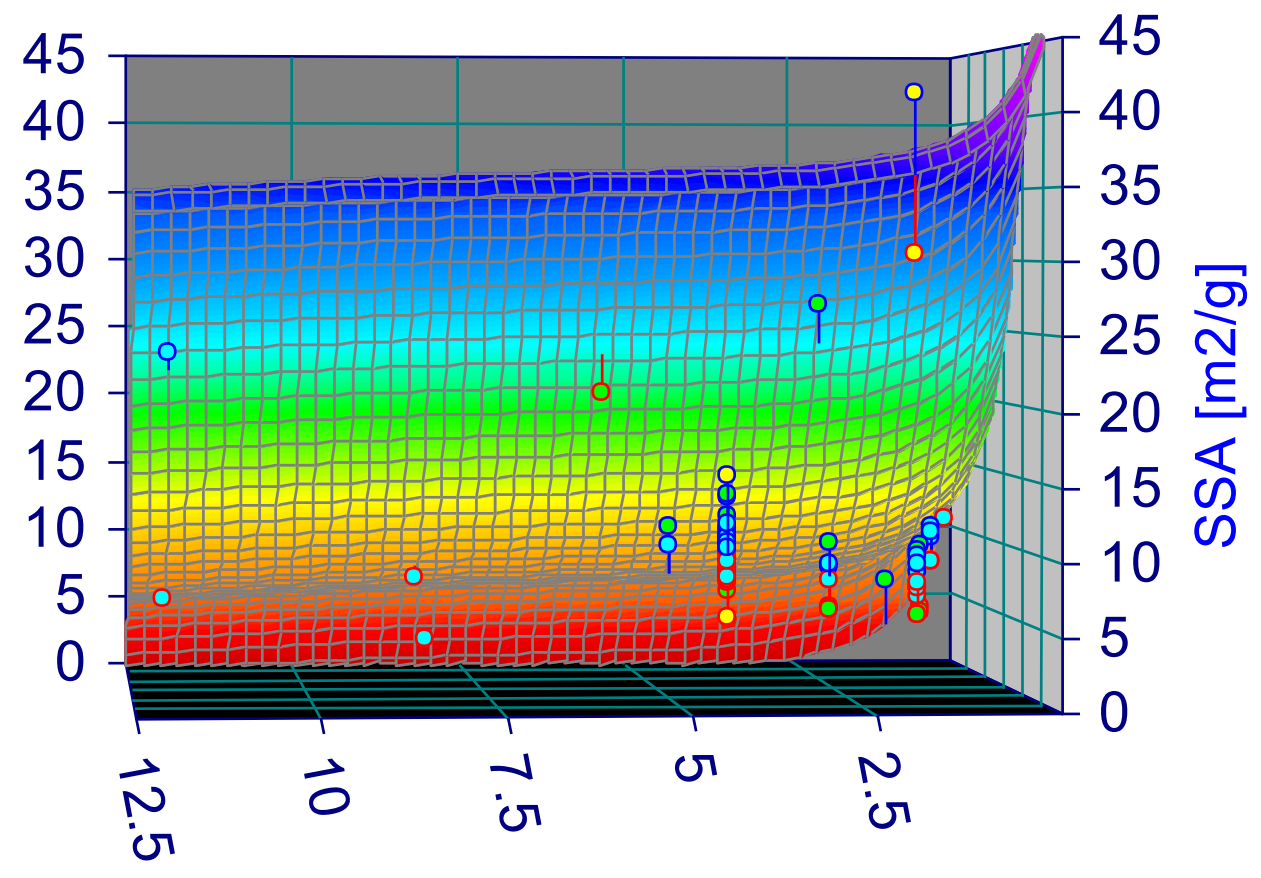

Calcination Time $[\mathrm{h}]$

Figure 3-14. $\mathrm{PuO}_{2}$ from oxalate-Correlation of SSA to Calcination Temp. $\left(550-760{ }^{\circ} \mathrm{C}\right)$ and Time-3D View 5 
SRNL-TR-2011-00334

Revision 0

\subsection{Conclusions}

The literature has been reviewed using multiple electronic databases searching for calcination data for plutonium oxide $\left(\mathrm{PuO}_{2}\right)$ from plutonium oxalate $\left(\mathrm{Pu}\left(\mathrm{C}_{2} \mathrm{O}_{4}\right)_{2}\right)$ with respect to its specific surface area (SSA). A summary of the literature has been presented for what are believed to be the dominant factors on SSA, the calcination temperature and time. The $\mathrm{PuO}_{2}$ from $\mathrm{Pu}\left(\mathrm{C}_{2} \mathrm{O}_{4}\right)_{2}$ calcination data from this literature review has been regressed to better understand the influence of calcination temperature and time on SSA. Based on this data set, calcination temperature has the bigger impact on SSA versus time. However, there is still some variance in this literature review data set that may be reflecting differences in plutonium oxalate preparation or different calcination techniques.

\subsection{Recommendations}

It is evident from this review that more calcination temperature and time data for plutonium oxide $\left(\mathrm{PuO}_{2}\right)$ from plutonium oxalate $\left(\mathrm{Pu}\left(\mathrm{C}_{2} \mathrm{O}_{4}\right)_{2}\right)$ needs to be collected and evaluated to better define the relationship. This literature data has a lot of calcination times around 2 hours and therefore may be underestimating the impact of calcination time on SSA. It is suggested that more calcination temperature and time data for $\mathrm{PuO}_{2}$ from $\mathrm{Pu}\left(\mathrm{C}_{2} \mathrm{O}_{4}\right)_{2}$ be collected in the specific temperature range of current interest $\left(600\right.$ to $650{ }^{\circ} \mathrm{C}$ ) for various calcination times ( 2 to 5 hours). From an empirical fit point of view, three calcination temperatures each at three different calcination times in the range of interest would improve the fit and better refine the relationship between the $\mathrm{SSA}$ of $\mathrm{PuO}_{2}$ from $\mathrm{Pu}\left(\mathrm{C}_{2} \mathrm{O}_{4}\right)_{2}$ and the calcination parameters. 
SRNL-TR-2011-00334

Revision 0

\subsection{References}

1. Machuron-Mandard, Xavier, Charles Madic, "Plutonium Dioxide Particle Properties As A Function Of Calcination Temperature," Journal of Alloys and Compounds, 235, 1996, p. 216-224.

2. Haschke, John M., Thomas E. Ricketts, "Adsorption of water on plutonium dioxide," Journal of Alloys and Compounds, 252, 1997, p. 148-156.

3. Haschke, John M., Thomas E. Ricketts," PuO2 Storage: Conditions for Preparation and Handling," LA-12999-MS, August 1995, Los Alamos National Laboratory, Los Alamos, New Mexico.

4. Caldwell, C. S., "Development of Plutonium Bearing Fuel Materials NUMEC P-80," NUMEC P-80, September 30, 1961, Nuclear Material and Equipment Corporation, Apollo, Pennsylvania.

5. Caldwell, C. S., O. Menis, "Development of Plutonium Bearing Fuel Materials NUMEC P-90,” NUMEC P-90, December 31, 1961, Nuclear Material and Equipment Corporation, Apollo, Pennsylvania.

6. Livingston, Ronald R., Jonathan M. Duffey, "Effects of Plutonium Dioxide Moisture Content and Calcination Temperature on the Headspace Gas Composition of Sealed Containers," WSRC-TR-2001-00420, Revision 0, September 2001, Westinghouse Savannah River Company, Savannah River Technology Center, Aiken, SC.

7. Alwin, Jennifer Louise, Fawn Coriz, Jan A. Danis, Brian K. Bluhm, David W. Wayne, Devin W. Gray, Kevin B. Ramsey, David A. Costa, Elizabeth A. Bluhm, Archie E. Nixon, "Plutonium Oxide Polishing for MOX Fuel Fabrication," Journal of Alloys and Compounds, 444-445, April 13, 2007, p. 565-568.

8. Smith, P. K., G. A. Burney, D. T. Rankin, D. F. Bickford, and R. D. Sisson, Jr., "Effect Of Oxalate Precipitation On Puo2 Microstructures," DP-MS-76-34, August 27, 1976, Savannah River Laboratory, E. I. du Pont de Nemours and Co., Aiken, SC.

9. Paffett, M.T., Dan Kelly, S.A. Joyce, John Morris, Kirk Veirs, “A Critical Examination of the Thermodynamics of Water Adsorption on Actinide Oxide Surfaces," Journal of Nuclear Materials, 322, 2003, p. 45-56.

10. Biancheria, A., Go Ehrlich, E. Garcia, J. Goodman, R . Jaroszeski, "Development of Plutonium Bearing Fuel Materials NUMEC P-100," NUMEC P-100, March 31, 1962, Nuclear Material and Equipment Corporation Apollo, Pennsylvania.

11. Hayun, Shmuel, Tatiana Y. Shvareva, and Alexandra Navrotsky, "Nanoceria Energetics of Surfaces, Interfaces and Water Adsorption," Journal of American Ceramic Society, 94, 2011, p. 3992-3999.

12. Veirs, D. K. , R. Mason, R. Erickson, "Technical Basis for Packaging Glovebox Moisture Content," LA-UR-02-560, Los Alamos National Laboratory, Los Alamos, New Mexico.

13. D. Kirk Veirs, "Gas generation from water adsorbed onto pure plutonium dioxide powder," Materials Research Society Symposium, 893, 2006.

14. Duffey, Jonathan M., Ronald R. Livingston, "Gas Generation Testing of Plutonium Dioxide,” WSRC-MS-2002-00705, 2002, Westinghouse Savannah River Company, Savannah River Technology Center, Aiken, SC. 
15. Hill, Benjamin C., Ronald R. Livingston, "Effect of Precipitation Conditions on the Specific Surface Area of Neptunium Oxide (U),” WSRC-TR-2004-00296, 2004, Westinghouse Savannah River Company, Savannah River National Laboratory, Aiken, SC.

16. Bluhm, Elizabeth A., Kent D. Abney, Simon Balkey, Jason C. Brock, Fawn Coriz, James T. Dyke, Daniel J. Garcia, Brenda J. Griego, Benjie T. Martinez, David Martinez, Joe Ray Martinez, "Plutonium Oxide Polishing for MOX Fuel Production," Separation Science \& Technology, 40, 2005, p. 281-296.

17. Jurgensen, A. R., D. M. Missimer, R. L. Rutherford, "Surface Area (BET) and TGA-MS Analysis of Calcined Neptunium Oxide (U)," WSRC-TR-2003-00378, REV. 0, 2003, Westinghouse Savannah River Company, Savannah River National Laboratory, Aiken, SC.

18. Crowder, Mark L., Jonathan M. Duffey, Ronald R. Livingston, John H. Scogin, Glen F. Kessinger, Philip M. Almond, "Moisture and Surface Area Measurements of Plutonium-Bearing Oxides," Journal of Alloys and Compounds, 488, 2009, p. 565-567.

19. Smith, D. M. , M. P. Neu, E. Garcia, L. A. Morales, "Hydration of Plutonium Oxide and Process Salts, $\mathrm{NaCl}, \mathrm{KCl}, \mathrm{CaCl}$, $\mathrm{MgCl}$," Waste Management 20, 20, 2000, p. 479-490.

20. Haschke, John M., "Thermodynamics of Water Sorption on PuO2: Consequences for Oxide Storage and Solubility," Journal of Nuclear Materials, 344, 2005, p. 8-12.

21. Farr, J. Douglas, Roland K. Schulze, Mary P. Neu, "Surface Chemistry of Pu Oxides," Journal of Nuclear Materials, 328, 2004, p. 124-136.

22. Necka, V., M. Altmaier, Th. Fanghanel, "Thermodynamic Data for Hydrous and Anhydrous $\mathrm{PuO}_{2+\mathrm{x}}(\mathrm{s})$," Journal of Alloys and Compounds, 444-445, 2007, p. 464469.

23. Minamoto, Satoshi, Masato Kato, Kenji Konashi, Yoshiyuki Kawazoe, "Calculations of Thermodynamic Properties of PuO2 by the First-Principles and Lattice Vibration," Journal of Nuclear Material, 385, 2009, p. 18-20.

24. Guéneau, Christine, Christian Chatillon, Bo Sundman, "Thermodynamic modeling of the plutonium-oxygen system," Journal of Nuclear Material, 378, 2008, p. 257272.

25. Haschke, John M ., Ted Venetz, Rich Szempruch, James W. McCZard, "White Paper on Possible Inclusion of Mixed Plutonium-Uranium Oxides in DOE-STD3013-96," LA-13236-MS, 1997, Los Alamos National Laboratory, Los Alamos, New Mexico.

26. Smith, Paul H. , Joshua E. Narlesky, Laura A. Worl, Obie W. Gillispie, "Characterization of Representative Materials in Support of Safe, Long Term Storage of Surplus Plutonium in DOE-STD-3013 Containers," LA-UR-10-04193, 2010, Los Alamos National Laboratory, Los Alamos, New Mexico.

27. Greinetz, R. M., D. H. Neal, "Plutonium(IV) Oxalate Precipitation and Calcination Process or Plutonium Nitrate to Oxide Conversion,” RFP-2602, 1978, Rockwell International, Atomics International Division, Rocky Flats Plant, Golden, Colorado. 
28. Travis, J. E., "Monthly Report Hanford Atomic Products Operation," HW-41205, 2/24/56, General Electric Company, Richland, Washington.

29. "Savannah River Laboratory Monthly Report, ${ }^{238}$ Pu Fuel Form Processes," DPST73-128-7, July 1973, E. I . du Pont de Nemours \& Co., Savannah River Laboratory, Aiken, SC.

30. Moseley, J . D. , R. O. Wing, "Properties of Plutonium Dioxide," RFP-503, August 24, 1965, DOW Chemical Company, Rocky Flats Plant, Golden, Colorado.

31. Greinetz, R. M., D. H. Neal, "Plutonium(III) Oxalate Precipitation and Calcination Process for Plutonium Nitrate to Oxide Conversion,” RFP-2603, February 1, 1980, Rockwell International, Energy Systems Group, Rocky Flats Plant, Golden, Colorado.

32. Hoyt, Richard C., Don G. Bouse, John D. Ludowise, "Interim Report on Plutonium Oxalate Precipitation Work," SD-CP-TI-014, June 1983, Rockwell International, Energy Systems Group, Rocky Flats Plant, Golden, Colorado.

33. Hoyt, R. C., "Control of Particle Size and Structure," Defense Program Planning Presentation, July 1988, Westinghouse Hanford Company, Richland, Washington.

34. Jenkins, I. L., M. J. Waterman, "The Thermal Decomposition of Hydrated Plutonium(IV) Oxalates," Journal Inorganic Nuclear Chemistry, 26, 1964, p. 131137.

35. Porter, J. A., A. E. Symonds, Jr., "Precipitation of Plutonium(III) Oxalate and Calcination to Plutonium Dioxide," DP-981, November 1965, Dupont, Savannah River Laboratory, Aiken, SC.

36. Myers, M. N., "Precipitation of Plutonium(III) Oxalate and Calcination to Plutonium Dioxide," HW-45128, August 1, 1956, General Electric Company, Richland, Washington.

37. Rao, G. S., Subramanian, G.A. Welch, "Thermal Decomposition of Plutonium Oxalates," Journal Inorganic Nuclear Chemistry, 25, 1963, p. 1293-1300.

38. Stakebake, J. L., "Determination of Plutonium Dioxide Surface Areas from X-Ray Crystallite Sizes," Journal of Catalysis, 78, 1982, p. 477-481.

39. Puechl, Karl H., "Development of Plutonium-Bearing Fuel Materials, NUMEC2389-2," NUMEC-2389-2, February 10, 1964, Nuclear Materials and Equipment Corporation, Apollo, Pennsylvania.

40. Puechl, Karl H., "Development of Plutonium-Bearing Fuel Materials, NUMEC2389-3,", NUMEC-2389-3, March 10, 1964, Nuclear Materials and Equipment Corporation, Apollo, Pennsylvania.

41. Puechl, Karl H., I. D. Thomas, "Development of Plutonium-Bearing Fuel Materials, NUMEC-2389-4," NUMEC-2389-4, March 31, 1964, Nuclear Materials and Equipment Corporation, Apollo, Pennsylvania.

42. Puechl, Karl H., I. D. Thomas, William J. Ross, "Irradiation Testing of $\mathrm{UO}_{2}-\mathrm{PuO}_{2}$ Fuels, NUMEC-3432-6," NUMEC-3432-6, December 31, 1964, Nuclear Materials and Equipment Corporation, Apollo, Pennsylvania.

43. Puechl, Karl H., M. J. Garber, R. J. Atkins, L. J. Jones, "Development of Plutonium-Bearing Fuel Materials, NUMEC-P-20,” NUMEC-P-20, March 31, 1960, Nuclear Materials and Equipment Corporation, Apollo, Pennsylvania. 
44. Puechl, Karl H., M. J. Garber, R. J. Atkins, L. J. Jones, "Development of Plutonium-Bearing Fuel Materials, NUMEC-P-34," NUMEC-P-34, September 5, 1961, Nuclear Materials and Equipment Corporation, Apollo, Pennsylvania.

45. Puechl, Karl H., "Development of Plutonium-Bearing Fuel Materials, NUMEC-P37,’ NUMEC-P-37, February 5, 1962, Nuclear Materials and Equipment Corporation, Apollo, Pennsylvania.

46. Puechl, Karl H., "Development of Plutonium-Bearing Fuel Materials, NUMEC-P39," NUMEC-P-39, March 5, 1962, Nuclear Materials and Equipment Corporation, Apollo, Pennsylvania.

47. Puechl, Karl H., M. J. Garber, R. J. Atkins, "Development of Plutonium-Bearing Fuel Materials, NUMEC-P-40,” NUMEC-P-40, September 30, 1960, Nuclear Materials and Equipment Corporation, Apollo, Pennsylvania.

48. Puechl, Karl H., "Development of Plutonium-Bearing Fuel Materials, NUMEC-P44,” NUMEC-P-44, August 5, 1962, Nuclear Materials and Equipment Corporation, Apollo, Pennsylvania.

49. Puechl, Karl H., M. J. Garber, R. J. Atkins , "Development of Plutonium-Bearing Fuel Materials, NUMEC-P-60,” NUMEC-P-60, March 31, 1961, Nuclear Materials and Equipment Corporation, Apollo, Pennsylvania.

50. Puechl, Karl H., M. J. Garber, "Development of Plutonium-Bearing Fuel Materials, NUMEC-P-70,” NUMEC-P-70, June 30, 1961, Nuclear Materials and Equipment Corporation, Apollo, Pennsylvania.

51. Puechl, Karl H., M. J. Garber, "Development of Plutonium-Bearing Fuel Materials, NUMEC-P-101,” NUMEC-P-101, June 30, 1962, Nuclear Materials and Equipment Corporation, Apollo, Pennsylvania.

52. Puechl, Karl H., "Development of Plutonium-Bearing Fuel Materials, NUMEC-P102," NUMEC-P-102, September 30, 1962, Nuclear Materials and Equipment Corporation, Apollo, Pennsylvania.

53. Puechl, Karl H., "Development of Plutonium-Bearing Fuel Materials, NUMEC-P103,” NUMEC-P-103, December 31, 1962, Nuclear Materials and Equipment Corporation, Apollo, Pennsylvania.

54. Puechl, Karl H., "Development of Plutonium-Bearing Fuel Materials, NUMEC-P104,” NUMEC-P-104, March 31, 1963, Nuclear Materials and Equipment Corporation, Apollo, Pennsylvania.

55. Puechl, Karl H., "Development of Plutonium-Bearing Fuel Materials, NUMEC-P105,” NUMEC-P-105, June 30, 1963, Nuclear Materials and Equipment Corporation, Apollo, Pennsylvania.

56. Puechl, Karl H., "Development of Plutonium-Bearing Fuel Materials, NUMEC-P106,” NUMEC-P-106, September 30, 1963, Nuclear Materials and Equipment Corporation, Apollo, Pennsylvania.

57. O.R.H. Rasmussen, "Ceramic properties of PuO2," US DOE Report, ARH-1153, March 1969, Atlantic Richfield Hanford Company, Richland, WA.

58. "Savannah River Laboratory Monthly Report: Pu-238 Fuel Form Process," DPST75-128-3," March 1975, DuPont, Savannah River Laboratory, Aiken, SC. 


\section{Distribution:}
A. B. Barnes, 999-W
W. E. Harris, 704-2H
S. D. Fink, 773-A
J. B. Schaade, 704-2H
B. J. Giddings, 786-5A
G. J. Zachman, 225-7H
C. C. Herman, 999-W
P. B. Andrews, 704-2H
S. L. Marra, 773-A
S. J. Howell, 221-H
W. R. Wilmarth, 773-A
J. M. Duffey, 773-A
K. P. Burrows, 704-2H
M. L. Crowder, 773-A
J. W. Christopher, 704-2H
E. A. Kyser, 773-A
K. J. Gallahue, 221-H
C. A. Nash, 773-42A
J. E. Therrell, 704-2H

R. R. Livingston, 730-2B

D. Stimac, 730-2B

S. A. Thomas, DOE-SR, 703-46A 